\title{
Den visuella bilden av organisationen Perspektiv på visualitet i accounting Emelie Havemo
}




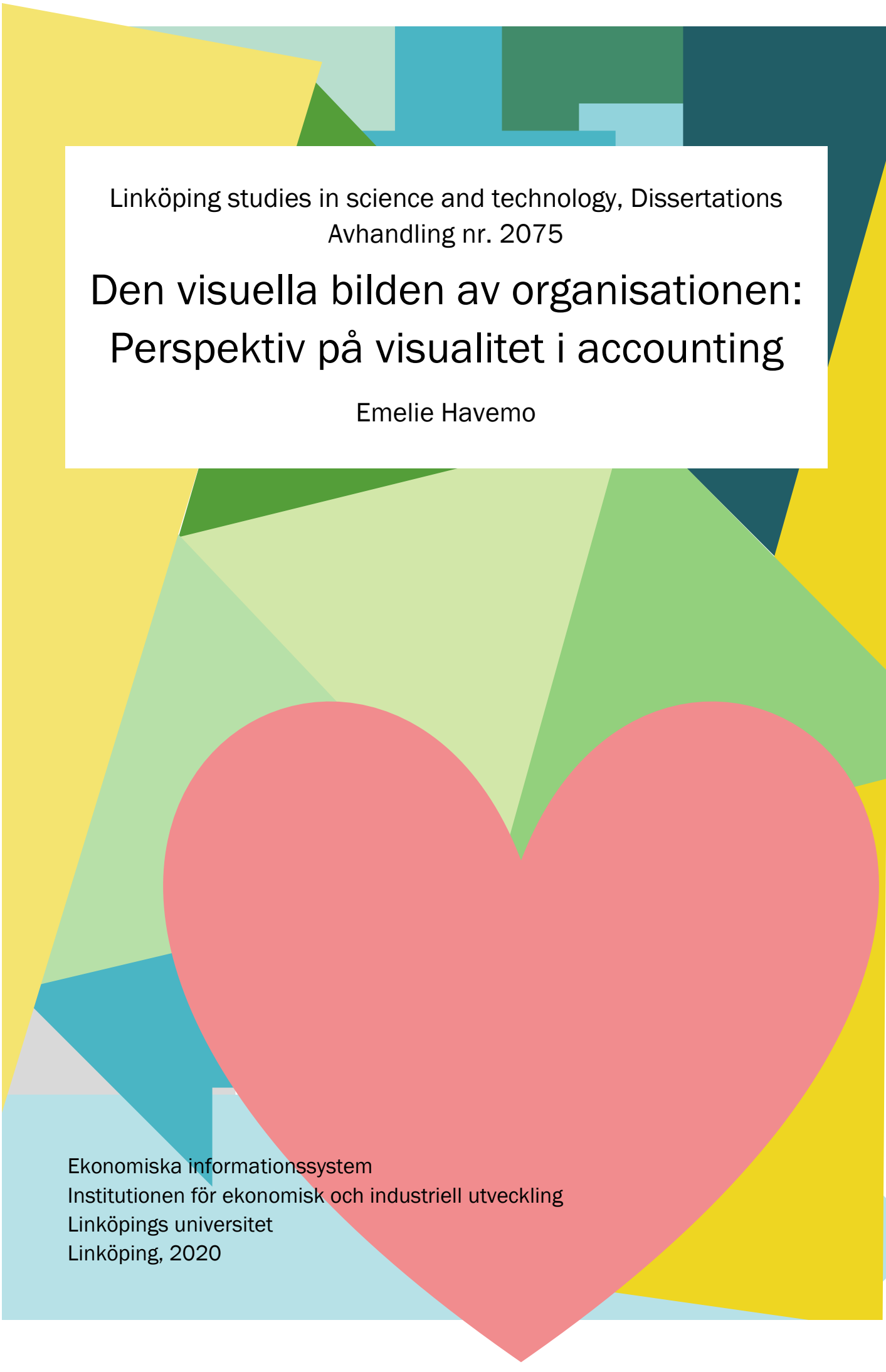


Den visuella bilden av organisationen: Perspektiv på visualitet i accounting (c) Emelie Havemo 2020, om inget annat anges

Linköping studies in science and technology, Dissertations Avhandling nr. 2075

ISSN 0345-7524

ISBN 978-91-7929-843-2

Omslagsfoto: "Bönräknare" av Emelie Havemo

Tryckt av LiU-Tryck, Linköping

Distribuerad av Linköpings universitet Institutionen för ekonomisk och industriell utveckling 58183 Linköping 


\title{
Five essays on visuality in accounting
}

\author{
by \\ Emelie Havemo \\ Linköping, June 2020 \\ Linköping studies in science and technology \\ Dissertation No. 2075
}

ISBN 978-91-7929-843-2

ISSN 0345-7524

Organisations play a crucial role as actors that shape material action and societal discourse; therefore, it is important to understand the ways in which they gain legitimacy and how they shape society. The power of accounting representations to construct the accounting object - the organisation - is therefore a key concern in the accounting literature. Accounting is widely treated as a numbers-based 'language of business' through which 'paper world' representations shape outcomes in the material world. At present, visuality (the presence of visual images and visual thinking) is gaining influence as a means to represent organisations and construct accounting objects visually. As visuality continues to expand into the realm of accounting, questions emerge about its role and the possibilities of combining the two 'languages' during a time when management research is facing a "visual turn".

The purpose of this dissertation is to explore the nature of visuality in accounting. The dissertation is based on five essays that contribute to the visual turn through semiotic analysis of visual texts and qualitative case studies. Paper I explores how business model diagrams - an example of a corporate selfrepresentation - can be designed, and proposes a typology of four main logics for illustrating value creation: classification, circularity, processes and transactions. Paper II describes the development of visuals use in the annual report, finding that visuals are used in greater numbers overall, and that diagrams are a relatively new visual resource in financial reporting. The paper also outlines the trend of amateriality, that is, that visuals increasingly refer to a non-specific and symbolbased idea of the organisation. In Paper III, internal and external representations of a business model are compared, and I conclude that self-representations can be based on parallel but conflicting interpretations of an idea. Paper IV proposes a new visual method for analysing combinations of graphs and texts, and shows that the 'rhythm' of graph use in the annual report increasingly integrates visuality in accounting narratives so that accounting and visuality overlap. Finally, Paper $\mathrm{V}$ 
explores challenges and opportunities of a digitalisation of visual artefacts based on the experiences of three organisations that used visual management before the transition.

The theoretical contribution of this dissertation is framed in terms of two perspectives. First, a developmental perspective highlights that the nature of visuality has become more prominent in accounting settings, and that the nature of visuality has changed from materiality-based to amaterial practices that favour conceptual visualisations like diagrams and visual symbols. Second, visuality is explored from an 'overlaps' perspective. Three explanations for the role of visuality in accounting are synthesised from the literature: separation, convergence and multilingualism. The contribution is to conceptualise these 'overlap models' and thereby deepen the understanding of the role played by visuality in accounting. I also propose a fourth model - bridging - to extend the range of explanations for the meaning of a visual form of accounting.

Based on the findings that visuality is more prominent and that the role of visuality is changing, it is proposed visual literacy is an important skill for practitioners who use visual images in accounting. The dissertation presents two frameworks that can contribute to visual literacy. The "transformationality framework' shows how to analyse underlying ideas in corporate diagrams, and the 'rhythm framework' illustrates how to shape, use and analyse accounting texts in terms of how combinations of visuals form different rhythms in the annual report.

Key words: visuality, accounting, semiotics, visual management, financial reporting

Economic Information Systems Department of Management and Engineering

Linköping University

Linköping, June 2020 


\section{SAMMANFATTNING}

Organisationer spelar en avgörande roll som aktörer i dagens samhälle, och påverkar såväl den materiella världen som våra gemensamma uppfattningar om den. Här har redovisningen en viktig roll att spela eftersom den ofta beskrivs som det "ekonomiska språket" (på engelska "the language of business") och därmed har makt att konstruera uppfattningar om världen - i redovisningstermer. Det pågår en utveckling där det visuella spelar en allt större roll i detta konstruerande, vilket ger upphov till överlappning mellan den historiskt sett sifferbaserade redovisningen, och det visuella, vilket kan ses som två olika språk som möts. Utvecklingen att "visualiteten" spelar allt större roll i organisationer kallas ibland "the visual turn" (den visuella vändningen), och det är till denna strömning som avhandlingens resultat bidrar genom att utforska perspektiv på visualitet i redovisningen.

Syftet med avhandlingen är att utforska visuella bilder av organisationer för att föreslå sätt att förstå visualitet i redovisningssammanhang, det vill säga i ekonomistyrning, redovisning och finansiell rapportering. Avhandlingen bygger på fem vetenskapliga artiklar som använder metoderna semiotisk analys och kvalitativa fallstudier. Artikel I undersöker hur affärsmodellsdiagram, ett exempel på ett konceptuellt "självporträtt" av organisationen - en visuell bild - kan utformas, och föreslår en typologi med fyra sätt att illustrera värdeskapande: som byggstenar, transaktioner, processer eller som en cykel. Artikel II beskriver hur bildanvändning i Ericssons årsredovisningar utvecklats mellan 1947 och 2016. Analysen visar att bildanvändningen gått mot en "amaterialisering", det vill säga att bilderna i ökande grad visualiserar en icke-specifik och symbolbaserad bild av organisationen. I Artikel III undersöks interna och externa beskrivningar av en affärsmodell - en mental bild - med slutsatsen att olika, ibland motsägande, självrepresentationer kan förekomma parallellt i samma organisation. Artikel IV föreslår en ny visuell metod för att undersöka informationssekvenser i årsredovisningar. Genom att analysera grafer visar jag att visualitet kan förstås som "rytmer" som bidrar till att skapa en bild av organisationers prestationer i redovisningssammanhang. Slutligen undersöker Artikel V visualitet i tre organisationer som använder leanbaserad styrning, som är ett visuellt styrparadigm. Artikeln beskriver utmaningar de ställs inför i samband med införandet av nya digitala versioner av det visuella styrverktyget pulstavlor.

Det teoretiska bidraget i avhandlingen formuleras utifrån två perspektiv. För det första visar utvecklingsperspektivet att visualiteten överlag fått en mer framträdande roll i redovisningen, samt att denna roll kommit att baseras alltmer 
på amaterialitet när det gäller att konstruera bilden av organisationen. För det andra används överlappningsperspektivet för att undersöka sätt att förklara visualitetens roll i redovisningen. Tre förklaringsmodeller för visualitet sammanställs och diskuteras utifrån företagsekonomisk litteratur: separation, konvergens och flerspråkighet. Dessutom föreslås en fjärde modell - länkning - för att bredda förståelsen av visualitet.

Eftersom visualiteten visas spela en större, och delvis förändrad, roll i redovisningen föreslås att visuell läskunnighet är en viktig förmåga för personer som interagerar med redovisningsinformation. Avhandlingen lägger fram två ramverk som kan bidra till visuell läskunnighet. Typologin av affärsmodeller från Artikel I och den tillhörande idén att diagram visar olika grad av förändring (transformationalitet) föreslås kunna användas för att designa bättre affärsmodeller, och den visuella metoden för att "se" bildanvändning utifrån metaforen musikalisk rytm från Artikel IV, föreslås att användas för att tänka sekventiellt på formulering av budskap vid utformning och granskning av visuella bilder av organisationer.

Nyckelord: visualitet, redovisning, ekonomistyrning, semiotik, finansiell rapportering, visual management 


\section{FÖRETAL}

\section{Ekonomiska informationssystem}

Ämnesområdets huvudfokus är gränslandet mellan ekonomi och IT, inte minst i nya, snabbväxande, IT-intensiva verksamheter. Mer precist handlar ämnesområdet dels om hur information överförs från, mellan och till människor, dels om möjligheter och konsekvenser med digitalisering. Området inkluderar forskning om affärs- och verksamhetsutveckling, styrning, kunskaps- och kompetensutveckling, särskilt i verksamheter där IT-utnyttjande är en väsentlig beståndsdel.

Särskilt intresse riktas mot vilken roll strategier och informationssystem har när människor samverkar i olika slags organisationer (företag, myndigheter, förvaltningar och föreningar), nätverk och koalitioner, och mot samspelet med omgivande ekologier. Här är visualiseringar en intressant och växande företeelse. Perspectives management - att uppfatta och hantera olika intressenters perspektiv - är en väsentlig del i strävan att nå en djupare och mer nyanserad förståelse av de studerade företeelserna.

Inom ämnesområdet tillhör doktoranderna även forskarskolan Management och IT (MIT). I MIT medverkar ett dussin högskolor och universitet. Inom ramen för detta nätverk erbjuds en doktorandutbildning med inriktning på frågeställningar i gränslandet mellan ekonomi och IT.

Föreliggande arbete, Den visuella bilden av organisationen: Perspektiv på visualitet $i$ accounting, är skrivet av Emelie Havemo. Hon presenterar det som sin doktorsavhandling inom ämnesområdet Ekonomiska informationssystem, Institutionen för ekonomisk och industriell utveckling, Linköpings universitet.

Linköping i april 2020

Alf Westelius

Professor

Ekonomiska informationssystem 



\section{FÖRORD}

Jag har sedan länge glömt vad sammanhanget var, men när min pappa för många år sedan påpekade att "vägen är målet" - jag hade aldrig hört orden förut då det här var ett antal år sedan - så ändrades min syn på tillvaron mot mer fokus på nuet, och jag har sedan dess ofta återkommit till att fundera på olika vägars betydelser. Men om vägen nu är målet, vad är en färdig avhandling, som länge bara var ett avlägset mål? För att blanda metaforerna så är målet förhoppningsvis en dörr (inte en fallucka) till nya vägar framöver. Och när jag finner mig där så kan jag blicka tillbaka på vägen som denna avhandling utgjort med glädje och tacksamhet till de som varit med och som bidragit under resans gång:

Alf och Carl-Johan, mina handledare, har under doktorandtiden delat med sig av sina kunskaper, och har såväl utmanat som uppmuntrat mina idéer och hjälpt mig med allt från teoridiskussioner till instruktioner om skiljetecken. Er hjälp och ert stöd på vägen har varit ovärderligt. Jag vill också tacka Martin för alla förslag och kommentarer på förslutseminariet, de gav energi att jobba vidare och utveckla texten. Tack även till Magnus för input på ett tidigare utkast och tänkvärda inspel om den praktiska sidan.

Till mina kollegor på EIS, Nils-Göran, Markus, Margaret, Fredrik, Özgün och Susanne, vill jag rikta ett stort tack för alla samtal och lärorika diskussioner på seminarier och i fikarummet genom åren. Ett stort tack vill jag också rikta till kollegorna på Industriell ekonomi, med vilka man kan ägna sig åt såväl djupdykning i svåra vetenskapsfilosofiska och pedagogiska resonemang som att spåna fram diverse idéer och uppfinningar för att förbättra världen. Tack särskilt till Mojtaba för hjälp med statistiska analyser i Artikel I.

Under doktorandperioden har jag haft förmånen att ingå i, och delfinansieras av, den nationella forskarskolan MIT, Management och IT, som utgör ett doktorandnätverk med konferenser och kurser inom företagsekonomi och informatik. Genom detta nätverk har jag mött många olika forskningsfrågor och forskningsperspektiv, och ännu fler kunniga och engagerade doktorander och seniorer, och jag vill därför tacka forskarskolan och dess medlemmar för en lärorik och hjälpsam miljö att utveckla min forskning i.

Jag måste också rikta ett stort tack till de organisationer och personer jag träffat som berättat om sina erfarenheter om visualisering i organisationer. Tack för att ni bidragit med er tid och era erfarenheter och gjort forskningen möjlig! 
Slutligen vill jag tacka familj och vänner för att ni varit på olika sätt och gjort vägen så mycket trevligare att resa på, och tack Sara för vägledning i den grafiska världen!

Och framförallt tack till Roland som egentligen ville vara med på foto på omslaget tillsammans med katten Rocky. Jag har ritat av dig här till höger om det är någon tröst. Den här avhandlingen tillägnas dig.

Linköping i april 2020

Emelie Havemo

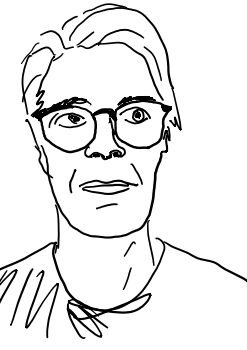

"Till Roland" 


\section{ARTIKLAR}

Detta är en sammanläggningsavhandling som inkluderar följande fem artiklar:

I Havemo, E. (2018) 'A visual perspective on value creation: Exploring patterns in business model diagrams'. European Management Journal, 36(4), s. 441-452.

II Havemo, E. (2018) 'Visual trends in the annual report: the case of Ericsson 1947-2016'. Corporate Communications: An International Journal, 23(3), s. 312-325.

III Havemo, E. (2019) 'Communicating the business model at a Swedish start-up: an interpretive study'. Journal of Business Models, 7(2), s.1430.

IV Havemo, E. 'Get rhythm!' (alternativ titel ${ }^{1}$ ) Under revision för en internationell tidskrift inom redovisning.

V Havemo, E. 'Do employees dream of digital boards?' (alternativ titel) Inskickad till en internationell tidskrift inom operations management.

Artiklarna identifieras utifrån sin titel eller romerska siffra i avhandlingen. Siffran anger kronologisk ordning på artiklarnas utveckling, med undantag för Artikel III som påbörjades först men färdigställdes efter Artikel I och II. Tidigare versioner av Artikel I-III ingår även i min licentiatavhandling, men har uppdaterats i samband med reviews och behandlas i avhandlingen ur nya perspektiv.

\section{Relaterade publikationer}

Eriksson, E. (2017). Patterns of corporate visual self-representation in accounting narratives. Linköping Studies in Science and Technology, Licentiatavhandling nr 1792. Linköpings universitet.

Havemo, E. (2019) 'Digitala tavlor: Erfarenheter av införande och användning av digitala leantavlor i tre svenska organisationer'. Rapporter från IEI, Institutionen för ekonomisk och industriell utveckling, LIU-IEI-RR-19/00332-SE.

\footnotetext{
${ }^{1}$ Artikel IV och Artikel V var vid tidpunkten för tryck i processer för anonym review och jag har därför gett dem andra alternativa titlar för att bevara författaranonymiteten i och med att avhandlingens kappa publiceras elektroniskt. Hela den nuvarande titeln anges dock i bilagan där artiklarna inkluderas.
} 



\section{INNEHÅLLSFÖRTECKNING}

Inledning 3

Visuella bilder av organisationer $\quad 5$

Visualitetens teoretiska relevans för redovisningsfältet 8

Syfte och utformning $\quad 11$

$\begin{array}{ll}\text { Perspektiv på visualitet i redovisningssammanhang } & 17\end{array}$

$\begin{array}{ll}\text { Tidigare litteratur om visualitet i redovisning } & 17\end{array}$

Visualitetens funktion $\quad 19$

Visualitetens roll i studier $\quad 22$

Visualitetens undersökningsnivåer $\quad 25$

Förklaringsmodeller för visualitetens roll i redovisningen 30

Utestående frågor om visualitet inom redovisning 36

$\begin{array}{ll}\text { Forskningsmetoder } & 41\end{array}$

Vetenskapligt förhållningssätt $\quad 41$

Reflektion om material och undersökningsmetoder 46

Studie 1 och 2: Semiotiska analyser $\quad 46$

Studie 3 och 4: Kvalitativa fallstudier 50

Reflektion om avhandlingens metoder i relation till bidragen 51

Presentation av artiklarna om visualitet i redovisning $\quad 55$

Artiklarna och deras bidrag till förståelsen av visualitet 56

I. A visual perspective on value creation 56

II. Visual trends in the annual report: the case of Ericsson $\quad 57$

III. Communicating the business model at a Swedish start-up 59

IV. Get rhythm! 60

V. Do employees dream of digital boards? 61

Artiklarnas bidrag till förståelsen av visualitet i redovisning 62

$\begin{array}{ll}\text { Slutsatser och bidrag } & 69\end{array}$

$\begin{array}{ll}\text { Utvecklingsperspektivet } & 70\end{array}$

$\begin{array}{ll}\text { Överlappningsperspektivet } & 72 \\ \end{array}$

$\begin{array}{ll}\text { Praktiska bidrag } & 76\end{array}$

Ramverk för visuell läskunnighet $\quad 76$

Tillämpning och utveckling av visuella metoder som metodbidrag $\quad 77$

$\begin{array}{ll}\text { Källförteckning } & 79\end{array}$

$\begin{array}{ll}\text { Bilaga: Artikel I-V } & 89\end{array}$ 



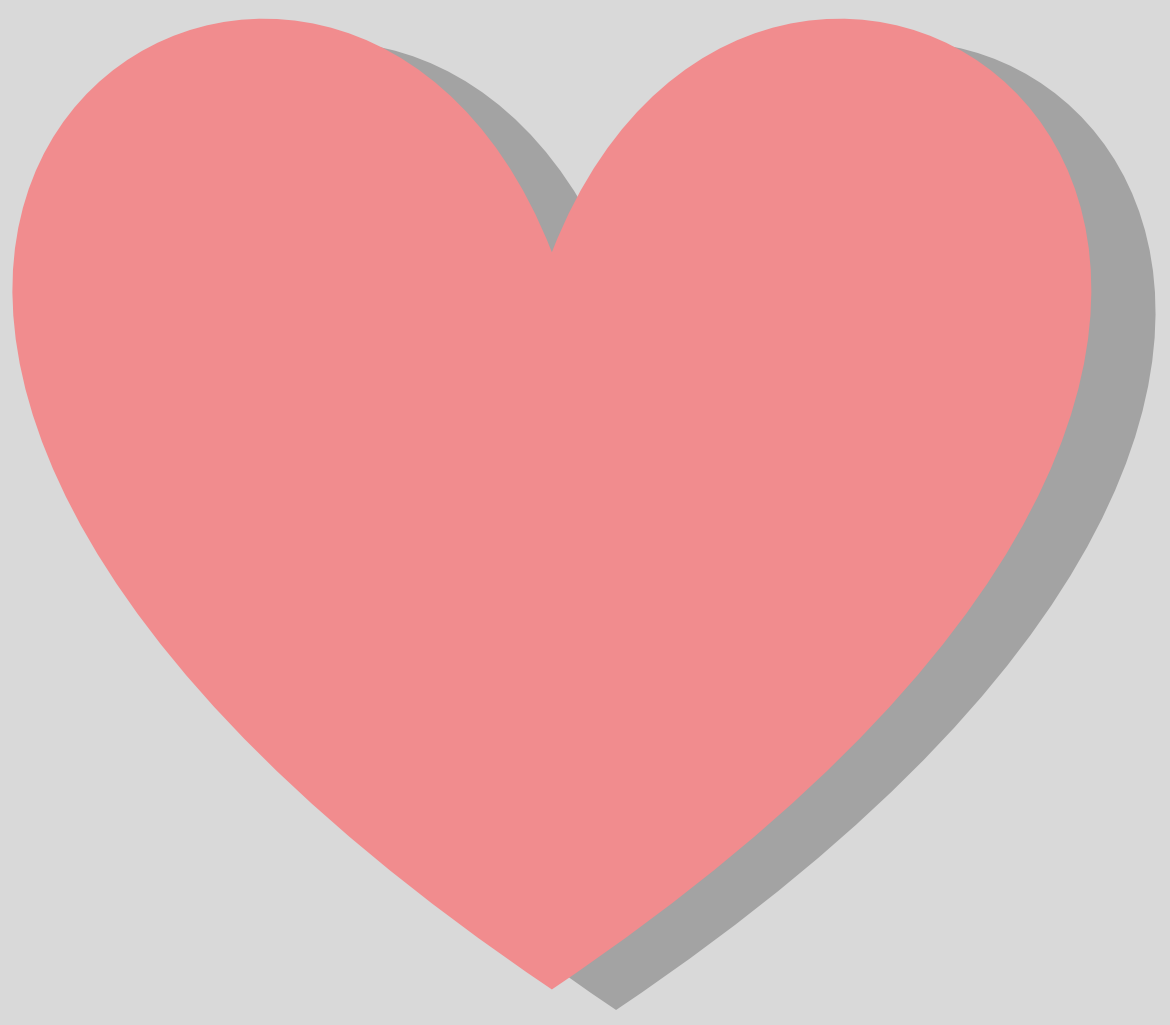

INLEDNING 



\title{
KAPITEL 1 \\ Inledning
}

\begin{abstract}
[A]ccounting information is there to reassure us that everything is 'in order': accounting numbers have become magic words that close conversations about intrinsically doubtful but unquestioned qualities rather than fostering conversations instilling doubt in the user.
\end{abstract}

(Quattrone, 2016, s. 120)

Den här avhandlingen intresserar sig för accounting (hädanefter "redovisning")2 som språk, och dess kraft att beskriva världen och därigenom upprätthålla tilltron till organisationer och samhället. Det rör sig alltså om en bred syn på redovisning som en social (t ex Burchell m.fl., 1980), men framförallt samhällelig, praktik, där redovisningsinformation spelar en central roll för att kommunicera och beskriva världen, och speciellt organisationer. På så sätt bidrar redovisningen till att konstruera bilden av organisationen. Citatet ovan från Paolo Quattrones artikel påminner om att redovisningsinformationen har ett syfte bortom att mäta prestationer och vinst. Den skapar tydlighet och trygghet och har en central roll i

\footnotetext{
2 Med "redovisning" menar jag här och i resten av avhandlingen det begrepp som i engelskans benämns "accounting", som kan anses vara ett något bredare begrepp än redovisning. Accounting kan, beroende på preciserande förled, avse både ekonomistyrning (på engelska används både management accounting och management control), intern- och externredovisning (financial accounting, på engelska och ibland svenska även financial reporting/finansiell rapportering). Ofta förespråkas att göra skillnad på management accounting och financial accounting eftersom de fokuserar på olika aspekter, men författare såsom Nilsson och Stockenstrand (2015) och Taipaleenmäki och Ikäheimo (2013) anser att områdena konvergerar och bygger på samma information. Därmed fångar engelskans "accounting" in flera olika funktioner som använder representationer som produceras av de ekonomiska informationssystemen, och även om jag för läsbarheten valt att översätta detta som "redovisning" så utgår jag alltså från engelskans begreppsinnehåll genom att inkludera såväl den interna ekonomistyrningen som organisationens externa rapportering. Den gemensamma nämnaren för de funktioner jag undersöker empiriskt (ekonomistyrning och rapportering) är att de båda till stor del bygger på redovisningsrepresentationer, vilket är vad som undersöks i relation till visualitet i avhandlingen. En fördel som det svenska begreppet dessutom har, som passar för ämnet i den här avhandlingen (visualitet), är att det bygger på formuleringen redovisning, jämfört med engelskans accounting. Redan i orden förekommer alltså konnotationer till olika idéer om vad redovisningen gör, visualisering respektive räkning, även om begreppen såklart fylls med innehåll av sina användare.
} 
hur vi förhåller oss till både ekonomin och samhället i stort. Exempelvis bygger samhällsplaner och politiska insatser på ekonomiska budgetar, företags existensberättigande kan fastställas utifrån redovisningsbegrepp såsom vinst och avkastning, och länders totala produktion kvantifierar utfört arbete i bruttonationalprodukten. Det går med andra ord knappast att överdriva den centrala roll som redovisningsrepresentationer spelar för människor, organisationer och samhällen.

Det område inom redovisningslitteraturen som denna avhandling, genom det ovan beskrivna intresseområdet, riktar sig mot är representationsproblemet, eller frågan om på vilket sätt redovisningen representerar världen och vad detta får för konsekvenser. Representationer kan skapas, flyttas och aggregeras, och binder därigenom samman delar av samhället; som sociologen Bruno Latour sammanfattar en text om representationer och ekonomin: "Many things can be done with this paper world that cannot be done with the world" (Latour, 1987, s. 226). Representationer av redovisningsinformation bidrar till en "pappersvärld" av sammankopplade beräkningar, som tillsammans konstruerar bilder av företag och samhället och som ger möjlighet att påverka världen (Latour, 1987). Det är därmed intressant att undersöka vad som händer med redovisningens ställning som "the language of business" (Lavoie, 1987; Graham, 2013), spridare av ekonomiska idéer (Suzuki, 2003) och grund för många funktioner i samhället och i organisationer i och med den pågående utvecklingen att nya visuella format växer fram och tar alltmer plats i - och utmanar - det som skulle kunna ses som den "traditionella" redovisningen. Denna utveckling, som i avhandlingen benämns visualitet, har kopplats till en ökning av den visuella logiken i samhället (Warren, 2009). Det har också föreslagits att visualisering förstärker "the already magic persuasive power of accounting numbers", som Quattrone (2016, s. 120) konstaterar i samma text som det inledande citatet. I organisationsforskningen benämns detta ökade intresse ibland "the visual turn of management" (Bell och Davison, 2013; Boxenbaum, Jones och Meyer, 2018).

Trenden går alltså mot att det visuella allt oftare inkluderas i redovisningen, speciellt i årsredovisningar (t ex Graves, Flesher och Jordan, 1996; McKinstry, 1996; Beattie, Dhanani och Jones, 2008; Ditlevsen, 2012b; Hitchings och Taylor, 2013). Beattie m.fl. (2008) beskriver exempelvis hur årsredovisningen sedan 1960-talet blivit mer visuell och mer riktad till externa mottagare, vilket har setts som en sammankoppling av redovisning och marknadsföring (Hopwood, 1996; Beattie, Dhanani och Jones, 2008). För vissa är det dock en självklarhet att bilder är redovisning i likhet med siffror och text:

Contrary to popular, or indeed many an economist's, belief that accounting is all about numbers, matters relevant to accounting (when not passed over altogether in silence) are communicated in three "languages": numbers, words and visual images.

(Davison och Warren, 2009, s. 846) 
Den ökande visualiteten, och speciellt dess roll i att konstruera bilden av organisationen, har lett till ett behov av att integrera ett större visuellt medvetande i studier av organisationer (Bell och Davison, 2013; Boxenbaum, Jones och Meyer, 2018) och redovisning (Davison och Warren, 2009). För även om redovisningen innebär visualisering i någon bemärkelse då den synliggör information så utgår speciellt redovisningsstudier huvudsakligen från numeriska representationer. En viktig fråga blir därmed vad "visualitet" utgör för typ av tillägg till redovisningen, och vad det gör med redovisningens förmåga att konstruera bilden av organisationen, en fråga som också återkommer i organisationsfältet generellt då exempelvis Meyer m.fl. (2013) konstaterar att visuella och verbala format blivit alltmer integrerade med följden att ett format inte kan förstås oberoende av andra representationsformat ${ }^{3}$. På ett liknande sätt noterar Gallhofer och Haslam att konst (som är en form av visualitet) och redovisning ofta ses som separata samhällsfunktioner, men att "they also substantively overlap given their shared character as communicative and representational artefacts" (Gallhofer och Haslam, 1996, s. 23). Samtidigt som det visuella enligt Gallhofer och Haslam alltså kan förstås som något som "överlappar" med redovisningen i bemärkelsen att de har liknande roller som kommunikativa artefakter i samhället har det föreslagits att det finns en viss konflikt mellan den "hårda" ekonomiska epistemologin och det visuellas "mjukare värden" som gör det svårt att kombinera dessa perspektiv (Davison och Warren, 2009).

Med utgångspunkt i detta resonemang intresserar jag mig i den här avhandlingen för visualitet när det möter redovisningen för att konstruera bilden av organisationen ${ }^{4}$. Det teoretiska problemet i avhandlingen är därmed vilka roller det visuella spelar för denna konstruktion - detta återkommer jag senare i kapitlet. Jag undersöker med andra ord gränslandet mellan redovisning och visualitet och på vilka sätt redovisningen konstruerar visuella bilder av organisationer. Vad jag menar med visuella bilder beskriver jag härnäst.

\section{Visuella bilder av organisationer}

Det övergripande temat i avhandlingen är den ökande visualiteten i redovisningssammanhang, det vill säga i områdena redovisning, rapportering och ekonomi-

\footnotetext{
3 Meyer m.fl. (3013) skriver på s. 499 i sin litteraturdiskussion om visualitet i organisations- och managementforskning att, "... verbal text and images have become increasingly integrated, so that neither can be fully understood separately: The message only emerges in and through their interrelation." Jag överför deras slutsatser till att också inkludera numeriska format och därmed appliceras på redovisningen. ${ }^{4}$ Formuleringar i singular, såsom att skriva "bilden" istället för "bilder" trots att det rör sig om olika typer av bilder, och "organisationen" istället för "organisationer" beror på att jag med dessa begrepp avser idén om bilder och organisationer snarare än enskilda bilder eller organisationer. Jag behandlar i artiklarna exempel på visualitet i specifika kommunikationssituationer; dessa är instanser av visualitet, utifrån vilka jag diskuterar visualitet generellt, såsom "årsredovisningen", "organisationen". Min användning av "instansieringar" som empiriska underlag för att dra slutsatser om grupper av visualiseringar diskuterar jag närmare i avsnittet "Vetenskapligt förhållningssätt" i Kapitel 2.
} 
styrning, vilka på engelska kan grupperas under begreppet "accounting", och för vilka redovisningsinformation spelar en central roll. Med bild menar jag här bild i en bred metaforisk bemärkelse, såsom ordet används av exempelvis Gareth Morgan, som ser metaforer som olika "images of organization" (Morgan, 1999). En bild kan alltså vara en idé eller en samling idéer om hur något fungerar, och kan, som i fallet med redovisningen, framställas i form av artefakter; det är främst dessa konkreta framställningar som är av intresse i denna avhandling i och med att den vänder sig till redovisningsområdet, som har en tradition av att undersöka representationer och deras uppkomst och användning.

Med utgångspunkt i antagandet att redovisning är ett språk som liksom andra språk är något man behöver lära sig för att kunna använda så nämner Graham (2013, s. 123) fyra drag i redovisning som språk. För det första bygger det på mätande och har medel för att utföra mätandet (det vill säga pengar). Det har också en finansiell, strukturerande grammatik, samt använder kategorisering för att beskriva världen. Dessa tre aspekter kan tillsammans förstås via metaforen mätbarhet genom att redovisningskategorierna likställs med pengavärdet som tillskrivs dem. Ett exempel på mätbarhetsmetaforen är att organisationers relationer till kunderna ibland uttrycks som en viss mängd pengar (Graham, 2013)5. Redovisningen som språk är med andra ord ett sätt att skapa en kvantifierande, strukturerande bild av organisationen. Med visuell bild menar jag däremot specifikt en artefakt som skapas med visuella medel, det vill säga en bild som bygger på visualitet som språk. När det i litteraturen påpekas att antalet bilder ökar i redovisningen är det i regel visuella bilder som avses (även om det även förekommer studier av språkliga bilder såsom metaforer). Denna ökning beskrivs oftast i termer av att visuella artefakter såsom grafer förekommer i större antal i redovisningen, exempelvis i finansiell rapportering. Det behöver inte innebära att visuella bilder ersätter andra bilder, utan ofta är antagandet att dessa språk i ökande grad förekommer parallellt i redovisningssammanhang (t ex Davison och Warren, 2009).

I de följande avsnitten presenterar jag exempel på visuella bilder som behandlas i avhandlingen. Jag återkommer till former av visualitet i Kapitel 2, men kort beskrivet undersöker jag två varianter av visualitet i denna avhandling. För det första behandlas visualitet som processen att förmedla information med utgångspunkt i antagandet att visualisering kan öka informationstillgängligheten, i exempelvis ekonomistyrning och finansiell rapportering. Avhandlingens exempel är styrningsparadigmet lean, som bygger på så kallad "visual control" (Womack och Jones, 2003), det vill säga styrning med hjälp av visualisering som process, ibland med hjälp av visuella artefakter. För det andra behandlas visualisering som

\footnotetext{
${ }^{5}$ Mer konkret skriver Graham: “After categorizing everything that goes into the story and measuring it in a currency, a simple metaphor is produced by equating each category to its measurement: for instance, the organization's relationship with its customers equals ("is") a certain amount of dollars, broken down into sales, accounts receivable ..." (Graham, 2013, s. 213)
} 
ett format (en artefakt) för att förmedla information, exempelvis grafer och foton. Figur 1 nedan visar exempel på två format som undersöks på djupet utifrån artefaktperspektivet: grafer, vars syfte är att representera numeriska kvantiteter (Tufte, 1990), och diagram, vars syfte är att illustrera konceptuella relationer (Kazmierczak, 2001; Kress och van Leeuwen, 2006; Purchase, 2014). I avhandlingen har jag på olika sätt undersökt visuella artefakter för att förstå deras roller, för att därmed bidra till förståelsen av hur visualitet konstruerar bilden av organisationen i redovisningssammanhang.

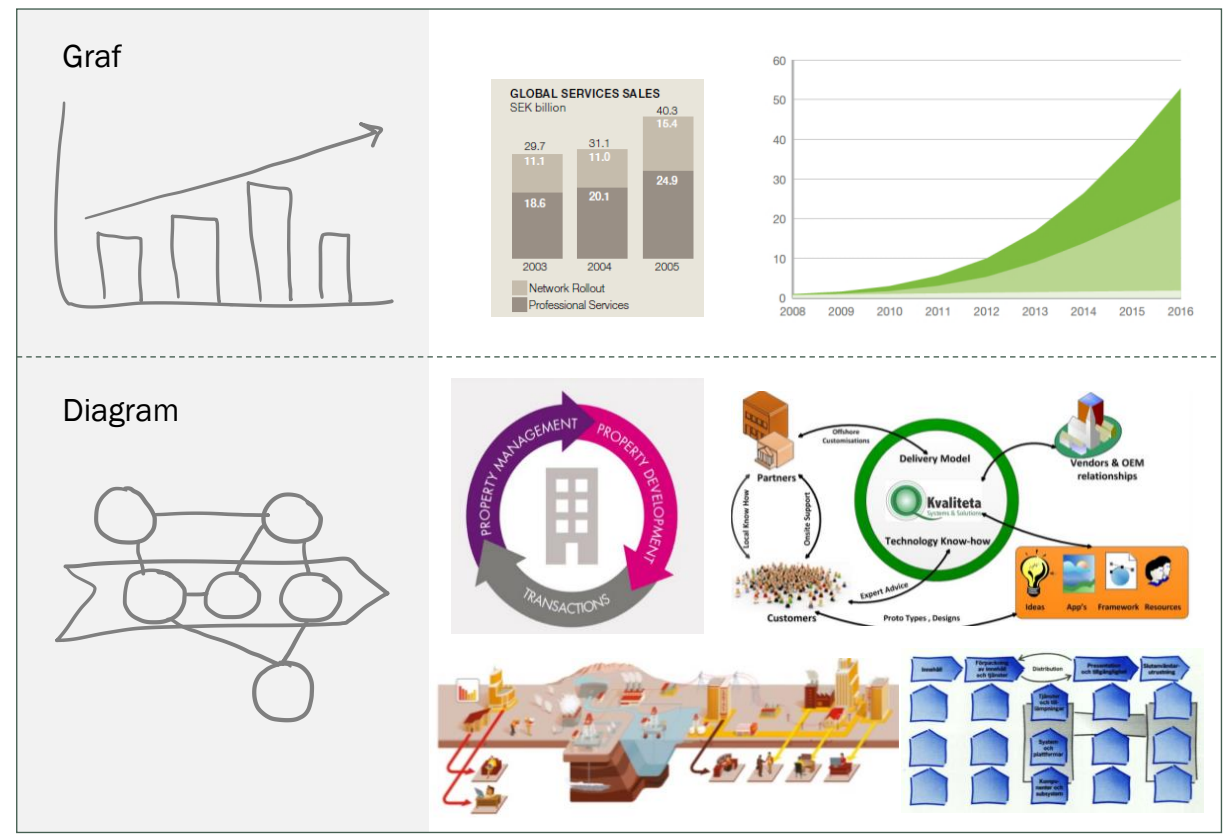

Figur 1. Grafer och diagram med exempel från Artikel I och Artikel II. Källa: se respektive artikel

Ytterligare ett exempel på hur bildspråk kan används som redovisningsinformation visas i Figur 2 på nästa sida. Exemplet är hämtat från min licentiatavhandling (Eriksson, 2017, s. 20), där jag jämför porträtt av Ericssons tidigare VD från två årsredovisningar. Det som är slående med exemplet, och som visar bildspråkets funktion att inte bara representera, utan att även konstruera organisationer (Preston, Wright och Young, 1996), är att dessa två bilder, som till ytan har samma kategorier av innehåll - den avbildade personen (VD), typen av bild (porträtt), utseendet (kostym) och rekvisitan (telefon) - kan vara mycket visuellt olika beroende på hur bilden utformats och konstruerats. Till vänster har vi en VD som i och med sin VD-roll får agera symbol för företaget som helhet, vars allvarliga blick, bruna klädsel och telefonluren vid örat kan tolkas som en upptagen, kompetent chef som tar ledarskapet på allvar. I kontorsmiljön och med 
viktiga dokument framför sig framstår han som en chef med makt och förmåga att påverka verksamheten. Tre år senare har han flyttat ut i det fria, möjligt tack vare företagets mobiltelefoner, och det leende mötet med läsaren ger intryck av öppenhet, tillgänglighet och modernitet. Denna jämförelse av bilder är ett exempel på hur visuell analys kan lyfta fram såväl skillnader som likheter i det visuella språket och därmed dess roller i att konstruera bilder av organisationer.
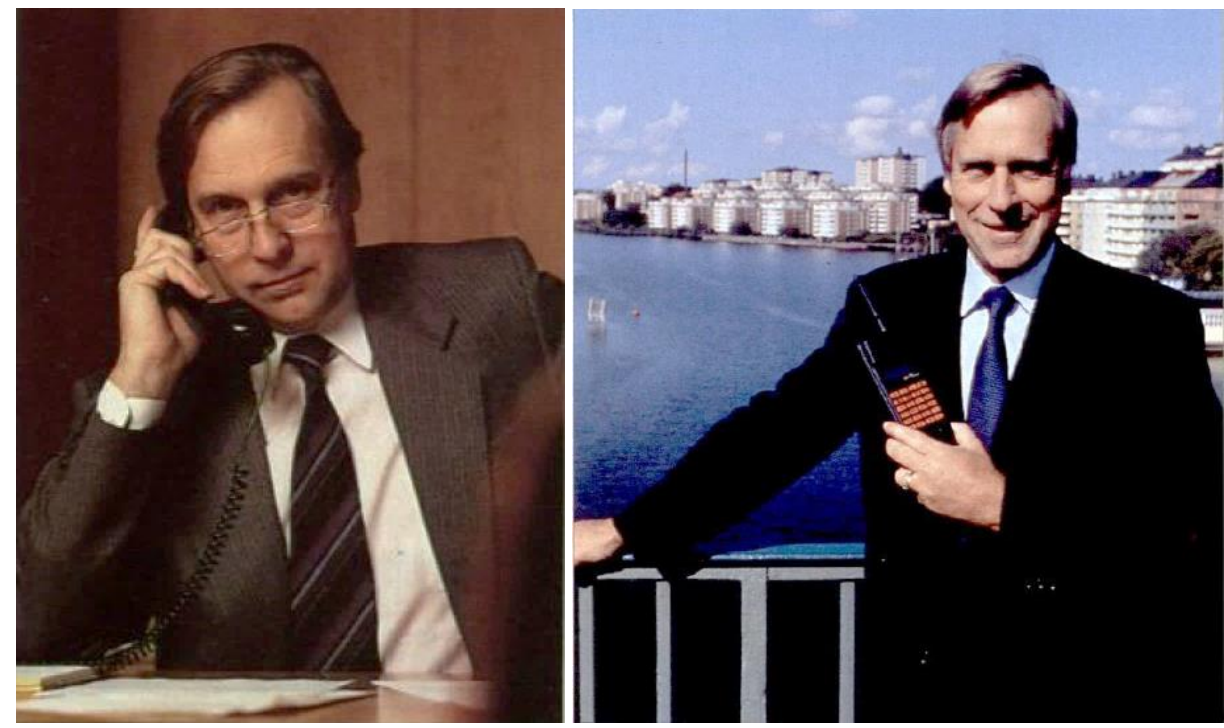

Figur 2. Ericssons VD Svedberg i LM Ericssons årsredovisning 1985 och 1988. Till vänster: 1985 (s. 3), foto Karl-Evert Eklund. Till höger: 1988 (s. 4), foto Leif-Erik Nygårds). Återges från Ericssons arkiv på Centrum för Näringslivshistoria, www.naringslivshistoria.se. Återges med tillstånd från Ericsson, CFN och fotograferna.

\section{Visualitetens teoretiska relevans för redovisningsfältet}

I avhandlingen utgår jag från att analyser likt exemplet med VD-fotona ovan kan öka förståelsen av visualitet, och därigenom också av hur redovisningens representationer blir till och får kraft att påverka världen. Men vad spelar bilder, och speciellt likheter och skillnader såsom de som diskuteras ovan, för roll för vår förståelse av redovisning? Hur vet vi exempelvis att företaget inte bara försöker se tillgängliga och urbana ut med sitt VD-foto som verktyg? Var det verkligen så stor skillnad på företaget vid de två tidpunkterna?

Bakom dessa frågor ligger antagandet att det visuella antingen synliggör eller döljer den verkliga världen, vilket kan vara ett vanligt antagande som dock är värt att problematisera för att nå en mer nyanserad förståelse av visualitet. Med utgångspunkt i en konstruktivistisk syn på redovisning utgår jag från att organisationer genom att beskrivas i redovisningstermer också konstrueras som redovisningsobjekt, eller som Ruth Hines (1988) uttrycker det i titeln på sin artikel 
om denna fråga som att "In Communicating Reality, We Construct Reality". Med detta menas att beskrivningar och kategoriseringar av organisationens personer, miljö och prestationer också skapar bilden av organisationen i redovisningstermer. I linje med detta har det beskrivits hur redovisning kan göra redovisningsobjekt av nästan vad som helst, till exempel anställda (Miller och O'Leary, 1994), fängelser (Andrew, 2011) och miljön (Fourcade, 2011). Denna idé kan också överföras på det visuella, vilket ger upphov till andra grunder för kritik och reflektion om visualitet i redovisningen.

Preston, Wright och Young (1996) föreslår tre steg i att "se" på bilder i finansiell rapportering utifrån Jean Baudrillards text "The precession of simulacra" (Baudrillard, 1981), som beskriver bildens utveckling från medeltiden och framåt. Dessa steg är 1) antagandet att foton ska spegla verkligheten, 2) att framställare av årsredovisningar försöker dölja något i verkligheten, och 3) att foton i årsredovisningar både speglar och skapar verkligheten. Det tredje är det sista "steget" i utvecklingen. Om detta steg skriver Preston m.fl. att bilder inte representerar utan skapar verkligheten, och därför bör analyser och granskningar av dessa inte enbart handlar om att avslöja fel utan snarare om att undersöka och diskutera premisserna för deras representativitet. De skriver:

In this respect, images do not represent, they create reality. Critique is, thus, no longer a question of unmasking false representations of reality or ideology, but rather a question of both revealing and subverting the functioning of the collective apparatuses of subjectivity and reality production, of which mechanical reproduction and, increasingly, the electronic production of images are part.

(Preston, Wright och Young, 1996, s. 134)

Avhandlingen följer detta synsätt i bemärkelsen att jag utgår från att visualitet inte enbart behöver innebära ett sätt att illustrera redovisningsinformation, utan att de kan ha en bredare roll i redovisningssammanhang och kan konstruera nya redovisningsobjekt såväl som visualisera existerande data. En huvudtes inom the visual turn, som även jag utgår från i denna avhandling, är att bilders ökande betydelse som representationsform för med sig nya områden och frågor att utforska. Bell och Davison (2013) föreslår exempelvis att det visuella erbjuder nya möjligheter att uttrycka mening om företag. Davison tillägger i ett bokkapitel om visuell redovisning att "... visual media can carry messages beyond the capacity of accounting statements" (Davison, 2013, s. 58). Davison (2013) noterar i samma text att det visuella innebär fler möjligheter att kommunicera om redovisning och därmed kan stötta organisationers beslutsfattande internt och externt. Hon framhåller vikten av att undersöka det visuellas roll i redovisningen eftersom det visuella blivit vanligt förekommande både i företagssfären och i vardagslivet, och eftersom visuella format har flera fördelar för minne och uppmärksamhet. Det sistnämnda är ett återkommande argument även i kognitiv psykologi (t ex Larkin och Simon, 1987; Tversky, 1997). 
Ett annat centralt argument inom visual turn är att det visuella innebär en ökad möjlighet att konstruera och kommunicera bilden av organisationen. Graves m.fl. (1996) argumenterar exempelvis att bilder i årsredovisningar har en större roll än att fungera som utsmyckningar. Bilder kan likt andra format fungera som påståenden om organisationen (Graves m.fl. använder begreppet "truth claims"), vilket Justesen och Mouritsen (2009) visar även när det gäller användning av bilder internt och externt, och i kopplingen mellan dessa nivåer. Genom att ta visualiteten på allvar som ett sätt att konstruera bilden av organisationen skapas därmed möjligheter att bredda förståelsen av redovisning som samhällelig representationspraktik.

Att det finns ett ökande intresse för visualitetens roll i redovisningen märks också på att det kommit ut flera specialnummer i några av de mest framträdande tidskrifterna inom företagsekonomi och redovisning under de senaste 25 åren: 1996 i Accounting, Organizations and Society (Hopwood, 1996), 2009 i Accounting, Auditing and Accountability Journal (Davison och Warren, 2009), 2012 i Qualitative Research in Organizations and Management: An International Journal (Davison, McLean och Warren, 2012) och 2018 i Organization Studies (Boxenbaum, Jones och Meyer, 2018). Men trots att visualitet alltså tagits upp och beskrivits som icke-trivialt och intressant sedan 1990-talet är det först på senare år som intresset för den visuella dimensionen inom managementforskning fått ökad uppmärksamhet (Davison, McLean och Warren, 2012; Davison, 2013). Bell och Davison (2013) noterar att det dock fortfarande finns behov av att bredda förståelsen av visualitet på ett antal fronter, såsom "blickens konstruktion", visuella metoder och mottagarperspektivet. Så sent som 2018 skrev Boxenbaum m.fl. att intresset ökar men att mycket kvarstår att ta reda på:

\footnotetext{
Overall, there has been a growing interest in ... the role of visuality, and the comparison and consideration of visual and material dimensions of organizations and institutions. Yet, we do not know enough about how novel ideas, and responses to them, are affected by our use of images and artifacts and not only of verbal text.
}

(Boxenbaum, Jones och Meyer, 2018, s. 598)

Det finns med andra ord ett intresse för visualitet och ett behov av fler studier. Samtidigt är bildspråk knappast en nymodighet; bilder har använts för att representera och dokumentera i många tusentals år (Möslein, 2000), och även redovisning som visualiserande beräkningar av tillgångar och skulder har en lång historia på flera tusen år (t ex Macintosh m.fl., 2000). Den tabellbaserade uppställningen av redovisning som började ta form på 1100-talet och framåt kan även den ses som en typ av visualisering av siffror (Tebeaux, 2000; Quattrone, 2009). Det som däremot är nytt är ökande sammanvävningar mellan det visuella och andra format (Meyer m.fl., 2013) i kombination med att det visuella språket i ökande grad beskrivs som ett eget språk för redovisning (Davison och Warren, 2009) och därmed behöver förstås utifrån sin roll i relation till redovisningen. 
Detta motiveras inte minst av Meyer m.fl. (2013), som i sin diskussion av visualiseringsperspektiv i företagsekonomisk forskning konstaterar att fler studier behöver undersöka samspelet mellan det verbala och visuella. De skriver:

\begin{abstract}
... there is a strong need for simultaneously investigating verbal and visual discourse, as well as their mutual influence (...) [0]rganization and management research hasapart from few studies mainly in advertising-rather neglected such interplay of verbal and visual text. A lot of potential, thus, rests in the development of methodological designs that are able to integrate and/or contrast these two modes of communication and discourse.
\end{abstract}

(Meyer m.fl., 2013, s. 522)

Med andra ord står redovisningsfältet nu inför en brytpunkt avseende förståelsen av olika representationsformer för att konstruera bilder av organisationer, och det finns ett behov av kunskap om vilka roller visualiteten kan ha i relation till redovisning. Det teoretiska problemet i avhandlingen är med andra ord hur visualitet i redovisningen kan förstås. I nästa avsnitt presenterar jag avhandlingens syfte och utformning utifrån att det är detta teoretiska problem som utforskas.

\title{
Syfte och utformning
}

Jag föreslår att visualitet kan förstås på fler sätt än som ett alternativt format för att uttrycka något om redovisning, och att det ligger ett teoretiskt och praktiskt intresse i att utforska detta vidare. Detta kopplas till antagandet att visualisering på något sätt hör till, eller utgör en form av redovisning, och att det därmed är viktigt att ge fler perspektiv på detta när redovisning inte kan tolkas som enbart en sifferbaserad praktik. Tills vi har fler svar på vilken roll visualitet har i redovisningen kan själva begreppet "redovisning" sägas vara lite i flux - det är inte uppenbart på vilka sätt vi kan tolka visualitet i förhållande till, eller som ett språk inom ramen för, redovisning. Det är denna fråga jag i avhandlingen avser att kasta ljus på för att möjliggöra en breddad förståelse av premisserna för hur organisationer konstrueras visuellt som redovisningsobjekt. Förhoppningen är att insikter från avhandlingen används för att nyansera förståelsen, och därmed möjligheterna att undersöka, visualitet, samt att de utgör ett bidrag till "the visual turn of management" genom utforskningen av visualitet ur flera perspektiv. Dessa leder till avhandlingens syfte, som formuleras nedan.

Syftet med avhandlingen är att utforska visuella bilder av organisationer för att föreslå sätt att förstå visualitet i redovisningen.

Avhandlingen har också ett praktiskt mål; genom att undersöka perspektiv på visualitet och därigenom öka förståelsen av dess roller vill jag bidra till en ökad visuell läskunnighet hos personer som interagerar med redovisningsinformation. 
Detta är i linje med socialsemiotikerna Kress och van Leeuwen (2006), som nämner visuell läskunnighet som en förutsättning för att kunna navigera i den alltmer visuella världen, speciellt företagssfären.

Kappans kapitel tillsammans med fem vetenskapliga artiklar utgör grunden för att uppfylla syftet. I de följande avsnitten beskriver jag avhandlingens kapitel och sammanfattar artiklarna.

Diskussionerna i avhandlingen får sin teoretiska inramning i form av två perspektiv, det vill säga linser för hur något kan tolkas och förstås, där varje lins kan ge upphov till olika insikter. Perspektiven benämns utvecklingsperspektivet och överlappningsperspektivet. Grunden för dessa utvecklas i Kapitel 2, där jag beskriver utestående forskningsfrågor avseende visualitet i redovisningslitteraturen och diskuterar förklaringsmodeller för överlappning som förekommer i tidigare litteratur. Jag återkommer till dessa perspektiv i Kapitel 5, där avhandlingens resultat och bidrag diskuteras med utgångspunkt i perspektiven. Utifrån utvecklingsperspektivet förstås visualitet genom att fokusera på förändringar av de visuella bildernas roll i finansiell rapportering över tid. Jag undersöker hur visualitet som fenomen har förändrats under 1900-talet eftersom en förståelse av de skeenden som lett till en viss punkt enligt den socialkonstruktivistiska ansats jag använder ökar förståelsen av nuet. Därmed bidrar jag till en förståelse av det visuella nuet med bakgrund av bildanvändningens förändring. Överlappning konceptualiseras i sin tur utifrån förklaringsmodeller för hur visualitet kan relatera till redovisningen, det vill säga hur de överlappar, och överlappningsperspektivet används därmed för att öka förståelsen av språket visualitet och hur det bidrar till att konstruera bilden av organisationen i redovisningssammanhang. Tre modeller för överlappning lyfts i Kapitel 2, separation, konvergens och flerspråkighet. Denna sammanställning föreslås som ett bidrag till förståelsen av visualitet i redovisningen. Av de tre modellerna bygger jag speciellt vidare på den minst utforskade av dem, konvergensmodellen, när jag i Kapitel 5 diskuterar resultaten avseende konvergens av innehåll och aktörer i processen att skapa och använda visuell redovisning.

I Kapitel 3, metodkapitlet, beskriver jag min forskningsansats, och hur jag arbetat med fyra delstudier som ligger till grund för avhandlingens fem artiklar. Jag avslutar kapitlet med en reflektion om hur jag arbetat för att uppnå kvalitet i avhandlingen. När det gäller forskningsmetoderna har använt en tolkande ansats, och har nått fram till slutsatserna genom att frågeställningen om visualitetens roll utforskats i löpande interaktioner mellan helhet och artiklar. Sammanflätning är med andra ord en central ansats i mitt arbetssätt, och jag beskriver därför hur denna utforskningsstrategi bidragit till förståelsen av visualitet i Kapitel 4. I detta kapitel beskrivs även artiklarnas innehåll och deras bidrag till förståelsen av den visuella bilden av organisationen. 
Nedan presenterar jag avhandlingens fem artiklar. Då visualitet är ett interdisciplinärt område som inte bara berör redovisning utan också är en del av en bredare utveckling av meningsskapande och kommunikation i samhället, så har jag valt en bred ansats i valet av empiriska områden. Artiklarna 6 bygger därför på olika empiriska material och vänder sig till (delvis) olika litteraturområden, såsom corporate communication (Artikel II), finansiell rapportering (Artikel IV) och operations management (Artikel V). Varje artikel bidrar dock till förståelsen av visualitet och vilken roll den spelar för att konstruera bilder av organisationer ur ett redovisningsperspektiv eftersom det empiriska materialet utgör exempel på visualitet i bred bemärkelse.

\section{Artikel I: A visual perspective on value creation}

Artikeln klassificerar och jämför affärsmodellsdiagram som använts i företags rapportering. Jag hittar mönster i materialet av 246 affärsmodellsdiagram i form av fyra grundlogiker för värdeskapande: byggstenar, transaktioner, processer och cykler. Artikeln bidrar med exempel på affärsmodellsdiagram som visuella bilder av organisationer, det vill säga konceptuella och visuella självporträtt, och därmed visar jag ett sätt som visualitet konstruerar bilden av den (egna) organisationen i årsredovisningar.

\section{Artikel II: Visual trends in the annual report}

Här beskrivs en longitudinell undersökning av bildanvändning i Ericssons årsredovisningar mellan 1947 och 2016. Jag visar i linje med tidigare forskning att visualiteten är på uppgång då antalet fotografier, diagram och grafer har ökat sedan visuella bilder användes första gången 1947. Dessutom tillför jag ökad förståelse av visualitet i redovisningen över tid genom att visa att bildspråkets karaktär förändrats från att illustrera interna och materiella aspekter till att bygga på vad jag benämner "amaterialitet" - att den visuella bilden "flyttat ut" och "bort" från organisationen, som tidigare illustrerades i form av exempelvis dess anställda, dess byggnader och dess maskiner.

\section{Artikel III: Communicating the business model}

Artikeln beskriver hur begreppet affärsmodell använts som självrepresentation i ett svenskt startup-företag. I artikeln beskriver jag hur affärsmodellsbegreppet kommunicerades olika internt och externt, och tolkades på olika sätt av personer med olika roll i organisationen. Artikeln bidrar genom exemplet affärsmodells-

\footnotetext{
${ }^{6}$ Artikel I-III ingick i min licentiatavhandling och var vid tidpunkten för framläggning i olika skeden av review. Sedan 2017 har speciellt Artikel I och III genomgått omarbetningar; avseende Artikel III baserades de på review-kommentarer och input och reflektion från NFF-konferensen i Bodø 2017 där artikeln presenterades på Business model track. Kappan till licentiatavhandlingen inkluderas inte uttryckligen i avhandlingsmaterialet utöver att den utgör en tidigare version av en del av de tankar som nu presenteras i avhandlingen. När jag vid ett fåtal tillfällen hänvisar till idéer och slutsatser från licentiatavhandlingen så anges detta med källhänvisning till Eriksson 2017.
} 
beskrivningar med att konkretisera kopplingar mellan internt och externt använda bilder, i såväl mentala uppfattningar som i nedtecknade representationer, och visar att olika roller och organisatoriska nivåer kan använda parallella och ickekompatibla beskrivningar av affärsmodellen. Detta är ett exempel på att representationer kan bygga på mångfacetterade tolkningar.

\section{Artikel IV: Get rhythm!}

I artikeln utvecklar jag en visuell metod inspirerad av musikteori för att illustrera och analysera användning av grafer i årsredovisningar. Jag beskriver hur grafer bildar visuella sekvenser i årsredovisningen och därmed konstruerar bilden av organisationen på olika sätt beroende på hur de kombineras med varandra och annan text. En longitudinell analys av rytmer över tid visar att trenden går mot mer integration och mot att fler grafer används, vilket tyder på ökande visualitet i redovisningen. Jag bidrar i artikeln med en ny visuell metod för att illustrera och analysera denna utveckling.

\section{Artikel V: Do employees dream of digital boards?}

I denna artikel utgår jag från perspektivet att visualisering är en process som bidrar till koordinering i ekonomistyrningen. Den studerade kontexten är det visuella styrparadigmet lean. Artikeln undersöker vilka utmaningar som organisationer som arbetar enligt lean kan stöta på när artefakter som används för visuell styrning ska digitaliseras. Bidraget är att beskriva användarnas perspektiv på möjligheter och utmaningar med visuella och digitala styrverktyg samt på användningen av visualisering som styrlogik i praktiken. 


\section{PERSPEKTIV PÅ VISUALITET I REDOVISNINGSSAMMANHANG}





\title{
KAPITEL 2
}

\section{Perspektiv på visualitet $\mathrm{i}$ redovisningssammanhang}

\begin{abstract}
Syftet med detta kapitel är att introducera fenomenet visualitet och beskriva kunskapsläget avseende visualitet i redovisningslitteraturen. Detta gör jag under två huvudrubriker. I avsnittet Tidigare litteratur om visualitet $i$ redovisningen diskuterar jag litteraturen om visualitet generellt, samt tidigare studier som rör redovisningsfältet specifikt. Jag utgår från en analytisk uppdelning i tre områden som visualiseringsstudier kan beskrivas utifrån (funktion, roll och undersökningsnivå), vilken jag använder för att diskutera tidigare bidrag avseende förståelsen av visualitet. Det andra avsnittet, Förklaringsmodeller för visualitetens roll $i$ redovisningen, innehåller en analys av tidigare redovisningslitteratur avseende hur relationen mellan visualitet och redovisning beskrivs, det vill säga överlappning. Syftet med detta avsnitt är att ge exempel på vilka förklaringsmodeller för överlappningar som tidigare lyfts i litteraturen. Som helhet bidrar Kapitel 2 med att presentera central terminologi för att kunna diskutera visualitet i övriga kapitel, samt med en kartläggning av nuvarande kunskapsläge avseende visualitet som fenomen i redovisningen. Med utgångspunkt i detta avslutar jag kapitlet med en diskussion om de utestående frågor i redovisningslitteraturen som jag i avhandlingen bidrar till.
\end{abstract}

\section{Tidigare litteratur om visualitet i redovisning}

Visualitet är ett interdisciplinärt ämne (Ballantyne, 2018) som engagerat forskare inom olika discipliner med olika infallsvinklar, exempelvis i sociologi, ekonomi, 
antropologi, historia och kulturstudier (Meyer m.fl., 2013; Emmison, 2016). Jag knyter an till den interdisciplinära karaktären i det visuella och hämtar kunskap från olika fält för att måla upp visualitet med breda penseldrag. Detta görs genom att ställa upp tre områden utifrån vilka visualitet som ämne kan förstås, nämligen (1) synsätt på visualiseringens funktion, (2) visualitetens roll i studier som antingen metod eller fenomen, och slutligen (3) vilken undersökningsnivå som utgör fokus i studier av fenomenet visualitet. Jag har valt att dela upp dessa områden och diskutera dem separat, men en studie kan naturligtvis beskrivas utifrån en kombination av perspektiv, till exempel en studie av visualisering som fenomen på artefaktnivån ur antingen ett mångtydighetsperspektiv (t ex Davison, 2014) eller ett synliggörandeantagande (t ex Beattie och Jones, 1997). Uppdelningen i dessa kategorier är alltså främst analytisk i syfte att bryta ut beståndsdelarna och därmed förklara hur visualitet kan beskrivas och undersökas ${ }^{7}$. Områdena sammanfattas i Tabell 1 nedan.

Tabell 1. Tre områden (funktioner, roll och undersökningsnivå) för att beskriva visualitet i redovisning

\begin{tabular}{|c|c|c|c|}
\hline & Funktioner & Roll i studier & Undersökningsnivå \\
\hline Beskrivning & $\begin{array}{l}\text { Hur antas det visuella } \\
\text { förhålla sig till det } \\
\text { som representeras? } \\
\text { Vad är det visuellas } \\
\text { syfte som } \\
\text { kommunikativ och } \\
\text { representativ resurs? }\end{array}$ & $\begin{array}{l}\text { Är visuella material } \\
\text { det undersökta } \\
\text { fenomenet eller sättet } \\
\text { att studera ett annat } \\
\text { fenomen? }\end{array}$ & $\begin{array}{l}\text { Studeras bilden som } \\
\text { artefakt med visst } \\
\text { innehåll eller är } \\
\text { fokus på processen } \\
\text { att visualisera? }\end{array}$ \\
\hline Varianter & $\begin{array}{l}\text { Förtydligande } \\
\text { Mångtydighet } \\
\text { Konstruktion }\end{array}$ & $\begin{array}{l}\text { Praktisk metod } \\
\text { Analytisk metod } \\
\text { Fenomen }\end{array}$ & $\begin{array}{l}\text { Kommunikation } \\
\text { Process } \\
\text { Artefakt }\end{array}$ \\
\hline $\begin{array}{l}\text { Exempel på } \\
\text { redovisnings- } \\
\text { studier }\end{array}$ & $\begin{array}{l}\text { Grafer som försök att } \\
\text { vilseleda } \\
\text { Konstruktion av } \\
\text { gemensamma } \\
\text { uppfattningar }\end{array}$ & $\begin{array}{l}\text { Fotoelicitering och } \\
\text { video som metoder } \\
\text { Studier av fenomen i } \\
\text { årsredovisningar, t ex } \\
\text { värderingar, identitet }\end{array}$ & $\begin{array}{l}\text { Undersökning av } \\
\text { visuella artefakter } \\
\text { Bilders roll i } \\
\text { beslutsfattande } \\
\text { Bilder som medel för } \\
\text { kommunikation }\end{array}$ \\
\hline
\end{tabular}

7 Ett alternativt upplägg på indelning av visuella studier förekommer i en litteraturgenomgång av Meyer m.fl. (2013). De delar in studier i fem grupper utifrån deras approach, empiriska fokus och forskningsproblem: arkeologiska studier (fokus på artefakter), praktiska studier (fokus på processen för faktisk användning), strategiska (bilder som kommunikationsstöd), dialogiska (bilder kan användas för att samla in data i t ex intervjuer) och dokumentation (ett sätt för forskare att dokumentera och visa sina resultat). Aspekterna som presenteras i detta kapitel är till skillnad från Meyer m.fl. inte färdiga kluster, utan är snarare en samling synsätt och forskningsupplägg. Däremot hämtar jag inspiration från Meyer m.fl. (och andra) för att beskriva varianter inom de här i avhandlingen föreslagna områdena. 


\section{Visualitetens funktioner}

Det första området avser vilken funktion visualisering antas ha: förtydligande eller mångtydighet. Detta påverkar hur visualisering undersöks och vilken typ av slutsatser som kan dras. En studie med förtydligande (eller synliggörande) som grundantagande om visualisering kan exempelvis undersöka hur väl visuella bilder uppfyller detta mål, och dra slutsatser om hur en visuell bild bör utformas för att på bästa sätt synliggöra information. En studie som utgår från mångtydighet innebär å andra sidan att bilder förstås som mångfacetterade artefakter som spelar olika roller i att kommunicera och beskriva något, och därför är det inte möjligt eller önskvärt att dra slutsatser om de är "rätt" eller "fel", utan snarare hur de fungerar som resurser, och varför.

Antagandet att visualiseringen har en synliggörande och förtydligande funktion förekommer i litteratur om informationsvisualisering och -design, som intresserat sig för hur data kan representeras effektivt (t ex Tufte, 1990; Card, Mackinlay och Shneiderman, 1999; Eppler, 2006; Agrawala, Li och Berthouzoz, 2011; Lima, 2011). I detta fält diskuteras ofta olika tekniker för framställning och presentation av data med målet att synliggöra mönster och göra datan lätt att förstå, något som kan ses som en konstform i sig (se t ex Shneiderman och Lima, 2014). Edward Tufte (1990), som är en välkänd person inom informationsvisualisering, lånar termen “kognitiv konst” för att beskriva goda visualiseringar som följer principer såsom enkelhet och tydlighet, medan han använder begreppet "chartjunk", det vill säga grafer med onödiga utsmyckningar som inte tillför något till budskapet, för det motsatta. Ett motexempel är Dragga och Voss (2001), som föreslår att inkludera illustrativa ritningar av till exempel gråtande barn även i grafer för att lyfta fram mänskliga aspekter som annars ofta döljs bakom standardiserade staplar och siffror. Deras förslag möter dock kritik av Doumont (2002), som inte anser det lämpligt att lägga till sådana utsmyckningar. Det finns med andra ord olika syn på hur visualiseringen ska gå till, även om målet effektiv visualisering av data ofta är gemensamt.

En utgångspunkt för antagandet att visualisering synliggör är att det förbättrar kommunikationen om man skapar representationer som följer blickens logik, det vill säga att vi upplever och förstår världen genom våra ögon. Larkin och Simon (1987) har skrivit en välkänd artikel som föreslår att "diagram (ibland) säger mer än 10,000 ord" eftersom ett diagram (i deras fall mekaniska ritningar) kan illustrera matematiska problem bättre än siffror då siffror inte matchar upplevelsen av den avbilade mekaniska konstruktionen på samma direkta sätt som diagrammet. Att ställa upp information visuellt föreslår Larkin och Simon leder till "cognitive enhancement" och därmed förbättrad problemlösning. Detta kan kopplas till att det som ibland kallas "seendets logik" är välutbredd som ett sätt att uppfatta och konstruera mening utifrån antagandet att det vi ser med våra ögon är verkligt. Detta kan kopplas till ett antagande att bilder är transparenta, som gör att bilders epistemologiska status som avbildare av världen sällan 
ifrågasätts (Brown, 2010). Bell och Davison (2013, s. 175) beskriver detta i termer av en "transparensmyt" - att bilder antas visa något sant och existerande. Idén om "blicken" behöver dock inte förstås som inhämtandet av rena sinnesintryck utan kan bygga på ett inlärt sätt att uppfatta bilder utifrån olika kulturella koder och kunskaper (Berger, 1972).

I studier som utgår från synliggörandeantagandet - och transparensidealet - läggs ofta fokus på hur information presenteras visuellt baserat på olika data, och hur man säkerställer att det finns en tydlig koppling mellan data och representation. Stämmer de inte överens så kan det betyda att det är något fel på representationen, och detta fel tillskrivs ofta skaparen av den. Exempelvis är en vanlig utgångspunkt i litteraturen om finansiell rapportering att "ickerepresentativa" bilder utgör "impression management (Beattie, Dhanani och Jones, 2008; Brennan, Guillamon-Saorin och Pierce, 2009; Falschlunger m.fl., 2015), det vill säga försök att påverka läsarens förståelse genom grafisk formgivning och språkbruk. Utformning av grafer har varit ett återkommande ämne inom detta tema i rapporteringslitteraturen (t ex Steinbart, 1989; Beattie och Jones, 1997; Courtis, 1997; Laidroo och Tamme, 2016). Courtis (1997) visade exempelvis att av grafer använde skeva axlar för att ge intryck av bättre resultat än vad som rapporterades i siffrorna i Hongkongbaserade företag, och andra har tillämpat olika beräkningsmetoder för att mäta hur mycket grafer felrepresenterar underliggande kvantitativa data och i vilken utsträckning företag väljer att visualisera enbart positiva resultat i grafer, så kallad selectivity (t ex Steinbart, 1989; Mather, Ramsay och Serrey, 1996; Laidroo och Tamme, 2016). Brennan m.fl. (2009) har skapat ett ramverk för olika typer av impression management, i vilket det visuella behandlas som en presentationsform som påverkar intrycket genom att exempelvis förstärka andra budskap. Här spelar det visuella alltså en roll främst som stöttande format ${ }^{8}$. Detta tyder på en snäv tolkning av visualitet, och det finns potential att bidra till att bredda förståelsen av visualitet genom att ge exempel på hur visualitet konstruerar på fler sätt än enbart som förstärkning av siffrorna.

Det är främst empiristiskt drivna studier som utgår från transparensantagandet (Bell och Davison, 2013). Parallellt med denna litteratur har också en mer tolkande strömning fokuserat på det visuellas mångfacetterade natur när det gäller att konstruera bilden av organisationens prestationer (t ex Graves, Flesher

\footnotetext{
8 Denna litteratur studerar inte enbart bilder, vilket framgår exempelvis i ramverket för typer av impression management av Brennan m.fl. (2009), där visualisering i bemärkelsen att framställa redovisningsdata i visuella termer ses som ett av många sätt att medvetet påverka läsarens intryck. Ett exempel på ickevisuell påverkan är användning av icke-normerade resultatmått (Deegan och Unerman, 2005) vilket försvårar jämförbarhet för investerare (Scheja, 2009). Jämförbarhet är att betrakta som central norm och funktion inom både ekonomistyrning och finansiell rapportering. Genom att både undersöka rapporterad information och genomföra intervjuer med framställare fann dock Scheja att det som kunde tolkas som rapportering av vilseledande information inte alltid berodde på medvetna försök att vilseleda utan att det bara blev så, delvis på grund av okunskap hos framställarna.
} 
och Jordan, 1996; Preston, Wright och Young, 1996; Davison, 2008; Campbell, McPhail och Slack, 2009; Justesen och Mouritsen, 2009). Sett ur detta perspektiv kan visualiseringar ha många parallella betydelser, och är användbara på grund av (inte trots) denna mångtydighet (Rose, 2001). Ett exempel på en studie som bygger på mångtydighetsantagandet är Davisons (2014) diskussion av det visuellas roll i rapportering av intellektuellt kapital. Hon hänvisar till att bilder, filmer och arkitektur (det vill säga andra representationsformer än den kvantifierande klassificeringen) påverkar uppfattningar om redovisning och redovisare. En av hennes huvudpoänger är att bilders koppling till känslor och möjligheten till samtidighet i representerande och konstruerande ger bilder kraft att påverka samhällsdiskursen, och att det därmed är av intresse även för redovisningslitteraturen att förstå hur de fungerar. Detta ligger till grund för hennes förslag på teori om visuell redovisningsretorik; Davison visar sedan $\mathrm{i}$ tillämpningen av sin teori hur företagsbilder främjar förmedlande av flera samtidiga budskap och att man genom att undersöka visuell utformning kan förstå hur mening skapas i finansiell rapportering.

Jämfört med synsättet att bilder innebär transparens och ska utvärderas utifrån hur väl de representerar verkligheten så kan antagandet om bilders konstruerande funktion leda till kritik mot bilder som enligt den representativa synen vore godtagbara som transparenta avbildningar av en förväntad verklighet. Ett exempel på det är undersökningar av årsredovisningars framställningar av män och kvinnor (Anderson och Imperia, 1992; Duff, 2011; Staffansson Pauli, 2016). Anderson och Imperia (1992) undersökte exempelvis hur kvinnor och män avbildades i flygbolags årsredovisningar, och fann att kvinnor ofta presenterades som passiva och leende medan män var aktiva och seriösa, vilket de menar reproducerade och förstärkte stereotyper om män och kvinnor genom bildvalen.

Sammanfattningsvis beskriver detta område, visualitetens funktioner, olika sätt att tolka hur bilder förhåller sig till redovisningen och på vilket sätt de uttrycker redovisning - det vill säga olika antaganden om det visuellas representativa och kommunikativa funktioner. En parallell kan dras till den bredare debatten om redovisningen som representerande eller konstruerande praktik, det vill säga huruvida redovisningens syfte är att representera verkligheten så korrekt som möjligt eller om det handlar om att konstruera organisationer och samhällen genom att beskriva dem i redovisningstermer9. Sundström (2015), som undersökte användning av redovisning på en svensk teater, fann till exempel att redovisningsrepresentationer kunde innehålla multipla betydelser, men han påpekar samtidigt att redovisningen inte skulle acceptera mångtydighet framför korrekthet eftersom detta går emot redovisningens ontologi, vilket kan tolkas som

\footnotetext{
9 Det kan noteras att det poängterats att antagandet om att redovisningsrapporter avbildar en objektiv verklighet fortfarande är vanligt förekommande i viss redovisningslitteratur (Amernic och Craig, 2009) men att detta ibland beskrivs som ofördelaktigt (rent av "misguided") av den andra sidan (t ex Suzuki, 2003).
} 
att det finns en redovisningsontologi som bygger på ett ideal av förtydligande. På dessa grunder skulle andra former som möjliggör mångtydighet kunna avfärdas som icke redovisningsmässiga ${ }^{10}$.

Jag föreslår att dessa idéer i stor utsträckning går att spåra även i synen på det visuellas roll, det vill säga om det visuella möjliggör bättre beslutsfattande och förståelse av redovisningsinformation genom att synliggöra redovisningsdata och därmed kan granskas utifrån transparensidealet - eller om det visuella ger möjligheter att uttrycka nya områden av organisationen på nya sätt - och därmed kan förstås och utvärderas utifrån sin mångtydighet. Beroende på vilket synsätt som utgör utgångspunkten för en studie uppstår därför olika grunder för tolkning och läsning av redovisningsinformation. Detta gäller för redovisningen i allmänhet såväl som för det visuella, vilket därmed också påverkar vilka slutsatser som kan dras om redovisningen och visualiteten i en studie.

\section{Visualitetens roller i studier}

Det andra området innebär en beskrivning av det visuellas roll i en studie, det vill säga om man med "det visuella" avser en visuell metod för att undersöka ett annat fenomen, eller om det visuella är det fenomen man är intresserad av, det vill säga undersökningsobjektet. Detta kan kopplas till Lukka och Vinnari (2014, 2016), som noterar att det finns utrymme att vara tydligare avseende vilka teorier som utgör perspektiv och undersökningsmetoder, och vilka som är den gemensamma kunskapsbasen i ett fält. De delar in teori i domänteori (kunskaper om ett ämne som växer fram över tid och konstrueras dialogiskt i fältet) respektive metodteori (den konceptuella linsen som ett fenomen undersöks utifrån). De föreslår att denna uppdelning kan tydliggöra om ett bidrag riktar sig till existerande domänkunskaper eller till metodteorier; utan denna uppdelning finns risken otydlighet uppstår avseende hur en studies mål, teori och bidrag ska tolkas och utvärderas. Överfört på visualisering i redovisningen gör jag antagandet att det inte är oväsentligt att man tydliggör typen av bidrag från en studie för att förstå hur visualitet förhåller sig till domänkunskaper om redovisning.

Flera sammanställningar av, och diskussioner om, managementlitteratur inom the visual turn (t ex Bell och Davison, 2013; Meyer m.fl., 2013) inkluderar visualisering som fenomen och visualisering som metod på samma konceptuella nivå, och gör alltså inte uttryckligen skillnad på om visualisering utgör studiers domänbidrag eller använda metod (eller båda). Om dessa likställs finns dock en

\footnotetext{
10 Cooper och Sherer (1984), som närmar sig ämnet ur ett bredare sociopolitiskt perspektiv, lyfter frågan varför kommunicerbarhet överhuvudtaget ses som ett mål för (den externa) redovisningen, en fråga som gäller oavsett om en objektiv verklighet antas synliggöras eller inte. Deras svar är att sådana antaganden förutsätter att det är viktigt att producera kommunikativa dokument och att det därför är eftersträvansvärt att dokument produceras, vilket förutsätter att de läses och har en roll i beslutsfattande. Detta antagande kan i någon mån ses som en måttstock för redovisning, det vill säga att redovisningsinformation delvis bedöms utifrån hur användbar den är för användare som ska bilda sig en uppfattning om organisationer eller fatta beslut.
} 
risk att det blir svårare att jämföra studierna, speciellt avseende förståelsen av en visuell studies teoretiska bidrag till redovisningsfältet.

I detta avsnitt utgår jag från ovanstående resonemang och föreslår att visualisering kan ha (minst) tre olika roller i en studie: som undersökt fenomen (målet är att undersöka och förstå en visuell bild i sig), som analytisk metod (att använda visualisering som metodteori i syfte att undersöka andra fenomen) samt som praktisk metod (visualisering är en metod för att samla in och dokumentera data, det vill säga ett hjälpmedel för forskaren). Jag beskriver var och en av dessa tre roller nedan med löpande kopplingar till tidigare litteratur generellt och till redovisningsfältet specifikt.

I och med att bilder kan anses innebära ett eget sätt att se världen (Larkin och Simon, 1987) har exempelvis Bell och Davison (2013) föreslagit att visuella metoder kan användas för att förstå organisationer på nya sätt utifrån den visuella epistemologin. Att använda visualisering som ett hjälpmedel för forskningen, det vill säga som praktisk metod, ligger i linje med denna syn på det visuellas möjligheter. Ett exempel på en praktisk metod är "fotoelicitering"11 (på engelska photo elicitation) som används för att undersöka organisationer och anställdas upplevelser; intervjupersoner kan exempelvis få i uppgift att skapa eller se på bilder och diskutera dem (Tracy och Redden, 2016), exempelvis för att diskutera och utvärdera arbetsmiljön (Ray och Smith, 2012). Även videobaserade forskningsstrategier har föreslagits som visuell metod (Emmison, 2016). Ett exempel är att använda film som dokumentering av råmaterial för forskningen, som i Albinssons (2016) studie av barns matematiska tänkande, där förskolebarns legolek filmades för att sedan transkriberas och analyseras. Video kan också användas likt fotoelicitering som intervjustöd genom att intervjupersoner får titta på inspelad film och beskriva sina erfarenheter i efterhand för att därigenom fånga in aspekter de kanske inte var medvetna om vid själva händelsen (Toraldo, Islam och Mangia, 2018). Ett annat exempel är att använda visualitet som en designmetod, där något visuellt skapas inom ramen för forskningsarbetet. Ehrnberger (2017)12 visualiserade design av produkter

\footnotetext{
11 Ett exempel från ett (misslyckat men uppdaterat) försök att använda fotoelicitering ger en indikation på dess möjligheter och utmaningar. Ray och Smith beskriver sina erfarenheter på följande sätt: "When the photos were shown to several workers and managers, they laughed or looked perplexed; they were not able to provide any commentary on how the photographs were connected to priorities. The researcher rephrased the question several times but soon realized that the problem was the selected photos [...] During the interviews, something unanticipated happened. The research participants suggested to the researcher organizational elements that should be photographed [...] the hybrid photo production of organizational members guiding which photos the researcher needed to take was critical to gain insight into the research question." (Ray och Smith, 2012, s. 308-309). Exemplet visar hur målet att visualisera kan stötta gemensam förståelse och kommunikation både i själva framställningen av det visuella tillsammans med intervjupersonerna, och samtidigt att det blir viktigt med valet av bilder, något som kan vara svårt för intervjuaren som inte har samma kännedom om organisationen som dess medlemmar.

12 Ehrnberger undersöker exempelvis innebörden av produkter riktade till kvinnor respektive män genom att "byta plats" på designnormerna för en skruvdragare och en köksmixer. Skruvdragaren fick runda former och en nätt design medan köksmixern fick en funktionell design, stark motor och större storlek; detta platsbyte tvingade fram reflektion om vilka normer som skulle överföras vid platsbytet, och som styr design.
} 
vilka användes för normkritisk reflektion om genus i en doktorsavhandling inom designområdet. I dessa exempel är det visuella ett verktyg för att samla in och dokumentera ett empiriskt område, och här har visuella artefakter alltså rollen som praktisk metod i en studie.

Denna praktiska användning av visualisering kan jämföras med visualisering som analytisk metod. Jag använder begreppet analytisk metod för att beskriva studier där visuella artefakter undersöks i syfte att svara på en fråga som inte rör visualiseringen som sådan. Det kan krävas visuella metoder för att göra detta, men själva bilderna utgör i första hand en källa till kunskap om ett annat fenomen. Ett exempel på en sådan studie genomfördes av Overud (2019) som studerade historiska identiteter ur perspektivet kolonial retorik genom analys fotografier från början av 1900-talet. Årsredovisningar lämpar sig speciellt bra för att studera olika fenomen genom att använda visuell analys som metod. Davison och Warren (2009) skriver att bilder i årsredovisningar “... not only project images outwards towards society, but may also, often unconsciously, reflect society” (s. 850). Baserat på detta kan bilder vara en källa till information om svåruttryckliga eller mångtydiga betydelser, där visuella metoder ger möjlighet att fånga in och undersöka samhälleliga fenomen. Detta skiljer sig från de praktiska metoderna eftersom dessa till skillnad från analytiska metoder går ut på att använda det visuella som ett sätt att samla in och dokumentera information, medan analytiska visuella metoder i större utsträckning undersöker existerande visuella material som uttryck för samhällsfenomen.

Det finns även en skillnad mellan analytiska metoder och undersökning av visualitet som själva fenomenet, även om gränsdragningen mellan metod och fenomen är något flytande: det som uttrycks med visuella bilder är ju också ett uttryck för visualitet även om bilderna inte analyseras ur det perspektivet. Studier av visualitet som fenomen kan i sin tur också bygga på visuella metoder, såsom när Hrasky (2012) använde bildanalys för att visa att företags visuella retorik kan kopplas till omfattningen av hållbarhetsarbetet i praktiken (ju fler faktiska hållbarhetsaktiviteter som genomfördes, desto färre symboliska bilder användes i hållbarhetsrapporteringen). Detta tolkade Hrasky som greenwashing eftersom bilder ersatte handlingar och vice versa - i detta fall handlade det alltså inte enbart om vad bilderna visade utan om bilders retoriska funktion att ersätta handlingar. En analys som uttalar sig om ett annat fenomen med visuell metodteori antar jag därför också innebära en möjlighet att öka kunskapen om visualiteten som uttryckssätt.

När de gäller visualitet som fenomen är studier av årsredovisningars uttryck för genusstereotyper, såsom det som beskrevs i det föregående avsnittet om visualisering som mångtydighet, ett exempel från redovisningslitteraturen. Syftet med dessa studier (t ex Anderson och Imperia, 1992; Duff, 2011) kan vara att undersöka det visuellas roll i att reproducera vissa (stereotypa) budskap, och slutsatserna har ibland antagit ett normkritiskt förhållningssätt för att påpeka att 
det undersökta bildspråket förstärker uppfattningar och fördomar. Ett annat område som undersökts i tidigare forskning är identitetsskapande genom årsredovisningens bildspråk (Ditlevsen, 2012a; Kamla och Roberts, 2013). Breitbarth m.fl. (2010) identifierade exempelvis visuella strategier för att kommunicera organisationers förhållningssätt till CSR, däribland "the accountant approach" (att inte använda bildspråk utan "redovisningsspråk" såsom text och siffror för att visa allvaret i situationen), "the people approach" (att visa foton på glada människor som vinner på CSR-arbetet) och "the dream world approach" (att använda generiska visuella symboler, exempelvis flygfoton på gröna skogar). Genom dessa exempel visar de hur visualitet används som språk för att konstruera bilden av CSR, samt vilka visuella bilder som konstrueras, med följden att förståelsen av visualiteten som språk avseende CSR-arbete ökar.

Bell och Davison (2013) ser en stor potential i teoretiskt grundade studier som utgår från visualitet som ett meningsskapande system på samma nivå som andra språk. Den centrala uppdelningen i deras diskussion är mellan empiriska (mer materialfokuserade) och mer teoretiskt drivna studier, där empiriska studier ofta använder antingen innehållsanalys med fokus på visuella fenomen eller fotoelicitering. De ser dock den största potentialen i mer teoretiskt grundade studier av visualitet, eftersom dessa "... are characterized by their assertion of the importance of the visual as equivalent to linguistic structures of meaning in the constitution of organizational life" (Bell och Davison, 2013, s. 180). Det finns alltså enligt Bell och Davison utrymme för att använda teoretiska perspektiv på visualitet för att öka förståelsen av visualiteten som system för att konstruera mening i organisationer.

\section{Visualitetens undersökningsnivåer}

Det tredje och sista området handlar om undersökningsnivån. Här föreslår jag att göra skillnad på om visualisering ses som en artefakt eller som en process. Detta följer två av de kategorier som lyfts av Meyer m.fl. (2013) i deras litteraturgenomgång, nämligen arkeologiska approacher som undersöker artefakter och processtudier som undersöker artefakters användning i praktiken. Enligt Meyer m.fl. förstås visuella artefakter på ett liknande sätt i båda approacherna, även om de utgår från olika typer av empiri, antingen artefakterna som sådana eller användarnas interaktion med dem. Visuella artefakter förstås dock alltså på ett liknande sätt i båda fallen, nämligen som "... a manifestation of culture whose meaning, relevance, and use are socially constructed by a particular community or society" (Meyer m.fl., 2013, s. 504). Det handlar med andra ord om att undersöka det visuellas roll som meningsbärare i sociala sammanhang, och, när det gäller det processperspektivet, också om ett mål att förstå vad visuella artefakter "faktiskt gör" (Meyer m.fl., 2013).

I studier av det undersökta fenomenet visualitet är fokus ofta på visualisering som antingen praktik eller artefakt; en tredje variant som hamnar i 
gränslandet mellan artefakt och praktik är att istället studera kommunikationsprocessen. Här är fokus på produktionskedjan från skapande till distribution av en artefakt, inklusive vad som möjliggör framställning ( $t$ ex tekniska förutsättningar) och utformning av budskapet utifrån målgruppens behov för att uppnå hög effektivitet på kommunikationen. Detta perspektiv utgår från att det är undersökningen av själva kommunikationsprocessen och dess möjligheter och utmaningar som kan ge svar på frågor om bilders kommunikativa roller. En teori som ofta återkommer i dessa studier är Shannon och Weavers (1949/1964) kommunikationsmodell, som lyfter fram att budskap på vägen från framställning till mottagare rör sig igenom brus och utsätts för tolkning när det väl når mottagaren, vilket kan påverka om budskapet når fram eller inte. I denna avhandling kommer jag inte att fokusera på detta perspektiv.

Visualisering som process fokuserar på processen att skapa, och framförallt använda, en visuell artefakt mer än artefakten som slutprodukt. och utgår från antagandet att visuella representationer gör det möjligt att illustrera och dela idéer på för att exempelvis kunna kommunicera i grupp (Tversky, 1997; Sibbet, 2008) eller arbeta fram strategier (Eppler och Platts, 2009). Idén om ett växelspel mellan visualisering och dialog i strategiarbetet förekommer också i den ekonomistyrningslitteratur som föreslår att koppla samman strategi och styrning i strategikartor (Petri och Olve, 2014; Falk m.fl., 2016). Strategikartan är ett exempel på visualitet och redovisning, eftersom kartan, åtminstone till en början, var tänkt som ett komplement till balanserat styrkort. Balanserat styrkort, skapat av Kaplan och Norton, är ett sifferbaserat styrverktyg som bygger på mätning av flera perspektiv för att ge en helhetsbild av verksamheten för att förbättra beslutsfattandet (Kaplan och Norton, 1992, 1996/2007). Med tiden utvecklades idén att detta verktyg skulle vara grundat i strategin (Falk m.fl., 2016), vilket Kaplan och Norton (2000) omsatte i idén om en strategikarta som visualiserar strategin med kopplingar till viktiga nyckeltal. Genom åren har strategikartor som styrverktyg diskuterats och undersökts i ekonomistyrningslitteraturen (t ex Kaplan och Norton, 2004; Lowe, Carmona-Moreno och Reckers, 2011; Cheng och Humphreys, 2012; Islam, 2018). Ledin och Machin (2016) visar att strategikartan under samma period använts av många organisationer för att i externa kanaler illustrera sina strategier på sätt som i minskande utsträckning följer det ursprungliga konceptet. Detta kan tolkas som att strategikartan inte enbart används som struktur för att synliggöra kopplingar mellan mätetal och strategin, utan också är en idé för att visualisera organisationers strategier mer generellt.

Ett exempel på en strategikarta förekommer i Falk m.fl. (2016), som beskriver Parks and Resorts arbete med att designa en strategikarta och ett balanserat styrkort. Exemplet, som jag beskriver i Exempelruta 1 på nästa uppslag, bidrar med en pusselbit till förståelsen av det visuella i redovisningssammanhang genom att visa hur artefakter konstrueras både med utgångspunkt i strategi och redovisning, samt att artefaktens möte med personer och aktiviteter i organisationen påverkar 
dess utformning. Den visuella strategikartan användes, som exemplet visar, tillsammans med en strategiberättelse som förklarade kartan i ord, vilket är speciellt intressant med tanke på frågan om överlappningar mellan det visuella och redovisningen då det kan tolkas som en länkning snarare än en direkt överlappning. Ett relaterat exempel på visualisering och kommunikation av balanserade styrkort förekommer i en studie av Qu och Cooper (2011), som undersökte artefakters roll när en kanadensisk konsultfirma skulle ta fram ett balanserat styrkort till en kund, som dock vid leveransen av styrkortet inte upplevde att det var användbart då det inte var tillräckligt detaljerat. Detta talar för att det finns en förväntan hos praktiker att ett balanserat styrkort inte bara ska vara för syns skull, utan att det ska tjäna ett syfte i organisationen. Det behöver finnas kopplingar mellan mätningar och illustrationen av dem, vilket inte var fallet i Qu och Coopers studie, och som till slut ledde till att konsulterna fick återkomma med nya visualiseringar för att förklara styrkortet (alltså i första hand bättre förklaringar snarare än bättre mätetal).

Vidare har litteraturen om finansiell rapportering undersökt förekomster av artefakter, och hur de används i redovisningen. Bland dessa finns t ex Jane Davison (2008, 2010, 2014), som undersökt retoriska uttryck i årsredovisningsbilder och som visar att de kan användas för att uttrycka organisationens identitet och andra budskap, samt Guthey och Jackson (2005) som undersökte VD-foton i termer av en "autenticitetsparadox" (ju fler som har "unika" bilder för att framställa sin VD, desto mer lika blir företagen och desto mindre autentiska upplevs bildspråk och organisation). Det har även gjorts longitudinella studier av utvecklingen av visualitet över tid (t ex McKinstry, 1996; Beattie, Dhanani och Jones, 2008; Ditlevsen, 2012b) som visar att det visuella tar en allt större plats som format för att presentera organisationens resultat. McKinstry (1996) undersökte ett brittiskt företags årsredovisningar från 1930-tal till 1980-tal och konstaterade att antalet bilder blivit fler, och noterade bland annat även att svartvita bilder användes vid sämre resultat för att signalera en sober atmosfär och därmed att företaget tog situationen på allvar, vilket är en förklaring av visualitet som språk och fenomen. Ditlevsens (2012b) longitudinella studie av ett danskt företags årsredovisningar visade på en utveckling mot mer omfattande narrativt innehåll, och en mer visuell årsredovisning mätt i antalet bilder indelade i olika typer såsom symboler och ikoner. McKinstrys och Ditlevsens studier är dock något av undantag i sammanhanget, eftersom det generellt lagts mindre fokus på att karaktärisera hur bildspråket i årsredovisningar förändrats än på att beskriva att årsredovisningen som dokument blivit mer visuell. Det finns med andra ord ett behov av att undersöka hur årsredovisningens visuella språk förändrats avseende artefakternas funktion, för att därmed förstå de visuella artefakternas (förändrade) roll i redovisningen.

Slutligen vill jag nämna att område som länge intresserat sig för visualitet, nämligen litteraturen om företags beslutsfattande, där redovisningsinformation 


\section{Exempelruta 1: Parks och Resorts strategikarta}

I denna ruta beskrivs Parks \& Resorts arbete med att skapa en strategikarta, som ett exempel på praktisk användning av en visuell artefakt $\mathrm{i}$ ekonomistyrningen. Parks and Resorts (P\&R) driver flera nöjesparker i Sverige, däribland Gröna Lund och Kolmården, och tog runt år 2010 fram och använde en lekfullt illustrerad strategikarta (verkamheten och styrningen har dock ändrats sedan kartan utformades). En bild på strategikartan visas till höger. Exemplet är hämtat från tre böcker (Petri och Olve, 2014a, 2014b; Falk m.fl., 2016), vars författargrupper består av nuvarande och tidigare medarbetare i mitt forskningsområde, som jag också pratat med om fallet under arbetet med avhandlingen för att få fler infallsvinklar på exemplet. Förutom att beskriva hur P\&R 2010 och 2011 arbetade med strategikartan diskuterar jag även strategikartan som bild $i$ termer av dess "kart-het", med vilket jag avser sätten som strategikartan fyller kartrollen och möjliggör navigation genom att den som ska navigera kan identifiera sin position i terrängen kartan visar.

Exemplet. Innan 2009 fanns det inte någon gemensam strategi för P\&R-koncernen, men efter att Jan Roy, som själv arbetat med styrkort $i$ andra organisationer, blev koncernchef för P\&R och VD för Gröna Lund, skedde flera förändringar. Redan 2010 satte arbetet igång med att utveckla ett en strategikarta, och baserat på detta föreslogs senare även ett balanserat styrkort. I början av 2011 kallades samtliga chefer till en kick-off där idéarbetet för att ta fram en strategi påbörjades.

Avdelningarna fick uppdraget att bryta ner strategin på avdelningsnivå, och kunde därmed påverka hur strategin formulerades. Baserat på detta arbete fastslogs ett antal vägval i form av strategiska prioriteringar; vägvalen sammanfattades i ett utkast på strategikarta i powerpoint. Den tidiga versionen av strategikartan var dock "ganska kantig och lite svår att ta till sig för personer som inte deltagit i det tidiga utvecklingsarbetet" (Petri och Olve, 2014b, s. 95). P\&R tog in en illustratör för att ge kartan ett mer överskådligt och lättsamt uttryck i linje med organisationens identitet och vision.
Den färdigställda visuella utformningen av strategikartan anspelade på serietidningar och lekfullhet "för att stämma med koncernens övriga hedonistiska ideal och profil" (Falk m.fl., 2016, s. 55). Till bilden togs även ett manus fram, en "strategiberättelse", som stöd för den som skulle presentera kartan, då kartan inte upplevdes som självförklarande och dessutom som alltför komplex utan en kompletterande förklaring av delarna och sambanden mellan dem (vilket är centralt för strategikartan som koncept och visualisering).

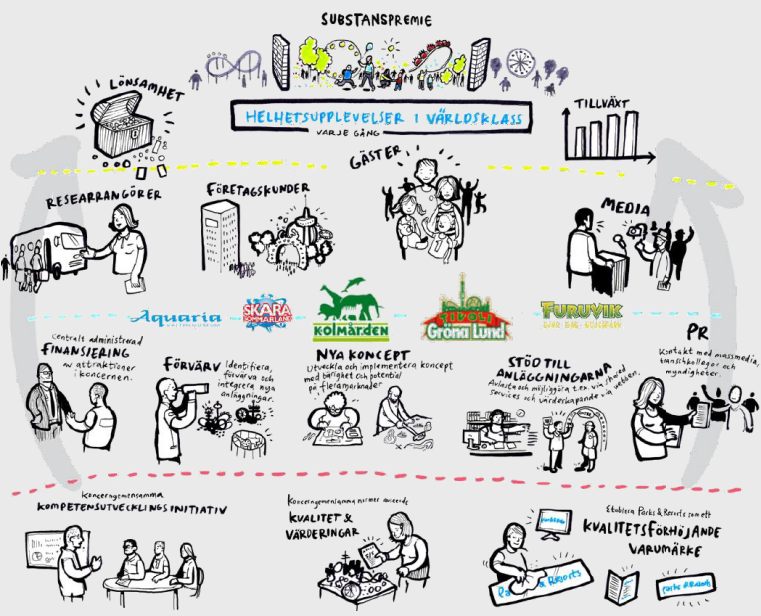

Strategikartan från 2010. Återges med tillstånd från Parks och Resorts.

Användningen av kartan var till en början som ett pedagogiskt verktyg för att förmedla visionen ("Helhetsupplevelser i världsklass"), och där var själva bilden viktig som en del $i$ berättandet. Dessutom låg strategin och strategikartan till grund för att skapa ett styrkort för koncernen med mätetal för att följa upp och styra verksamheten. Dessa behövde kopplas till strategikartan på något sätt. Lösningen blev att uppdatera strategikartan med illustrationer av "termometrar" som placerades vid viktiga områden i kartan, och koppla nyckeltal till dessa.

Diskussion. Redan i titeln på en av Kaplan och Nortons (2000) artiklar om strategikartor ("Having Trouble with Your Strategy? Then Map (t") kan man ana deras syn på valet av kartan 
som modell, nämligen att en kartbaserad bild är ett sätt att tydliggöra och kommunicera vad strategin är och hur ekonomistyrningen hänger ihop med strategin. Därmed kan vi utgå från att strategikartan bygger på en form av "kart-het", och kan användas för navigering. Filosofen Sibylle Krämer (2011) diskuterar kartans användbarhet och att den bygger på principer som indexikalitet, att kunna identifiera sig $i$ kartan, och navigerbarhet, att kunna använda kartan för att ta sig till en viss position. Mer konkret skriver hon att: "The purpose of the map is to make an unfamiliar terrain accessible to a user as a space of movement and action. (...) $[B] y$ means of indexicality, a real person, a user, can transform him- or herself into a virtual point on the map. Only when this latter condition is fulfilled does the map become not only a representational object, but also an instrument for orienting onself for action" (Krämer 2011, s. 277).

Genom dessa begrepp kan vi nu närma oss frågan om bilders potential till "karthet" $\mathrm{i}$ fallet Parks och Resorts strategikarta. När det gäller indexikalitet valde $P \& R$ att involvera sina medarbetare i framtagandet av strategikartan som ett sätt att bryta ner koncernens strategi och välja strategiska prioriteringar, något som ökade möjligheten för medarbetare att identifiera sin egen roll $i$ helheten då de varit med och skapat den. Ett annat sätt var att matcha organisationens identitet, som byggde på lekfullhet och "hedonistiska ideal", med den visuella utformningen av strategikartan, och att därigenom länka samman organisationen och den visuella bilden. Framförallt spelade dock strategiberättelsen en viktig roll för att förklara kartan och bidra till att den kunde användas i organisationen. När det gäller navigerbarhet var den till en början låg eftersom det var svårt att veta hur man låg till prestationsmässigt. En utveckling blev därför att stärka kopplingen mellan strategi, mätetal och den visuella bilden genom att lägga till termometersymboler som indikerade mätpunkter på strategikartan, för att koppla ihop kartan till mätpunkter i verksamheten; därigenom skapades en länk mellan dessa domäner.

De ovan beskrivna lösningarna kan tolkas som länkar mellan de två språken redovisning och visualitet genom strategikartan. Till skillnad från siffror, som kan göra det svårare för medarbetare att "hitta" sig själva i aggregerade data (t ex Bloomfield, 1991) möjliggjorde den visuella utformningen och processen att skapa och använda artefakten fler former av indexikalitet genom delaktighet och kopplingar till identiteten.

Fallet illustrerar dock även utmaningar i processen att skapa och använda en visuell artefakt i mötet mellan två språk, den visuella strategikartan och de sifferbaserade mätetalen i ekonomistyrningen. Framförallt visar fallet att det förekom kompletterande överlappningar mellan dessa språk: det visuella användes för att förtydliga strategin och skapa en idé om samband mellan verksamhetens områden och visionen; samtidigt visade sig kartan inte vara självförklarande utan den kompletterades med ett skriftligt manus och senare av termometrar med kopplingar till mätetal. Vi har alltså att göra med ett exempel på samspel mellan det visuella (strategikarteartefakten) och det som den bygger på, och utvecklar (det ekonomiska).

\section{Källor}

Bloomfield, B. P. (1991) "The role of information systems in the UK National Health Service: Action at a distance and the fetish of calculation", Social Studies of Science, 21, s. 701-734.

Falk, T. m.fl. (2016) "Att beskriva organisationers strategi som en karta", i Nilsson, F., Petri, C.-J., och Westelius, A. (red.) Strategisk ekonomistyrning: med dialog i fokus. Lund: Studentlitteratur.

Kaplan, R. S. och Norton, D. P. (2000) "Having Trouble with Your Strategy? Then Map It", Harvard Business Review, 78(September-October), s. 167-176.

Krämer, S. (2011) "The Mind's Eye: Visualizing the Non-visual and the Epistemology of the Line", i Heinrich, R. m.fl. (red.) Image and Imaging in Philosophy and the Arts, Vol. 2. Frankfurt: Ontos Verlag, s. 275-293.

Petri, C.-J. och Olve, N.-G. (2014a) Balanserad styrning: utveckling och tillämpning i svensk praktik. Stockholm: Liber.

Petri, C.-J. och Olve, N.-G. (2014b) Strategibaserad styrning: så använder du strategikartor och styrkort för att nå organisationens mål. Stockholm: Liber. 
undersöks utifrån dess effektivitet som underlag för att fatta beslut. I denna litteratur har bilders roll för att synliggöra och tydliggöra information varit en återkommande fråga (Janvrin, Raschke och Dilla, 2014; Bačić och Fadlalla, 2016). Jämförelser mellan olika format, såsom tabeller och grafer, är vanligt för att försöka avgöra vilket det bästa sättet att gestalta redovisningsinformation är så att rätt beslut kan fattas. Olika formats användbarhet bedöms utifrån utfall i fiktiva beslutsfattandesituationer (t ex Dickson, DeSanctis och McBride, 1986; So och Smith, 2002; Cardinaels, 2008), och studier tenderar att visa att grafiska format kan förbättra beslutskvaliteten (mätt i andel korrekta svar på enklare uppgifter). Ett exempel på tillämpning av dessa frågor inom ekonomistyrning förekommer i en studie av Arjaliès and Bansal (2018), som beskriver kapitalförvaltares användning av emojis för att förmedla egna och tolka kollegors attityder till olika investeringsmöjligheter. De visar att emojis, till skillnad från siffror, kan förmedla känslor och attityder. Att använda visuella format för att formulera rekommendationer möjliggjorde därmed att förvaltarna fick ytterligare information att utgå ifrån i sina investeringsbeslut. I likhet med rapporteringslitteraturen bygger studier om informationsanvändning i beslutsfattande på antagandet att visualisering kan synliggöra information och skapa kognitiva fördelar i beslutsfattandet, även om individuella skillnader och erfarenhet av att använda olika typer av information är aspekter som lyfts fram som minst lika viktiga som formatet i sig (se t ex Cardinaels, 2008).

\section{Förklaringsmodeller för visualitetens roll i redovisningen}

I denna avhandling föreslår jag, med stöd i tidigare beskrivningar (Gallhofer och Haslam, 1996; Davison och Warren, 2009) att visualitet i redovisningen kan förstås i termer av överlappningar då det visuella i ökande grad integreras med andra informationsformat (Meyer m.fl., 2013). Syftet med detta avsnitt är att sammanställa och diskutera tidigare litteratur utifrån ett urval av förklaringar som förekommer avseende visualitetens roll i redovisning, och att sedan jämföra dessa som ett sätt att konceptualisera överlappningsperspektivet.

Men först behövs en förståelse av vad som menas med överlappning - vad är det som överlappar när två "språk" (Davison och Warren, 2009) eller "former av vetande" (Gagliardi, 1996) kombineras? I min läsning av litteraturen har jag noterat att det förekommer flera olika "förklaringsmodeller" av hur det visuella förhåller sig till redovisning. Exempelvis förekommer antagandet i exempelvis impression management-litteraturen att det visuella främst är till för att förstärka

eller illustrera data. Å andra sidan finns även förklaringar som bygger på att det visuella är mer än huvudsakligen utsmyckning (Graves, Flesher och Jordan, 1996; Justesen och Mouritsen, 2009; Davison, 2014) utan spelar en representativ och kommunikativ roll, vilket alltså av vissa författare konceptualiseras med hjälp av en överlappningsmetafor. Med andra ord skiljer sig synen på visualitetens roll i 
att konstruera bilden av organisationen, och olika förklaringsmodeller för överlappningar förekommer sida vid sida i redovisningslitteraturen. I följande avsnitt diskuterar jag tre förklaringsmodeller för överlappning mellan visualitet och redovisning.

För det första noterar Guillet de Monthoux (2004) att de estetiska principerna spontanitet, skönhet och kreativitet ofta framställs som motsatser till ordning, regler och rutiner i organisationer, vilket kan tolkas som ett motsatsförhållande mellan å ena sidan det rationella och strukturerade som ofta förknippas med redovisning som språk (jfr. Graham, 2013), och å andra sidan det visuella och estetiska. I linje med detta skriver Davison och Warren (2009, s. 847) att det visuella "motstår definitioner" och "översättning i kvantitativa termer" samt att det är ett långt "hopp" mellan den ekonomiska vetenskapens "hårda" epistemologi och det visuellas "mjukare" språk som hämtar inspiration från exempelvis konsthistoria och kulturstudier. Här finns alltså en idé om en kontrast mellan det visuella (och kopplat till det, konsten och det estetiska) och det ekonomiska (och kopplat till det, mätbarhet och kvantifiering). I redovisningslitteraturen förekommer ibland uttalanden om en separation mellan det visuella och själva redovisningsinformationen.

Ett exempel är Anthony Hopwoods (1996, s. 55) inledning till AOS specialnummer om visualisering i årsredovisningar, där han gör skillnad på "accounts themselves" och "the changing documentary contexts in which they are set", vilket indikerar en åtskillnad mellan vad som är redovisning och hur den förmedlas, där det sistnämnda främst framställs som en paketering av redovisningen. Liknande tankar återkommer i impression managementlitteraturen som undersöker visualitet utifrån hur nära det motsvarar den underliggande informationen (som ofta är sifferbaserad), där det visuellas roll i redovisningskommunikation kan vara att illustrera eller förstärka budskapet (t ex Brennan, Guillamon-Saorin och Pierce, 2009) utan att utgöra ett eget budskap. Baserat på dessa beskrivningar tolkar jag in ett antagande att det visuellas roll $\mathrm{i}$ redovisningen är att fungera som redovisningslogikens förlängda arm, snarare än att fungera som eget språk; därför föreslår jag att benämna denna förklaringsmodell "Separation" eftersom relationen mellan visualitet och redovisning antas bygga på att redovisning är separat från visualitet.

Ett andra perspektiv på visualitetens roll i redovisning utgår istället från att det finns en överlappning. Gagliardi (1996) föreslår exempelvis att en strikt uppdelning mellan estetik och rationalitet främst är en produkt av modernitetens idé om den rationella, effektiva organisationen där det inte finns utrymme för subjektiva, estetiska upplevelser. Gagliardi noterar dock att upplevelsen av organisationen, en rationell entitet, också har estetiska drag, speciellt sett ur anställdas upplevelser av organisationen som den verklighet de vistas i. I linje med detta presenterar Gallhofer och Haslam (1996) förslaget att redovisning och konst (som är ett perspektiv på visualitet) visserligen är separata, men att de delar 
funktionen som kommunikativa och representativa artefakter och därför kan tänkas överlappa:

\begin{abstract}
While accounting and art function in society as separable and distinct phenomena, they also substantively overlap given their shared character as communicative and representational artefacts.
\end{abstract}

(Gallhofer och Haslam, 1996, s. 23)

Utifrån en idé om överlappning antar Gallhofer och Haslam att det är möjligt att konst och redovisning har liknande kommunikativa funktioner och därmed liknande utmaningar och möjligheter (exempelvis att representationsformen innebär ett maktperspektiv och har en inneboende emancipatorisk potential); utifrån detta drar de slutsatsen att dessa likheter innebär att konst och redovisning överlappar. I artikeln ger de exempel på hur de kan hämta inspiration från varandra och menar att det därigenom kan ske ett utbyte som över tid leder till fler sammansmältningar mellan konst och redovisning. Överlappning i denna bemärkelse handlar alltså om konceptuell likhet och möjligheter till utbyten som på sikt kan öka likheterna. Detta tolkar jag som en form av kombinering där de två områdena över tid utbyter innehåll och på sikt konvergerar på ett konceptuellt plan. Ett mer konkret perspektiv på kombinering framställs av Meyer m.fl. (2013), som pekar på att det förekommer en ökning av integrering av det visuella i andra texter. De skriver:

The increased use of visual elements in the design of texts, such as, for instance, bullet-pointed lists, flowcharts, or network graphs, allows written texts also to acquire an overall visual Gestalt that shapes and informs the meaning of the words it contains.

(Meyer m.fl., 2013, s. 495)

Meyer m.fl. (2013) beskriver alltså hur det visuella kan omforma budskap och skapa en visuell "Gestalt" som också förändrar betydelsen av innehåll genom att kombineras och interagera på samma yta. Det handlar alltså inte om att det visuella agerar redovisningens förlängda arm, utan om en idé att texters mening förändras i och med att de konvergerar med det visuella. Meyer m.fl. ser visuella uttrycksformer som en betydelsefull form för meningsskapande på samhällsnivån eftersom dessa "... contribute to a society's social stock of knowledge and are, thus, part of an objectified social reality" samt utgör former för meningsskapande som "materialize, organize, communicate, store, and pass on social knowledge within particular communities" (Meyer m.fl., 2013, s. 494). Det finns dock samtidigt som de påpekar ett behov av vidare undersökning av den pågående integreringen av visuella och verbala former för meningsskapande eftersom kunskapen om detta ännu är under utveckling (Meyer m.fl., 2013). 
Ett tredje perspektiv på visualitetens roll i redovisningen är att tänka sig att det visuella är en av flera former för att kommunicera om redovisning. En betydande del av litteraturen beskriver visualitetens roll i redovisningen utifrån modellen flerspråkighet, det vill säga att redovisningen kan uttryckas i olika språk, däribland det visuella. Dessa språk antas kunna kombineras utan motsättningar mellan språken. Bell och Davison skriver att:

\begin{abstract}
We wish to highlight the considerable potential of multimodal research in overcoming the binary opposition between linguistic and visual data and demonstrating the affordances of different modes of communication when used in combination.
\end{abstract}

(Bell och Davison, 2013, s. 176)

De föreslår med andra ord att minska fokus på motsättningar mellan visuella och "lingvistiska" format, och istället undersöka hur kombinationer av format fungerar utifrån antagandet att de utgör olika språk för samma sak. Idén om att det vid överlappning är olika språk som kombineras och används parallellt återkommer även i citatet från inledningen av Davison och Warren, inklippt nedan:

... matters relevant to accounting (when not passed over altogether in silence) are communicated in three "languages": numbers, words and visual images.

(Davison och Warren, 2009, s. 846)

Davison och Warren (2009) föreslår att siffror, text och bilder alla är språk som kommunicerar redovisning. Ett exempel på hur skillnader mellan olika format kan manifesteras i text och antaganden är följande citat av Jane Davison, som hör till dem som under många år lyft fram och undersökt visuella perspektiv på redovisningen:

Pictures and photographs are powerful media, and while they might relate less directly to the accounting numbers than do graphs and charts, they relate more directly to the organisations and societies that lie behind accounting statements. They are often carefully crafted images with implicit roles beyond the decorative or representational, and it is important for accountants and organisational stakeholders to be alert to their modus operandi.

(Davison, 2014, s. 22)

Förutom att notera att fotografier bör förstås bättre av forskare och av praktiker som arbetar med redovisning eftersom de har omfattande kommunikativa fördelar så poängterar Davison att det kan finnas skillnader mellan fotografier och grafer, vilket precis som i konvergensmodellen blir en fråga att undersöka för att förstå visualiseringens roller. En skillnad Davison föreslår är att bilder och fotografier relaterar mindre direkt till redovisningssiffror än exempelvis grafer, och mer till organisationer och samhällen bakom och bortom redovisningen. Vidare 
följer även Christine Cooper en kommunikationsbaserad syn på redovisning, och hon noterar följande:

Accounting itself takes the form of a wide range of communicative forms including numbers, tables, graphs, written narrative, pictures, photos and cartoons ...

(Cooper, 2013, s. 242)

I likhet med de aspekter som lyfts av Bell, Warren och Davison - att redovisningen kan uttryckas med många olika format och att visuella format alltså inte är separata från exempelvis siffror - hänvisar Coopers formulering också till ett kommunikationsperspektiv i och med att visuella format tillskrivs rollen som "kommunikativa former". Flera texter, däribland Coopers, utgår från att redovisning handlar om meningsskapande och därmed förstås kommunikation som en central fråga (se även Jack m.fl., 2013). Ett antagande är att visuella format är fördelaktiga för att kommunicera i vissa situationer och att det därför är viktigt att ha flera språk till hands - siffror, ord och bilder.

I texten har jag nu tagit upp förklaringsmodeller för hur visualitet kan förhålla sig till redovisning. Jag visar att det förekommer åtminstone tre synsätt på visualitetens roll, separationsmodellen, konvergensmodellen och flerspråksmodellen. Jag sammanfattar förklaringsmodellerna i Tabell 2 nedan.

Tabell 2. Förklaringsmodeller för relationen mellan visualitet och redovisning: en början till typologi

\begin{tabular}{|c|c|c|}
\hline Namn & Synsätt och fokus i forskningen & Visualitetens roll \\
\hline Separation & $\begin{array}{l}\text { Visualitet och redovisning är separata } \\
\text { former av kunskap och sätt att veta, samt } \\
\text { olika sociala praktiker. Visualitet kan bli } \\
\text { en del av redovisningen om den kan } \\
\text { integreras och omvandlas. Viktigt för } \\
\text { studier av visualitet är hur det visuella } \\
\text { anpassas efter redovisningens regler. }\end{array}$ & $\begin{array}{l}\text { Visualiteten är skild } \\
\text { från redovisningen } \\
\text { men kan förstärka } \\
\text { redovisningen genom } \\
\text { att följa språkets } \\
\text { grammatik och regler. }\end{array}$ \\
\hline $\begin{array}{l}\text { Konvergens } \\
\searrow \downarrow \downarrow\end{array}$ & $\begin{array}{l}\text { Visualitet och redovisning utgör separata } \\
\text { funktioner med många likheter som över } \\
\text { tid kan influera varandra och bli mer lika, } \\
\text { en ny redovisning. Viktigt för studier av } \\
\text { visualitet är vilka grundläggande principer } \\
\text { som konvergerar och hur. }\end{array}$ & $\begin{array}{l}\text { Det visuella är logiskt } \\
\text { och materiellt separat } \\
\text { från redovisningen } \\
\text { men de förekommer } \\
\text { tillsammans och } \\
\text { komplettera varandra. }\end{array}$ \\
\hline Flerspråkighet & $\begin{array}{l}\text { Redovisning kommuniceras med olika } \\
\text { språk som kan kombineras på olika sätt, } \\
\text { men har olika funktioner (affordances). } \\
\text { Viktigt för studier av visualitet är hur } \\
\text { visuella format fungerar jämfört med text } \\
\text { och siffror. }\end{array}$ & $\begin{array}{l}\text { Visualitet är ett av tre } \\
\text { språk för att } \\
\text { konstruera och } \\
\text { kommunicera } \\
\text { redovisning. }\end{array}$ \\
\hline
\end{tabular}


Tabell 2 illustrerar att det finns olika sätt att se på visualitetens roll i redovisning13, som diskuteras kort nedan.

Sett ur en språklig lins kan separationsmodellen beskrivas som att det visuella måste förhålla sig till redovisningens grammatiska regler (Graham, 2013) och därmed "bli" redovisning för att räknas; det finns alltså inte ett eget visuellt språk inom ramen för redovisning enligt separationsmodellen ${ }^{14}$. Det visuellas relation till redovisningen är i denna modell som en resurs för att kommunicera som är väl värd att använda på grund av sättet det lyfter fram underliggande data, men är främst en förlängning av redovisningen snarare än ett eget språk. Ur detta perspektiv utvärderas det visuella utifrån hur det förstärker redovisningen och om det förvränger den rätta bilden genom exempelvis selektivt urval, design av innehållet och felaktig utformning av grafer.

Konvergensmodellen ${ }^{15}$ bygger istället på antagandet om en ökande likhet mellan det visuella och redovisning i bemärkelsen att språken influeras av varandra. Denna lins innebär en förståelse av visualitet och redovisning som alltmer lika. Å ena sidan beskrivs detta mer konceptuellt av Gallhofer och Haslam (1996), som föreslår att konst och redovisning kan ha liknande mål och kan fylla liknande funktioner i samhället, medan Meyer m.fl. (2013) å andra sidan ser en ökande rumslig konvergens i och med att text och bild kombineras och integreras mer; här är istället infallsvinkeln att konvergensen bygger på att formaten alltmer liknar varandra eller kombineras mer. En utestående fråga är dock på vilket sätt dessa format förhåller sig till varandra (Meyer m.fl., 2013), vilket är en viktig fråga för redovisningen med tanke på att visualiteten beskrivits som svårkombinerad med den ekonomiska epistemologin (Davison och Warren, 2009).

Den tredje modellen, flerspråkighet, föreslår till skillnad från konvergensperspektivet att det inte handlar om en sammanblandning av flera språk, utan att redovisningen kan kommuniceras med flera olika språk som har olika fördelar när det gäller att uttrycka redovisningen ${ }^{16}$.

\footnotetext{
13 Dessa förklaringsmodeller behöver inte vara åtskilda. Syftet med sammanställningen är att visa likheter och skillnader mellan dem för att kunna diskutera möjligheter till fortsatta studier utifrån respektive synsätt på visualitetens roll. Det är inte heller rimligt att förvänta sig att förklaringar som presenteras alltid håller sig "inom ramarna" för en specifik modell eftersom modellerna är mina analytiska konstruktioner för att illustrera likheter och skillnader i synen på visualitetens roll och funktion i tidigare litteratur.

14 Vill man anlägga en metafor på detta skulle jag kalla det "krillmodellen" med hänvisning till hur blåvalar enkelt sväljer den mycket mindre krillen och därmed tillfälligt integrerar den som föda; på samma sätt kan det tolkas att redovisningen sväljer det som kommer i dess väg.

15 I Tabell 2 har jag när jag illustrerat konvergens utgått från en typ av konvergens, där separata delar konvergerar i en ny helhet, men det finns som Appelgren (2007) diskuterar i sin avhandling om mediekonvergens flera typer av konvergens, såsom att separata delar konvergerar i en mittpunkt eller att en del integreras med en annan. Detta kan leda till flera olika konvergenser, exempelvis av innehåll, aktörer, marknader, tekniker och tjänster (Appelgren, 2007). Jag återkommer till konvergensbegreppet i Kapitel 5.

16 Ett förslag på metafor för detta är den trehövdade hunden Kerberos som vaktade ingången till dödsriket i den grekiska mytologin, där varje huvud är unikt men hör till samma varelse. Varje språk kan tolkas som ett huvud på samma djur (redovisning), som kommunicerar på olika sätt men ändå hänger ihop på grund av sin koppling till kroppen. Kerberosmodellen framhåller därmed att redovisning kan kommuniceras med olika språk som förekommer sida vid sida även om de kan vara olika sinsemellan.
} 
För att summera avsnittet så innebär de olika förklaringsmodellerna olika syn på visualiteten, och detta får konsekvenser för hur visualiteten tolkas, undersöks och behandlas som fenomen i redovisningsstudier.

\title{
Utestående frågor om visualitet inom redovisning
}

Detta kapitel har illustrerat att det finns en bredd av studier av visualitet inom företagsekonomisk litteratur, och att det visuella inkorporerats i studier både som metod och fenomen, som process och som artefakt. I följande avsnitt sammanställer jag utestående frågor avseende visualitet i redovisningslitteraturen med utgångspunkt i diskussionerna om visualitet i Kapitel 2.

Det första området rör kunskapen om visualitetens roller i redovisningen. Meyer m.fl. (2013) diskuterar behovet av en ökad förståelse av bilders roll som språk i organisationer, och föreslår att ett område värt att utforska vidare är olika visuella format och deras funktioner; de noterar:

\begin{abstract}
It is also important to conduct research that is explicitly concerned with the comparison of different types of visual artifacts. While photographs, paintings, drawings, flowcharts, but also more material forms like architecture and organizational dress, might have a lot in common, they can be assumed to have distinct functions and uses in meaning construction. So far, we know little about such differences.
\end{abstract}

(Meyer m.fl., 2013, s. 522-523)

Det behövs med andra ord fler studier av hur olika visuella format fungerar. Även om visualitet beskrivits som ett underutforskat område i organisations- och redovisningslitteraturen (t ex Davison, McLean och Warren, 2012) så visar dock min litteraturgenomgång att det finns flera tidigare studier av hur det visuella konstruerar bilden av organisationen, exempelvis hur visuella format (speciellt grafer) bidrar till att förmedla information om organisationer i redovisningssammanhang. Även fotografier har undersökts ur flera perspektiv, exempelvis hur VD-porträtt fungerar (t ex Guthey och Jackson, 2005; Davison, 2010) och hur foton konturerar bilden av företags identitet (t ex Davison, 2011) och hållbarhet (t ex Hrasky, 2012). Däremot har dessa format inte jämförts i tillräcklig utsträckning, vilket behövs för att kunna diskutera skillnader mellan olika format (Meyer m.fl., 2013). Dessutom har diagram fått relativt lite uppmärksamhet jämfört med grafer och fotografier (Davison, 2015).

Följaktligen behövs det fler studier som undersöker vilka roller visuella format spelar för att konstruera bilden av organisationen, och deras relation till varandra, och speciellt studier som fokuserar på vilka roller diagram kan spela i att konstruera bilden av organisationen.

För det andra finns ett behov av att förstå överlappningar mellan visualitet och redovisning. Detta kopplas till bilders ökade integrering med andra format, vilket 
beskrivits som underutforskat inom organisations- och mangementstudier (t ex Meyer m.fl., 2013). Studier av överlappningar är något som hittills inte gjorts på djupet, även om resonemang om olika former av överlappningar mellan konst och redovisning som representativa funktioner (Gallhofer och Haslam, 1996) respektive ekonomiska och visuella epistemologier (Davison och Warren, 2009) tagits upp tidigare. I detta kapitel har jag presenterat förklaringsmodeller som förekommer avseende visualitetens roll i redovisningen.

Separationsmodellens förklaring, att visualitet är ett godtagbart format om det följer redovisningens regler, kan göra att visualiteten avfärdas som form för att konstruera bilden av organisationen på ett bredare plan, och möjliga uppslag för fortsatta studier är att fortsätta undersöka och beskriva bildanvändning som strider mot transparens-idealet i finansiell rapportering, samt att arbeta för mer reglering av bildanvändning så att deras funktion för att presentera en sann och rättvis bild av organisationen förstärks. Det finns dock redan ett antal studier som undersökt detta, speciellt avseende grafer.

Flerspråkighetsantagandet, det vill säga att visualitet likställs med andra format, och att bilder ses som konstruerande av bilden av organisationen på samma sätt som siffror eller annan text, är precis som separationsantagandet förhållandevis vanligt förekommande i tidigare studier. En utmaning med antagandet om flera språk är att det förutsätter en redovisning bortom språket, som kan "kläs" i olika format såsom siffror eller bilder - en slags redovisningens "kärna" som inte uppenbart förändras beroende på språket. Det i avhandlingen använda konstruktivistiska perspektivet motsäger delvis detta antagande eftersom redovisningen där beskrivs i termer av både en representerande och konstruerande funktion. Begränsningen i flerspråksmodellen är att inte fästa tillräckligt stor vikt vid den konstruerande aspekten, som är central för förståelsen av redovisning i denna avhandling.

Som komplement till dessa två förklaringsmodeller bidrar jag med ökad förståelse av visualitetens roller i redovisningen genom att bygga vidare på den minst undersökta förklaringsmodellen (konvergens) som grund för diskussioner av avhandlingens bidrag. Därmed bidrar avhandlingen till förståelsen av visualitetens roller i redovisningen genom att beskriva överlappning i termer av tre förklaringsmodeller i detta kapitel och genom att ytterligare utveckla konvergensmodellen för att därigenom öka kunskapen om hur visualitet kan överlappa med redovisningen. 


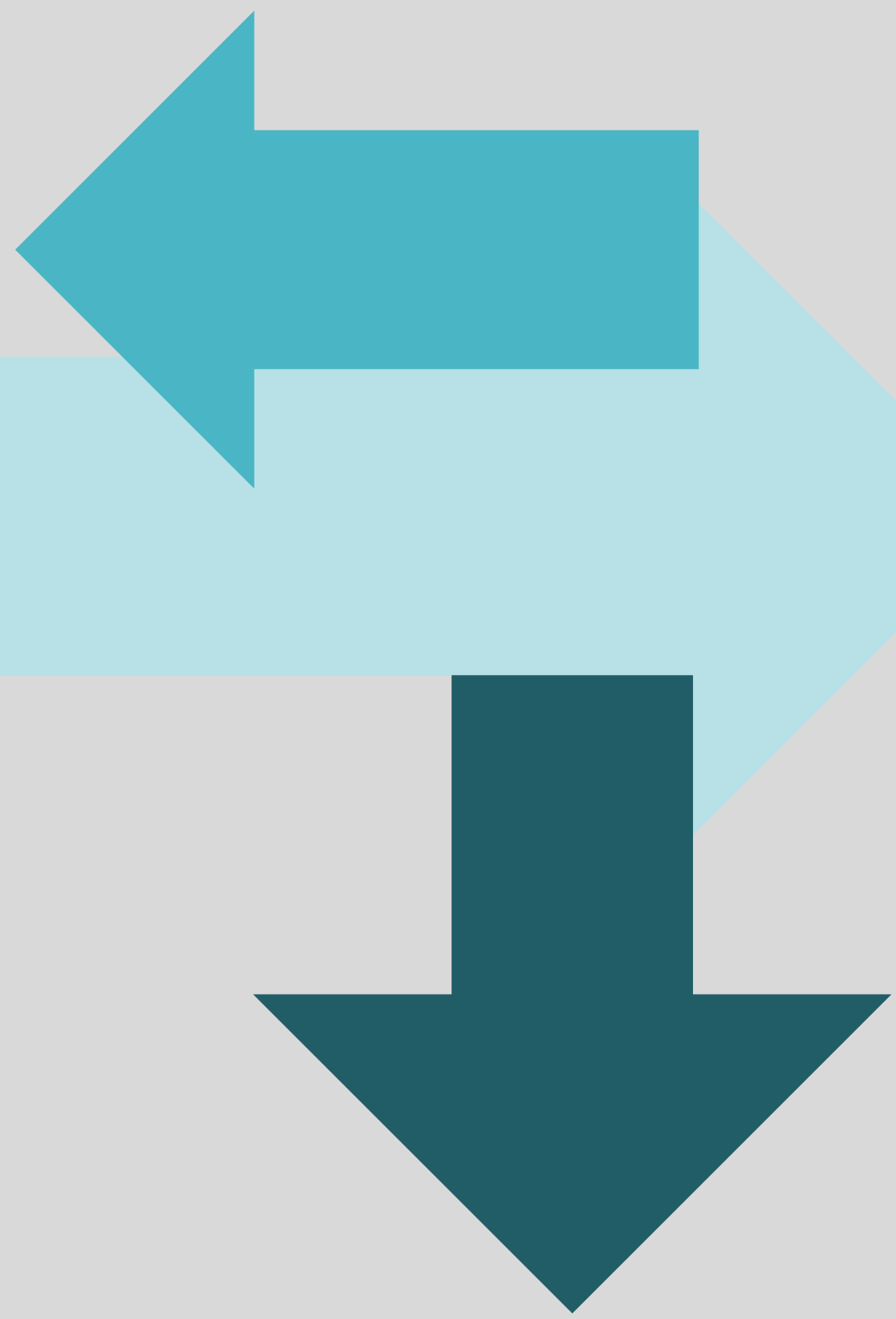

FORSKNINGSMETODER 



\section{KAPITEL 3}

\section{Forskningsmetoder}

Detta kapitel syftar till att beskriva avhandlingens designval och utförande. Jag inleder med en diskussion om mitt förhållningssätt till kunskap eftersom det påverkat val av empiri, forskningsmetod, analys samt val av teoretisk referensram. Därefter summerar jag genomförandet av de delprojekt som ingår i avhandlingen. Jag avslutar kapitlet med att reflektera om hur jag arbetat för att uppnå kvalitet i mitt arbete med avhandlingen och dess delarbeten.

\section{Vetenskapligt förhållningssätt}

Alla förhållningssätt får konsekvenser för hur man kan dra slutsatser om verkligheten, vilket ställer krav på att forskaren tydliggör sin position i förhållande till de tolkningar och slutsatser hon drar från materialet (Scherer, 2009). Därför beskriver jag i detta avsnitt mina teoretiska influenser och hur dessa påverkat hur jag undersökt mitt material.

Avhandlingens övergripande teori om hur världen fungerar är socialkonstruktivism, som är en processmodell över hur samhället utvecklas över tid. Grundläggande för socialkonstruktivismen är förklaringen att samhällets utformning byggs upp genom ett samspel mellan individer som formaliseras i institutioner och språkbaserade gemensamma uppfattningar, vilka inverkar på kommande generationers individer samtidigt som individer i samhället också påverkar de formaliserade institutionerna (Berger och Luckmann, 1966). Som Berger och Luckmann (1966) beskriver institutionalisering genom sociala interaktioner fungerar representationer som tillfälliga tillstånd i en pågående process. Det blir därför viktigt att väga in historiska aspekter och inte betrakta fenomen som isolerade från tidigare skeenden (Hacking, 2005). En viktig del i 
socialkonstruktivismen är de "justifications", det vill säga förklaringar som efterhand byggs upp kring sociala praktiker och konstruerar dessa (Berger och Luckmann, 1966). Detta kan vara till exempel diskurser om ett visst ämne, dokument, invanda handlingar och sätt att göra något på. I och med att uppfattningar sedimenteras i sociala praktiker över tid finns ett värde i att förstå både uppkomsten, uttrycken och konsekvenserna av dessa som ett led i att utveckla en förståelse av olika samhällsfenomen. Baserat på detta föreställer jag mig språket som centralt för meningsskapande. Antagandet att beskrivningar och språk är viktiga överför jag på min förståelse av redovisningen, vilket föranleder antagandet att sociala konstruktioner och deras utveckling och över tid är relevanta att undersöka för att förstå representationer av redovisningen, även de visuella.

Frågan om visualitetens betydelse rör sig i gränslandet mellan texten ${ }^{17}$, aktören och samhället. Detta återspeglas löpande i de metodval jag gjort, och därmed vilket empiriskt material som samlats in och ligger till grund för avhandlingens analyser och slutsatser. Exempelvis undersöker jag i Artikel I visuella affärsmodeller i diagramform för att förstå vilken roll de spelar för att konstruera bilden av organisationen. Vidare gav Artikel II en beskrivning av den historiska utvecklingen av visuella formats roll som "justifications" i kontexten finansiell rapportering över tid i ett enskilt fall. Ett tredje exempel är att Artikel III undersöker betydelsen av konceptet affärsmodell utifrån användarnas egna framställningar av sin affärsmodell. Studien använder ett socialkonstruktivistiskt perspektiv på affärsmodeller, vilket skiljer sig från det i affärsmodellslitteraturen mer vanliga synsättet att affärsmodellen är forskarens lins för att studera organisationer. Mitt alternativa synsätt möjliggjorde en ny förståelse av affärsmodeller som grunden för en diskursiv bild av organisationen. Ett sista exempel är Artikel V, där jag studerade tre olika fall för att kunna jämföra dem och därmed förstå sociala strukturers och kontexters betydelse för en visuell artefakts funktioner i ekonomistyrningen.

Som huvudprincip har min socialkonstruktivistiska ansats operationaliserats genom semiotik, som är en diskursteori (Winther Jørgensen och Phillips, 2000). Valet föll på semiotiken eftersom den möjliggör studier av det visuellas roll som meningsbärare i kommunikation. I min tolkning kan en kommunikationsprocess undersökas både på ett konkret plan genom att studera direkta interaktioner, men också genom ett bredare perspektiv på symboler, organisationer och institutioner. Det är det sistnämnda sättet som används i avhandlingen. Användningen av semiotik som lins för att förstå visuella texter inspirerades huvudsakligen av den franska kulturfilosofen Roland Barthes, som genom reflektioner om specifika symboler, texter och händelser i franskt kulturliv beskrev mening på nivån av bredare kulturella och samhälleliga mönster i uppfattningar.

17 I linje med diskursteori använder jag "text" för alla producerade diskursiva artefakter, även visuella. 
Som Davison (2011; Bell och Davison, 2013) påpekar så finns det mycket hos Barthes som kan belysa redovisningens representationer (speciellt visuella) även idag. Hennes förespråkande av Barthes kan kopplas till en större strömning i redovisnings-litteraturen att inspireras av franska tänkare. I en genomlysning av denna utveckling beskriver Chiapello och Baker (2011) hur framförallt Foucault men även bland andra Bourdieu, Derrida, Baudrillard och Barthes inspirerat det kritiskt-tolkande teoretiska paradigm som bidragit till att bredda förståelsen av redovisningen som praktik och dess roll i samhället ${ }^{18}$.

Jag har i huvudsak läst Barthes som tolkande kultur- och litteraturkritiker, snarare än den enligt Culler (1983) vanligaste synen på Barthes som strukturalist. Culler påpekar dock att Barthes har lästs på flera, ofta motstridiga, sätt, exempelvis både som strukturalist, poststrukturalist och företrädare för franskt kultur-avant garde. Barthes texter täcker in många typer av analyser, och en ständig självkritik mot tidigare texter (Culler, 1983). Barthes kan därför med fördel läsas som en reflexiv analytiker, vars tekniker inte är absoluta analyssystem utan en samling tankesätt för att förstå kulturer, litteratur och visuell kommunikation. I följande avsnitt beskriver jag de viktigaste influenserna i mer detalj.

För det första har idén om kulturanalys från Mythologies (Barthes, 1957), där Barthes resonerar kring franska samhällssymboler såsom bilar, vindrickande och brottning, hjälpt mig att tänka på texter som symboliska uttryck ${ }^{19}$ för en viss kultur. Jag har sedan applicerat denna idén som en lins för att tolka uttryck i rapportering som gemensamma uppfattningar och symboler, exempelvis i fallet att finansiella organisationer verkar föredra att framställa sig som förtroendeingivande institutioner genom att inkorporera byggnader som symboler för stabilitet och soliditet i sina affärsmodellsdiagram (Artikel I).

Ytterligare en text jag återkommit till är Barthes analys av en pastareklam i Rhetoric of the image (Barthes, 1964), vars enskilda symboler (t ex tomater, pasta, färgskala) analyseras, och sedan tolkats på helhetsnivån som ett uttryck för "italianicitet". Jag har läst denna text flera gånger och inspirerats av Barthes approach till djupanalys utifrån analyser av enskilda symboler och övergången till förståelsen av bilder som helhet i relation till kulturella symboler och sociala konventioner. Detta har jag exempelvis tillämpat när jag analyserat hur olika typer av identitetssymboler (t ex planeter, kablar, rymden) kan stå för ett företags identitet i Artikel II, eller när jag tolkat det som att affärsmodellsdiagram kan ha

\footnotetext{
18 Chiapello och Baker beskriver utvecklingen på 1970- och 80-talet: "The importation of French theory into English language accounting research appears to have taken place at a time when a new way of doing research was being constructed (i...), and this timing seems to have been crucial in terms of establishing the parameters of the new field." (s. 141). De beskriver hur Anthony Hopwood, som vid denna tidpunkt var chefredaktör för AOS, var på jakt efter nya paradigm i redovisningen, och som ett led i detta bjöd han in sociologen Peter Miller för att beskriva franska teoretiker för redovisningsforskare. Detta inspirerade till fler interdisciplinära synsätt som fortsatt att påverka redovisningsfältets utveckling fram till idag.

19 Som titeln på boken där dessa texter förekommer antyder ser Barthes dessa som myter. Myt ska dock, som Barthes-kommentatorn Culler (1983) påpekar, inte tolkas som att en myt är en "delusion to be exposed" (s. 33), utan det handlar främst om delade kulturella uppfattningar.
} 
olika komponenter men också en viss helhetslogik (till exempel transaktionslogiken) som liknar andra diagram, trots att delarna i dessa diagram skiljer sig åt. Med andra ord har jag med inspiration från Barthes analys i Rhetoric of the image genom löpande dialog med mitt material förstått både delar och helheter i det.

Även texten Death of the author (Barthes, 1968) har haft inflytande på min förståelse av visuella bilder (t ex i en årsredovisning). Jag har tolkat Barthes diskussioner om avsändarens minskade betydelse som ett exempel på intertextualitet 20 Barthes skriver att en text är "a tissue of quotations" där gemensamma kulturella uppfattningar uttrycks av en viss skapare i en viss text genom att dessa uppfattningar återvinns och återges i texten. Fokus är på de gemensamma uppfattningarna snarare än författaren, som främst återvinner tidigare idéer i sin egen text. Barthes beskriver det på följande sätt:

[A] text is made of multiple writings, drawn from many cultures and entering into mutual relations of dialogue, parody, contestation, but there is one place where this multiplicity is focused and that place is the reader, not, as was hitherto said, the author. The reader is the space on which all the quotations that make up a writing are inscribed without any of them being lost; a text's unity lies not in its origin but in its destination.

(Barthes, 1968, s. 148) ${ }^{21}$

Intertextualitet är alltså en form av "återvinning" av tidigare textproduktion och är med andra ord ett uttryck för rådande normer och uppfattningar i ett samhälle eller i en grupp, vilket kan undersökas i instanser av återvinning. En instans, det vill säga en enskild förekomst av något såsom en specifik visuell bild, antas ur det intertextuella perspektivet kunna stå för en klass av texter eftersom instanser speglar och reproducerar klassens genreregler22. Detta möjliggör att ett material används som källa för att undersöka sociala konventioner på bredare front än i enskilda texter, men det är en utmaning då generalisering om en hel klass baserat på vissa instanser förutsätter att det går att generalisera utifrån dessa. Så var exempelvis fallet i Artikel II där jag undersöker Ericssons årsredovisningar för att dra slutsatser om årsredovisningen (klassen) utifrån användning i ett fall. Min

\footnotetext{
20 Intertextualitet är ett begrepp som förekommit tidigare inom företagsekonomisk litteratur. Bell och Davison sätter exempelvis följande ord på intertextualitet när de diskterar semiotiska perspektiv på bildanvändning: "the way in which individuals interpret an image is shaped by their accumulated cultural knowledge and experience of other visual texts that are drawn on and recycled to create new images." (Bell och Davison, 2013, s. 176). Det handlar alltså om återanvändning av material.

21 Jag har klippt ut den citerade texten ur ett längre avsnitt hos Barthes för att illustrera min poäng och hur jag använt Barthes text, men det kan poängteras att Barthes efter det inkluderade avsnittet fortsätter med att diskutera sin bild av "läsaren". Han skriver att läsaren saknar historia, psykologi och biografi och enbart ska ses som en idé som håller ihop spåren av mening i en viss text. Detta tolkar jag som ett förslag att inte heller läsaren är en specifik person, utan en del i ett sammanhängande nätverk av mening. Med anledning av min ansats gör jag inte så stor poäng av "läsaridén" i mina analyser, utan jag använder modellen "den tolkande forskaren" som främsta analysapproach. Jag återkommer till detta i nästa avsnitt. 22 Genre avser en social kommunikationspraktik med regler och normer för mening, former och innehåll, som kan utvecklas över tid utifrån att de används (Yates och Orlikowski, 1992).
} 
strategi har där varit att använda litteratur för att förankra mina teoretiska resonemang, exempelvis genom att konstatera att liknande trender också observerats i andra studier, samt att bredda min förståelse av kontexten genom att även undersöka mer material från klassen ${ }^{23}$. Ur ett tolkande perspektiv kan detta ses som att jag löpande uppdaterat min förståelse av visualitet genom att närma mig olika material, vilket guidat min förståelse av de specifika material som används i artiklarna. En stor del av förståelsen, och därmed grunden för att dra slutsatser i avhandlingen, bygger därmed på ett iterativt förhållningssätt (den hermeneutiska cirkeln) både avseende mitt arbetssätt (växlingar mellan olika empiriska material och olika teorier) och hur jag genom upprepade närmanden fått en djupare förståelse av materialet. Utifrån antagandet att generalisering av instanser är möjligt så har idén om texter som intertextuella, det vill säga reproducerande av konventioner, varit inflytelserik för hur jag undersökt och dragit slutsatser om visuella texter i den här avhandlingen.

När jag baserat på ovanstående resonemang använder Death of the author som ingång till visuell tolkning innebär det inte att leta efter den "sanna" betydelsen eftersom texters betydelse alltid är en produkt av tolkning snarare än något absolut (Føllesdal, Walløe och Elster, 2001). Det går alltså inte att med semiotikens hjälp uttala sig om någon absolut betydelse, inte minst för meningsskapande kan ses som ett samspel som uppstår vid kommunikation (t ex Hodge och Kress, 1988; Kress och van Leeuwen, 2006). Death of the author handlar snarare om att förstå de mönster och processer som specifika instansieringar ger upphov till, och innebär en analysstrategi som bygger på att söka efter mönster och jämföra olika visuella bilder (med andra teorier eller andra bilder).

Slutligen har vissa idéer i The third meaning (Barthes, 1970) varit inflytelserika, främst Barthes tankar om bildens (i texten diskuteras stillbilder från en film) oförklarbara och flyktiga intryck som inte direkt kodats in i bilden men som skapar mening hos läsaren - detta är en idé som återkommer i begreppet "punctum" som används för att beskriva det i en bild som fångar läsarens intresse i Barthes (1980) analys av fotografier. Jag provade exempelvis i ett tidigt skede av arbetet med Artikel I ett analysramverk som byggde på denna tanke (en analys av diagram utifrån betydelsekategorierna "obvious" och "obtuse", som Barthes (1970) föreslår). Även om den versionen av artikeln inte blev den slutgiltiga flyttades en del av djupanalyserna som speglade min förståelse av diagrammen in i det som

\footnotetext{
23 Ett exempel på detta är att jag i arbetet med Artikel II parallellt med att skriva artikeln undersökte flera organisationers årsredovisningar, två telekombolag och ett industribolag, för att se om det var likt eller olikt det undersökta fallet. Det visade sig att det fanns många likheter i hur bildspråket utvecklats över tid, även om exempelvis industribolaget var tidigare med att använda konceptuella bilder såsom diagram. Telekombolagen återkom ofta till liknande visuella teman i sina årsredovisningar, $\mathrm{t}$ ex teknik och människor. Detta tyder på att företag i en bransch har liknande "visuella språk", även om det fanns vissa Ericsson-unika symboler som återanvändes (den sammankopplade planeten, som jag diskuterar i min licentiatavhandling, till exempel). Genom dessa jämförelser utvecklade jag en fördjupad förståelse av hur bildspråk använts i olika årsredovisningar och kunde konstatera att slutsatserna som drogs inte var unika för det undersökta fallet, utan att de till stor del kan förstås som en instansiering av bredare trender.
} 
blev den publicerade versionen; med andra ord kan man spåra Barthesinfluenserna även i den färdiga versionen av Artikel I.

\section{Reflektion om material och undersökningsmetoder}

Arbetet i avhandlingen har utförts genom fyra delstudier, som mynnar ut i fem artiklar och bygger på två huvudsakliga metoder och material. De två första studierna (1 och 2) använder främst semiotik och de två sista (3 och 4) utgår från kvalitativa fallstudier. Tabell 3 nedan visar vilket material studien bygger på, och vilka analysstrategier jag använt när jag närmat mig materialet för att dra slutsatser om visualitet i redovisningen; dessa beskrivs mer ingående i de följande avsnitten, där jag även tar upp vilka kvalitetskriterier som kan sättas upp för respektive metod, och hur jag arbetat för att uppfylla kriterierna.

Tabell 3. Material och metoder $i$ avhandlingens fyra delstudier

\begin{tabular}{|c|c|c|c|c|}
\hline $\mathrm{Nr}$ & Empiriskt område & Material & Analys & Artikel \\
\hline 1 & Affärsmodellsdiagram & $\begin{array}{l}246 \text { affärsmodells- } \\
\text { diagram från hemsidor } \\
\text { och årsredovisningar }\end{array}$ & $\begin{array}{l}\text { Textanalys } \\
\text { (innehåll, } \\
\text { jämförande) }\end{array}$ & Artikel I \\
\hline 2 & $\begin{array}{l}\text { Bildanvändning i } \\
\text { årsredovisningar }\end{array}$ & $\begin{array}{l}70 \text { årsredovisningar från } \\
\text { Ericsson (1947-2016) } \\
12 \text { årsredovisningar från } \\
2010-\text { tal ( } 6 \text { fall) } \\
4 \text { intervjuer }(5 \text { h) }\end{array}$ & $\begin{array}{l}\text { Textanalys } \\
\text { (innehåll, } \\
\text { jämförande) } \\
\text { "Rytmanalys" }\end{array}$ & $\begin{array}{l}\text { Artikel II } \\
\text { Artikel } \\
\text { IV }\end{array}$ \\
\hline 3 & $\begin{array}{l}\text { Formulering av } \\
\text { affärsmodells- } \\
\text { konstruktion }\end{array}$ & $\begin{array}{l}3 \text { intervjuer med CFO och } \\
\text { HR-chef ( } 3 \text { h) } \\
\text { Dokument (t ex blogg, } \\
\text { årsredovisning) }\end{array}$ & $\begin{array}{l}\text { Kvalitativ analys } \\
\text { Dokumentstudie }\end{array}$ & $\begin{array}{l}\text { Artikel } \\
\text { III }\end{array}$ \\
\hline 4 & $\begin{array}{l}\text { Användning av } \\
\text { visuella och digitala } \\
\text { styrverktyg }\end{array}$ & $\begin{array}{l}10 \text { Intervjuer }(13 \mathrm{~h}) \\
\text { Observationer och } \\
\text { platsbesök }(7 \mathrm{~h})\end{array}$ & Kvalitativ analys & Artikel V \\
\hline
\end{tabular}

\section{Semiotiska analyser}

I diskursteori, vilket semiotik hör till, är texten i fokus (Börjesson och Palmblad, 2007) eftersom texter speglar sociala praktiker som baseras på språk (Bergström och Boréus, 2018). Textanalys går ut på att tolka texter med målet att öka förståelsen av texten snarare än att identifiera dess absoluta betydelse då någon sådan inte antas finnas, inte minst eftersom betydelsen beror på vilket perspektiv texten undersöks utifrån (Føllesdal, Walløe och Elster, 2001). Som Føllesdal m.fl. noterar finns två huvudspår för tolkning, avsändarens avsikter och olika tolkares perspektiv. Studier av avsändarens avsikter syftar till att ge insikter om texten utifrån dess framställningssituation och avsedda roll, men ger däremot ingen 
förklaring till textens samhälleliga roll och funktioner, vilket är denna avhandlings fokus. Därmed är det andra perspektivet mer relevant att utgå från i de textanalyser som utförs i de semiotiska delstudierna. Bergström och Boréus (2018) föreslår tre sätt att tolka texter efter att de lämnat framställaren: den faktiska mottagarens, diskursens och forskarens perspektiv. När det gäller forskarens perspektiv säger denna tolkning visserligen inget om hur väl texten mottas och förstås av de tilltänka mottagarna, men Bergström och Boréus noterar att även den tolkande forskaren kan vara en legitim uttolkare av texten genom att bidra med kritiska och analytiska perspektiv:

\begin{abstract}
Den tolkande forskaren är också mottagare, men en speciell sådan. För det första eftersom hen inte tolkar en text - till exempel en annons - på exakt samma sätt som den som annonsen ursprungligen var avsedd för, här kallad huvudadressaten. För det andra därför att analytikern kan ha ett särskilt intresse, nämligen huvudadressatens förståelse av annonsen; det handlar då alltså om en tolkning av en tolkning.
\end{abstract}

(Bergström och Boréus, 2018, s. 31)

"Den tolkande forskaren" är den huvudsakliga analysmetoden i avhandlingens textanalyser, dock enbart i den första bemärkelsen i citatet, det vill säga att jag tolkar texter ur ett annat perspektiv än den avsedda mottagaren och inte avser att tolka huvudadressatens syn på, eller förståelse av, texten.

Utifrån utgångspunkten att textanalys syftar till att genomföra och presentera rimliga tolkningar snarare än att ge svar på vad som är "rätt" betydelse (Føllesdal, Walløe och Elster, 2001) har jag strävat efter att använda flera olika metoder för att förstå texter - från kvantifierande innehållsanalys till kvalitativ djupanalys för att ge en bredd i typerna av tolkning. För att utveckla en förmåga att analysera bilder, och därigenom agera den "uttolkande forskaren" som föreslår en tolkning av materialet baserat på samhällsvetenskapliga metoder, har jag löpande i det praktiska utförandet av analyser låtit mig inspireras av olika ramverk som klassificerar och beskriver bilder, däribland semiotik och kognitiv psykologi.

Kress och van Leeuwens (2006) visuella semiotik, med fokus på det visuellas "grammatik", har varit en viktig utgångspunkt för hur jag praktiskt operationaliserat semiotiken. Deras grammatik bidrar med analysverktyg och analyslinser för att beskriva bildkomposition, exempelvis givet-nytt-principen, centrum-marginal-principen och typer av diagramstrukturer, vilka är centrala utgångspunkter i analysramverket i Artikel I. Den visuella grammatiken utgör även grunden för kodning av data i Artikel II, då den påverkat vilka kategorier som används vid analys av olika visuella format. Jag har även låtit mig inspireras av kognitionsvetenskap i form av Barbara Tverskys diskussioner om vad som kan ingå i en "graphic display" och hur olika spatiala arrangemang påverkar vår uppfattning av den illustrerade verkligheten. Härifrån har en del av begreppsapparaten som används i Artikel I hämtats, såsom spatiala metaforer (Tversky, 
1997) och hur förändring kan uttryckas i diagram (Tversky, 1997; Heiser och Tversky, 2006). Tankesättet om kompositionens olika delar, som utgör grunden för Artikel I, inspirerades i ett tidigt skede av Tverskys arbete (Suwa och Tversky, 1997; Tversky, 1997, 2011).

För att illustrera hur dessa tankar tillämpats vid analys av mitt material beskriver jag nedan exempel på analysmetoder jag använt. För det första har visuell innehållsanalys använts. Syftet med innehållsanalys är att upptäcka mönster genom att beskriva ett material i kvantitativa termer (Miles, Huberman och Saldaña, 2014). Innehållsanalys används inom båda humaniora och samhällsvetenskap, och möjliggör jämförelser genom kvantifiering av ett utvalt material (Bergström och Boréus, 2018). Metoden går ut på att strukturera ett materials huvudkategorier i relation till forskningsproblemet och sedan kvantifiera instanser av dessa kategorier för att dra breda slutsatser (Boréus och Kohl, 2018) och förstå vad som finns i en specifik samling texter (Prior, 2016). Detta har jag tillämpat för att skapa en bild av ett större material, såsom i Artikel II, där jag undersöker 70 årsredovisningar och klassificerar över 2500 bilder i dessa. Genom att gruppera och kvantifiera användningen går det att se mönster i materialet, såsom att antalet bilder och sidor ökat, och att diagram på snare år blivit vanligare. Innehållsanalysen gav därmed en överblick över förändringarna, men den kompletterades i Artikel II med en analys av årsredovisningarnas framsidor för att förstå hur företagets identitet konstruerats i kombination med att bildspråket fått en större roll i den finansiella rapporteringen.

En ytterligare analysmetod, visuell juxtaposering, innebär en betraktelse av bilder sida vid sida för att upptäcka likheter och skillnader mellan olika visuella artefakter. Ett exempel på sådan analys ges i inledningen, där VD-bilderna från Ericssons årsredovisningar jämförs för att undersöka vilka budskap som olika kompositioner kan förmedla (med inspiration speciellt från Davisons (2010) ramverk för analys av VD-foton). Juxtaposering används även på bredare front för att jämföra och gruppera en samling av affärsmodellsdiagram i Artikel I, där jag klassificerar 246 visuella artefakter utifrån den visuella kompositionen för att upptäcka mönster. Detta mynnar ut i en typologi med fyra grundformer av diagram, vars likheter och skillnader framträdde på helhetsnivån i likhet med Barthes pastaanalys (se föregående avsnitt) genom jämförelse av mönster.

Bergström och Boréus (2018) föreslår att samhällsvetenskaplig textanalys kan utvärderas utifrån ett antal kvalitetskrav, såsom att metoden bygger på en god tolkning av innehållet, ett medvetet val av tolkningsstrategier och -metoder, samt ett noggrant utförande av varje steg. Det handlar alltså inte om att undersöka bilder förutsättningslöst, utan om att utsätta materialet för specifika frågor utifrån ett problem som är av intresse ur ett samhällsvetenskapligt perspektiv. Jag har försökt att uppfylla dessa kriterier genom att exempelvis beskriva premisserna för mina analyser så tydligt som möjligt i de enskilda artiklarna samt i detta kapitel. Syftet med detta är att förklara utgångspunkterna 
för mina tolkningar för att illustrera att de är rimliga i förhållande till de uppställda forskningsproblemen, vilket är det mål för tolkande textanalyser som Føllesdal m.fl. (2001) föreslår. Dessutom har jag i enlighet med rekommendationer för samhällsvetenskaplig analys (t ex Bergström och Boréus, 2018) valt metoder utifrån relevans för det forskningsproblem som undersöks i respektive delstudie, vilket är en förutsättning för att kunna utföra visuell analys på ett systematiskt sätt.

En utmaning för visuell forskning är att visuella perspektiv fortfarande inte är så vanliga inom företagsekonomisk forskning (Boxenbaum, Jones och Meyer, 2018) även om de är vanligare i rapporteringslitteraturen eftersom visuella format ofta används i rapportering (Bell och Davison, 2013). Samtidigt har många personer idag stor erfarenhet av visuell kommunikation, både som mottagare av exempelvis reklambudskap, och som skapare av budskap i visuella medier både i arbetet och privat. Det finns därför en bred praktisk kompetens avseende framställning och tolkning av bilder, och bilder är något som många kan relatera till. En fördel är att bilder, till skillnad från skriven text, ofta skapar "direkta" helhetsintryck som kan göra dem mer övertygande (Davison, 2013; Meyer m.fl., 2013). Samtidigt innebär det att bilder så snart de visas får en betydelse hos publiken, som tolkar den utifrån sin egen erfarenhet och tolkningshorisonter. Ur detta perspektiv är det både en fördel och en utmaning att som visuell forskare möta en publik av kompetenta praktiker med vana att skapa och tolka bilder i sin vardag - intresset är stort men det kan finnas en förväntan på att av bildanvändning såsom den fungerar i vetenskaplig analys har samma mål och tolkningsmetoder som vardagsanvändningen, vilket oftast inte är fallet. Bildanvändning sett ur den kompetenta praktikerns perspektiv skiljer sig från den vetenskapliga tolkningen av bilden, som utgår från ett på förhand uppställt forskningsproblem och använder teorier som belyser frågan genom ett systematiskt utvalt empiriskt material - detta är dock inte ett unikt krav för bildanalysen utan ett gemensamt drag i samhällsvetenskap i största allmänhet.

Men oavsett hur systematisk tolkningen är bör textanalysen, som jag noterat tidigare i detta kapitel, inte göra anspråk på att fastställa en "absolut sanning". Jag anser i linje med exempelvis Barthes (1968) att bilder saknar inneboende betydelse och att mening uppstår genom användning över tid. Det är därför möjligt (och troligt) att det kan förekomma olika tolkningar av samma material från olika tolkningshorisonter, som alla kan vara rimliga. Precis som vid analys av andra typer av material (t ex skriven text eller siffror) är det i avhandlingen dock inte materialets alla möjliga betydelser som står i fokus, utan den mer specifika betydelsen i relation till forskningsfrågorna som materialen valts för att belysa. Därför fäster jag stor vikt vid att i artiklarna och i den här kappan försöka förklara utgångspunkterna och frågorna som styrt min analys, för att därigenom tydliggöra hur visuella bilders betydelse analyserats och tolkats i just den här avhandlingen. 


\section{Kvalitativa fallstudier}

Avhandlingens delstudier med kvalitativa fallstudier som empiri (3 och 4) undersöker främst visualisering som process och bygger på intervjuer och observationer för att förstå processen att visualisera i redovisningssammanhang. Intervjuer har dock även använts för att fördjupa förståelsen av årsredovisningen genom att prata med framställare av dessa i delstudie 2. Det huvudsakliga syftet med intervjuerna har varit att förstå visualitetens roll i olika organisationer, vilket är i enlighet med Flyvbjergs (2006) syn att fallstudien skapar värde i och med kontextualisering av ett visst empiriskt område. I studierna läggs därför vikt på den kontext där händelser och personer förekommer. Jag har därför främst använt kvalitativa intervjuer på ett reflexivt sätt med öppna frågor och dialog som undersökningsapproach.

Valsiner (2000) påpekar att både kvalitativ och kvantitativ data (såsom enkäter och intervjuer) skapas i samband med att frågan ställs till den svarande eftersom världen inte tidigare beskrivits $\mathrm{i}$ de termer som de ställda frågorna konstruerar. Valsiners poäng är att vi knappast kan beskriva resultat utan att nämna hur data "blivit till". Klein och Myers (1999) påpekar att den tolkande forskningen konstruerar data tillsammans med respondenterna och höjer rent av denna aspekt till nivån "princip" som något den tolkande forskaren bör vara medveten om. Som stöd för detta har jag följt Alvessons (2011) rekommendation att intervjuaren är öppen för att diskutera det intervjupersonen vill berätta utifrån studiens syfte.

En fördel med öppna intervjuer är att det ger möjligheter att "träda in i" intervjupersonens kontextualiserade verklighet för att försöka förstå deras perspektiv. Som vägledning i det öppna samtalet har jag haft nytta av ett par "nyckelfrågor" kopplade till delstudiens syfte, vilka lett till längre diskussioner $\mathrm{i}$ intervjusituationen ${ }^{24}$. Exempelvis blev frågan "Hur gör man en årsredovisning?" en effektiv nyckel för diskussioner om arbetet med att ta fram och designa årsredovisningar i Artikel IV, eftersom de intervjuade då kunde beskriva sin arbetsprocess fritt, och flera ämnen som var relevanta utifrån syftet, såsom samarbetspartners, visuell design, yttre krav samt utmaningar, dök upp spontant i intervjupersonernas svar. Mitt val av öppna frågor speglar mitt åtagande att försöka närma mig visualisering som process ur användarnas perspektiv och fånga in deras kontext genom dialog och tolkning.

Arksey och Knight (1999) beskriver den samhällsvetenskapliga validiteten som att forskningsinstrumentet undersöker det man avser att undersöka, det vill säga att metoden fångar in det avsedda empiriska området och att intervjuerna täcker in alla aspekter som är relevanta utifrån forskningsfrågorna, det vill säga

\footnotetext{
24 Jag förberedde också en längre lista på frågor som backup ifall det inte skulle fungera, men har haft turen att de flesta intervjupersonerna helt eller delvis diskuterat ganska öppet kring sina erfarenheter med nyckelfrågorna som grund, och jag har därför inte behövt använda intervjuguiden på alla intervjuer.
} 
att inget missas på grund av att det inte tas upp under intervjun trots att det hade varit relevant för studien. I intervjusituationerna har detta hanterats genom öppna frågor utifrån studiens syfte, med möjlighet att gå till min detaljerade intervjuguide vid behov (se fotnot 24). En utmaning med att intervjufrågorna varit relativt öppna är dock att intervjupersonen då kan ta upp frågor som är intressanta för dem men inte för studiens specifika syfte. Dock har intervjutillfällena pågått tillräckligt länge (ett annat kriterium) att det är min uppfattning (ibland uttalat delad med intervjupersonerna) att vi under intervjuerna täckt in det som beskrivits som syftet. Jag har även tagit det som ett tecken på att ett ämne behandlats uttömmande när intervjupersonerna vänt sig till mig och bett om nya frågor eftersom de själva inte kommit på mer att säga om nyckelfrågorna. Då har jag gått igenom mina förberedda frågor och stämt av vad vi ännu inte pratat om, och ställt dessa frågor innan intervjun avslutats. I ett fall under delstudie 2 var vi vid slutet av intervjun ense om att vi inte var klara med ämnet, och då bokades en ny intervju in för att få tid att stämma av fler frågor. Med andra ord har den delade uppfattningen om tillräcklighet utgått från syftet jag beskrev inför intervjun.

\section{Reflektion om avhandlingens metoder i relation till bidragen}

Arbetet med avhandlingen började 2015 med att jag undersökte affärsmodeller - men utan koppling till det visuella. Jag upptäckte dock under förberedelserna av den studien att det förekom många sätt att visualisera affärsmodeller i årsredovisningar. Det gjorde mig nyfiken på varför företag väljer så olika sätt att representera sig i grafiska format, och väckte frågan om vad en förståelse av visualitet kan visa om premisserna för hur företag beskriver sig. Detta blev startskottet för den här avhandlingen. Men även om avhandlingsarbetet som sådant påbörjades 2015 kan mitt intresse för visualitet och visuell kommunikation spåras längre tillbaka, exempelvis till tiden på sektionstidningen under utbildningen, och senare min yrkesroll som leankonsult då jag deltog i att skapa gemensamma och styrbara bilder av verksamheten med bland annat visualiseringstavlor. Att just jag skulle snubbla på en fråga om bildens betydelse för att representera organisationer är kanske alltså mer oundviklighet än slump.

Med en bakgrund som visualiseringsförespråkare bygger mitt förhållande till forskningstemat på känslan att visualisering är ganska oproblematiskt (men intressant) och framförallt att visualisering är något bra ur kommunikationssynpunkt. Det har visat sig att många - både praktiker och forskare - delar min uppfattning att visualisering kan ha en positiv effekt i organisationer, men med tiden har jag också försökt nyansera min förståelse genom de metodval jag gjort under arbetets gång. Som Føllesdal m.fl. (2001) påpekar är det dock omöjligt att inte ha någon form av samlad "horisont" av kunskaper och sätt att närma sig världen, och det är heller inte målet att forskaren ska göra sig av med denna horisont. Reflexiva metoder kan vara ett sätt att bli medveten om sin egen 
kunskap i förhållande till ny input. Ett dialektiskt förhållningssätt till teori, empiri och den egna tolkningshorisonten över tid kan bidra till att förståelsen utvecklas, exempelvis genom att, som Scherer skriver, skapa medvetenhet om de egna förutsättningarna och tydliggöra grunderna för analysen:

Essentially, there can be no "objective" interpretation of action as this process is influenced by the researcher's socio-cultural background. Social analysis cannot escape these prejudices, but can only become aware of its roots and can attempt to make them transparent as far as possible.

(Scherer, 2009, s. 38)

Under arbetets gång har jag haft min egen tolkningshorisont och dess utmaningar i åtanke och har därför försökt iterera mellan teori och empiri och mellan avhandlingens breda syfte och specifika forskningsfrågor i de olika artiklarna, för att därigenom uppnå en reflekterad förståelse av visualitet. Jag har försökt ta hänsyn till olika "motperspektiv" för att både nyansera och berika min egen förståelse, exempelvis genom grundliga litteraturstudier av visualitet, som delvis återspeglas i Kapitel 2. Ytterligare sätt som jag utvecklat min horisont för att stärka min tolkningsförmåga är genom möten och dialoger med andra forskare. Varje artikel har utifrån återkoppling, diskussioner, reviews och egna överväganden genomgått en utveckling från grundidén jag hade när jag påbörjade arbetet till den färdiga versionen. Jag har även presenterat mitt pågående arbete på vetenskapliga konferenser för att lyssna på andra forskare och få nya infallsvinklar på mitt material när jag presenterat det. Då min forskning på grund av sin inriktning har tvärfunktionella drag har jag valt att presentera den för olika publiker, såsom managementforskare på konferensen NFF (Nordisk företagsekonomisk förening) vid tre tillfällen (Business model track 2015 och 2017, och Digitalisation track 2019), för svenska ekonomistyrare på Nordisk workshop i ekonomistyrning vid tre tillfällen (2016, 2017 och 2019) för semiotiker på NASS (Nordic Association för Semiotic Studies) under 2019 och slutligen för forskare inom financial reporting på brittiska konferensen FRBC (Financial reporting and business communication) 2018 och 2019. Deltagande på konferenser har lett till input på möjlig förbättring, samt till en ökad förståelse av hur mitt arbete uppfattas av de forskare vars litteraturområden jag vill bidra till. Ett exempel på detta är när jag presenterade Artikel III som föreslår en socialkonstruktivistisk syn på affärsmodeller på NFF-konferensen i Bodø 2017: publikens frågor handlade till stor del om mitt antagande att affärsmodeller inte enbart är ett teoretiskt ramverk för att beskriva empiriska fenomen. Detta såg jag som en anledning att vid nästa omarbetning tydliggöra mina grundantaganden och hur de skiljer sig från rådande normer inom affärsmodellsfältet, och att tydligare förklara vad mitt perspektiv kan tillföra till praktiker och forskare. Därmed har både artiklarnas och kappans relevans för de tilltänka mottagarna via reviews och konferenser som input till reflexivitet, vilket bidragit till avhandlingens kvalitet. 


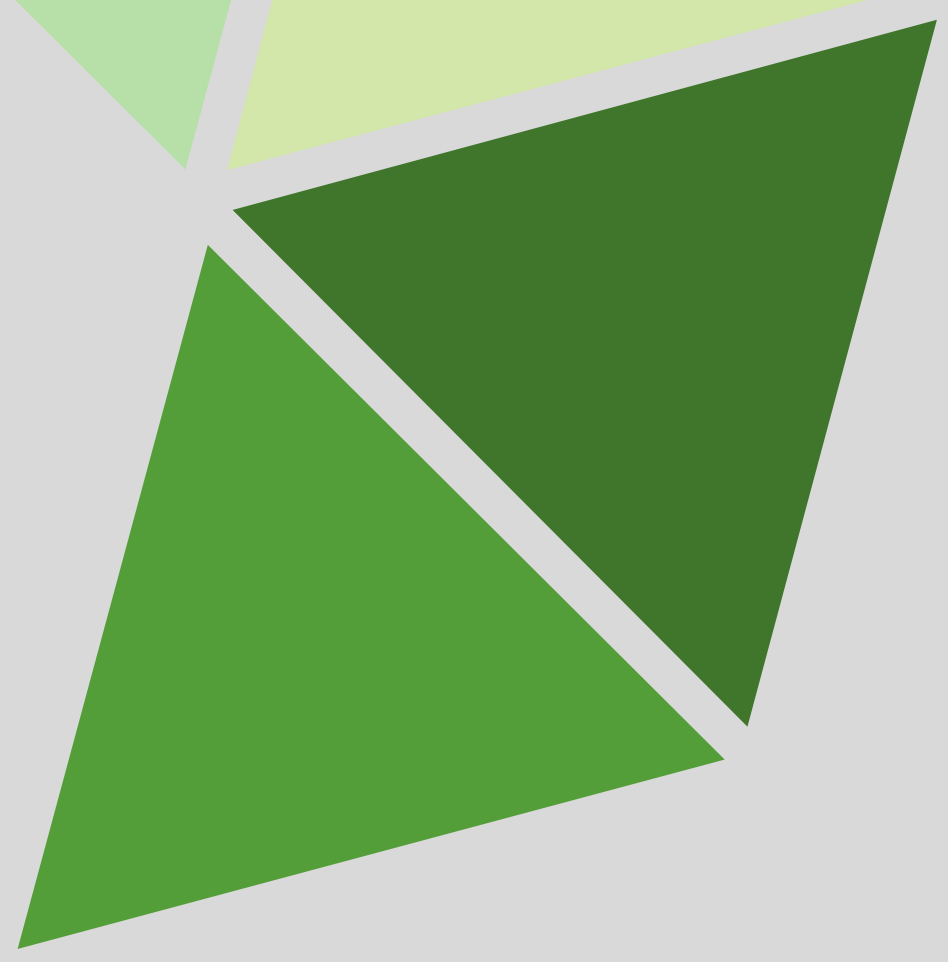

ARTIKLAR OM VISUALITET I REDOVISNING 



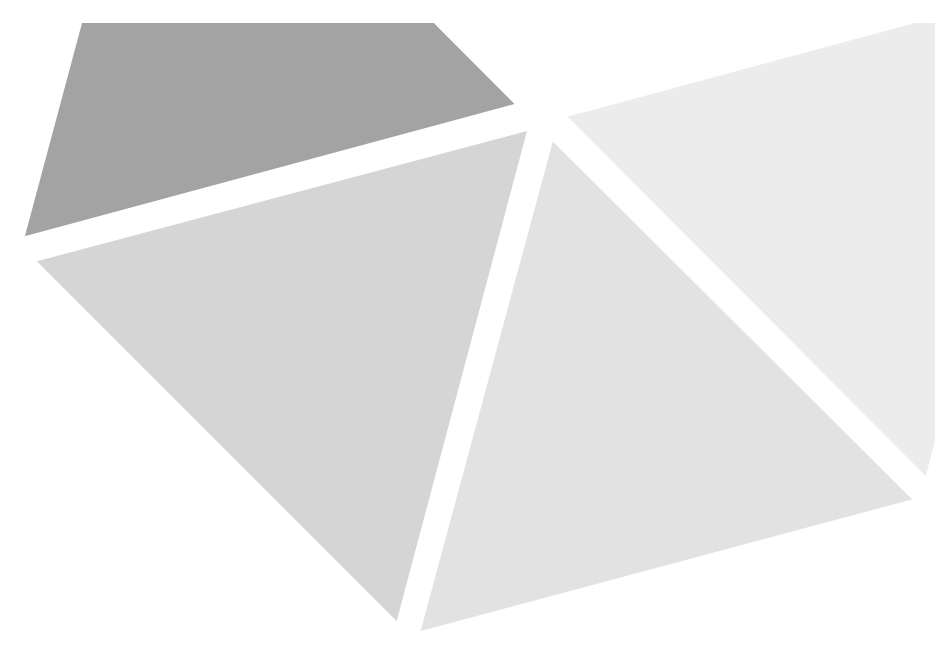

KAPITEL 4

\section{Presentation av artiklarna om visualitet i redovisning}

Här sammanfattar jag avhandlingens artiklar och deras bidrag till att förstå visualitet i redovisningen, samt till målet att bidra till visuell läskunnighet. Jag avslutar med en diskussion om artiklarnas kopplingar till varandra och avhandlingens ämne eftersom detta sätt att utforska syftet varit centralt för hur jag nått mina resultat.

Som jag skrev i inledningen undersöker artiklarna visualitet på bred front i organisationer, främst som styrverktyg och som resurs för att konstruera visuella bilder i finansiell rapportering. Teoretiskt förankras undersökningarna i artiklarna i olika litteraturområden såsom redovisning, kommunikation, operations management och finansiell rapportering. De bygger därmed på problematiseringar inom olika litteraturdomäner. Däremot utgör de på en bredare front olika perspektiv på visualitet och bidrar till behoven av ökad förståelse av visualitet som identifierades i Kapitel 2. Flera artiklar ämnar även bidra till visuell läskunnighet hos personer som interagerar med redovisningsinformation, och jag tar därför upp exempel på sådana bidrag när jag diskuterar respektive artikel.

I de följande avsnitten beskriver jag artiklarna utifrån deras bidrag till en ökad förståelse av visuella bilder och hur bilder bidrar till att konstruera en representation av organisationen som en del av, eller i samspel med, redovisningen. 


\section{Artiklarna och deras bidrag till förståelsen av visualitet}

\section{A visual perspective on value creation}

Artikel I beskriver och undersöker betydelsen av observationen att företag ofta använder visuella bilder (diagram) för att beskriva sig själva genom att visualisera sina affärsmodeller i årsredovisningar och på webbsidor. Affärsmodeller har beskrivits som en berättelse om hur företag fungerar (Magretta, 2002) och hur det skapar värde (Teece, 2010), alltså en självbeskrivning utifrån det som ofta ses som centralt för företag - att skapa värde. En visualiserad affärsmodell har jag därmed tolkat som en form av självporträtt, som förekommer i, och utgör del av företagens redovisningspraktik. Vad kan vi då säga om dessa självporträtt som visuella bilder av organisationen? Vilken bild konstruerar de?

I artikeln valde jag att undersöka dessa frågor genom att analysera en större samling affärsmodellsdiagram. Inom semiotiken avser en samling ett material med semiotiska resurser (i detta fall affärsmodellsdiagram) som undersöks för att förstå dem och deras roll i att kommunicera (van Leeuwen, 2005). En samling av 246 företags affärsmodellsdiagram klassificerades med stöd teorier om konceptuella och processuella diagram (Kress och van Leeuwen, 2006) samt visuella kompositioners funktion i att skapa mening, så kallade spatiala metaforer (Tversky, 1997; Heiser och Tversky, 2006). Sammantaget ledde analysen till en typologi med fyra typer av diagram ${ }^{25}$, som skiljer sig åt avseende graden av "transformationalitet", det vill säga hur de illustrerar förändring. De fyra typer som föreslås är byggstenar, processer, cykler och ett nät av transaktioner. De fyra olika sätten att illustrera affärsmodellsdiagrammet i typologin utgör därmed en visuell bild - en "självrepresentation" 26 - av organisationen utifrån dess värdeskapandelogik. Typologin beskriver för- och nackdelar med respektive diagram, och det poängteras att ett visst diagram lyfter fram vissa aspekter men tystar andra eftersom ingen visualisering fångar in allt som kan ingå i en affärsmodell.

Det går att dra paralleller mellan artikelns resultat till litteraturen om rapportering av intellektuellt kapital (IC), där forskare diskuterat och undersökt affärsmodellen som ett rapporteringsramverk (snarare än ett självporträtt) för att beskriva organisationers intellektuella kapital på ett strukturerat sätt. Bini, Dainelli och Giunta (2016), som utgår från ramverkstolkningen, konstaterar att

\footnotetext{
25 Min klassificeringen av affärsmodeller liknar Täuscher och Abdelkafis (2017) resultat från en artikel publicerad ungefär samtidigt som min. Deras klassificering är dock i mindre skala, men summerar tre typer av affärsmodeller (elements view, transactional view, och causal view) som kan jämföras med mina kategorier byggstenar, transaktioner och processer. De saknar cirkelmodellen, som jag valt att se som en egen logik då den visuellt har en annan struktur och utgår från en annan metafor (cirkularitet, evighet). 26 Jag utforskar begreppet självrepresentation mer utförligt i licentiatavhandlingen för att beskriva visuella bilder som organisationen själv står bakom. Etiketten kan till stor del appliceras på avhandlingens material eftersom det ofta är företagen själva som tillåts konstruera bilden av organisationen. Men detta "avsändarföreträde" är inte skrivet i sten; snarare bör det kunna omformuleras i större utsträckning, inte minst för att uppnå mångfald och olika former av förståelser av organisationen som aktör i samhället.
} 
förväntningarna på affärsmodellsramverket är att lyfta fram relationer mellan olika komponenter och hur de gemensamt skapar värde, men i deras material utnyttjades detta inte speciell mycket. Utgångspunkten för utvärdering i deras studie var huruvida affärsmodellen som ramverk uppfyller sin funktion att strukturera redovisningsinformation snarare än vilken bild den kan konstruera av företaget; det bör noteras att detta utgör en annan typ av förståelse av affärsmodeller i rapporteringslitteraturen än vad min artikel bidrar med.

Sett till målet att bidra till visuell läskunnighet föreslår jag att typologin kan hjälpa företag att "se" sig själva utifrån affärsmodellsdiagram. I linje med Sibbet (2008) som anser att visualisering förstärker samarbete i grupper genom att stötta kommunikationen, föreslår jag att affärsmodellsramverket kan användas som ett dialogverktyg för att visualisera alternativa versioner av den egna affärsmodellen, samt för att analysera den om det avsedda budskapet i den tänkta visualiseringen är i linje med diagrammets transformationalitetslogik. Eftersom olika aspekter blir mer eller mindre framträdande beroende på vilken diagramtyp som används kan detta leda till nya sätt att "se" den egna affärsmodellen och att nya möjligheter därmed uppmärksammas.

\section{Visual trends in the annual report: the case of Ericsson}

I och med att Artikel I bidrar med en förståelse att diagram kan användas för självrepresentation, och därmed kan spela en roll för att konstruera den visuella bilden av organisationen, uppstår följdfrågan hur diagram förhåller sig till redovisning, och vilken roll de spelar i konstruktionen av bilden av organisationen på ett bredare plan. Medan jag arbetade med Artikel I och försökte förklara och analysera affärsmodellsdiagram upptäckte jag att det finns mycket skrivet om diagram som visuell resurs (se t ex Blackwell och Engelhardt, 2002 för en litteraturgenomgång), exempelvisvis $\mathrm{i}$ forskningsfältet som ägnar sig åt att undersöka diagrams utformning, möjligheter och användning (Purchase, 2014)27. Men diagrammens roll inom redovisning och rapportering var däremot outforskad. Davison (2015) noterade exempelvis i sin genomgång av visualitet som empiriskt område i redovisningslitteraturen att det endast kommit ut tre texter i kategorin "diagrams and sketches", vilket kan jämföras med 43 artiklar om fotografier, 6 om arkitektur och 1 vardera om kartor och video. Trots att endast få studier finns i redovisningslitteraturen visade dock arbetet med Artikel I att diagram användes i stor utsträckning i många företags årsredovisningar, både affärsmodellsdiagram och andra. Detta ledde till frågan om vilken roll diagram spelar i organisationers rapportering och hur de bidrar till att konstruera bilden av

\footnotetext{
27 Purchases litteraturgenomgång bygger på konferensbidrag från "International Conference on the Theory and Application of Diagrams", som startade 1997. Hon sorterar in studiers intresseområden i nio teman, däribland grammatiska regler för diagram, diagramförståelse (både kognitiva modeller och empiriska undersökningar av nivåer), grafisk läskunnighet samt att översätta information till eller från diagram.
} 
organisationen. För att förstå det visuella nuet tillkom Artikel II med analyser av bilder i årsredovisningar som ett sätt att kontextualisera bildanvändningen idag ur en historisk lins. Jag valde detta perspektiv då den socialkonstruktivistiska ansatsen bygger på att förståelse uppnås genom att studera utvecklingen av fenomen över tid, samt eftersom jag antog att användning av diagram måste vara förhållandevis ny då det 2015 inte fanns mycket skrivet om dessa i redovisningslitteraturen.

Artikel II bygger på kvalitativa och kvantitativa analyser av bildanvändning i Ericssons årsredovisningar sedan 1940-talet. Den valda approachen var att undersöka diagram och jämföra dem med formaten grafer och fotografier - som är mer utforskade i redovisningslitteraturen - för att tillföra en förståelse av diagrammens roll i att konstruera bilden av organisationen i relation till andra visuella format. Jag använde kategorier hämtade från semiotikens beskrivningar av hur foton, grafer och diagram fungerar som visuella resurser, och räknade och klassificerade sedan förekomster av visuella bilder mellan 1947 och 2016 . Ett komplement till denna kvantifierande och jämförande innehållsanalys var att även analysera alla bilder på framsidorna (som i tidigare litteratur har föreslagits visa en viss årsredovisnings viktigaste budskap och fungera som identitetsmarkör) för att förklara hur bildspråket använts för att kommunicera företagets identitet, det vill säga att visuellt konstruera bilden av organisationen.

Figur 3 nedan visar resultatet av innehållsanalysen i form av fördelningen av olika visuella format i Ericssons årsredovisningar under den undersökta perioden.

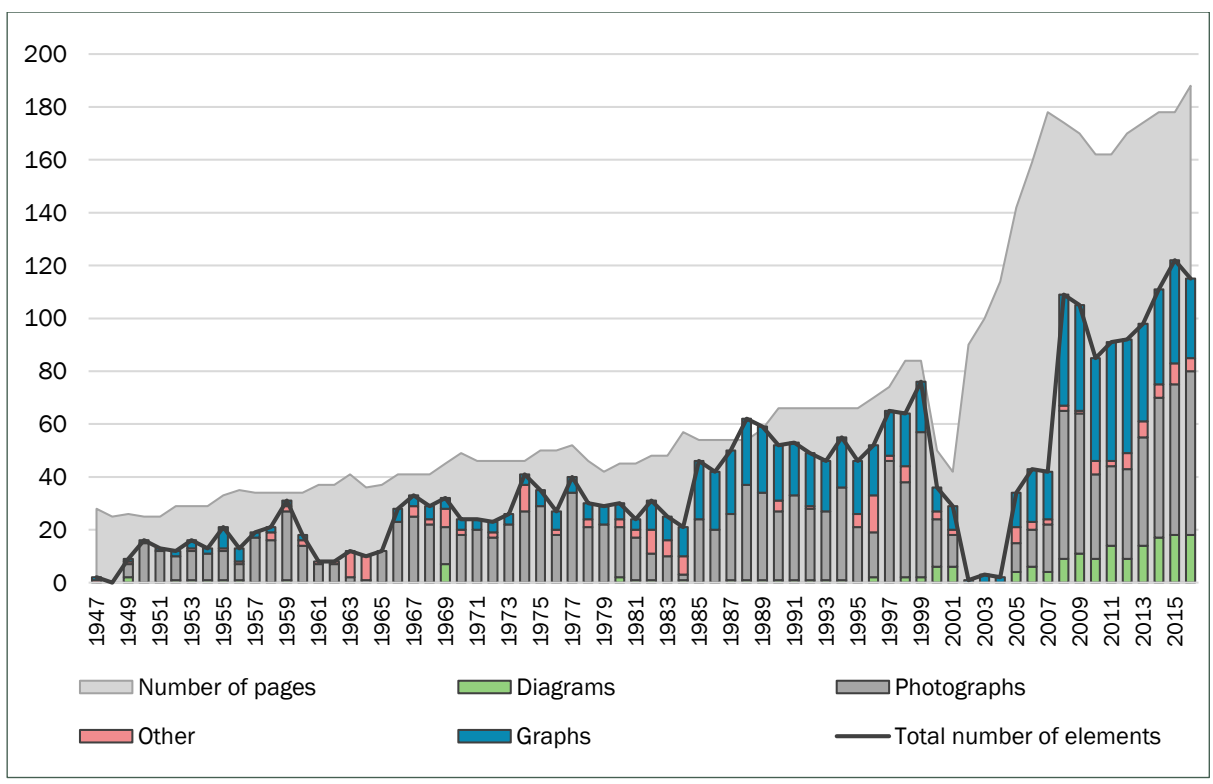

Figur 3. Visuella element i Ericssons årsredovisningar 1947-2016 
Figuren visar att det blivit vanligare med bilder överlag, dock förekom bilder redan 1947 i Ericssons årsredovisningar. Detta följer tidigare studier som beskrivit bildanvändning i amerikanska (Graves, Flesher och Jordan, 1996), brittiska (McKinstry, 1996), danska (Ditlevsen, 2012b) och svenska (Hanner, 1953) bolag över tid, och visat att bildanvändning kom igång ungefär under 1940-talet, och sedan dess har ökat i omfattning. Speciellt intressant är att diagram, till skillnad från foton och grafer (som också ökat i antal men förekom redan på 40-talet), kommit att inta en större plats i årsredovisningen. Detta skedde dock ganska sent i förhållande till bildanvändningen generellt: fram till 2000-talet användes som Figur 3 visar få diagram. Diagram föreslås därför ha blivit en viktigare resurs som i likhet med bilder och grafer fått en delvis förändrad funktion över tid. I tidiga årsredovisningar användes främst kartor, medan årsredovisningarna från 1980talet och framåt använde fler konceptuella diagram, såsom illustrationer av organisationen, affärsmodellen och strategin. Baserat på detta föreslår jag att visuella representationer kommit att ta en större plats i årsredovisningen, samt att det förutom en ökande visualitet i allmänhet också skett en förändring av bilders roll i att konstruera den visuella bilden av organisationen. Utvecklingen har gått från att bygga på det materiella till att utgå från fler generella symboler. Det beskriver jag som en amaterialisering.

\section{Communicating the business model at a Swedish start-up}

Artikel III är ett komplement till Artikel I. Då Artikel I undersökte affärsmodellsvisualiseringar i extern rapportering behövdes en kompletterande beskrivning av hur denna typ av bild (affärsmodellen) fungerar internt, för att kunna reflektera om hur affärsmodellen fungerar som en självrepresentation. I Artikel III undersöker jag därför affärsmodeller ur ett internt perspektiv, med fokus på hur de används som sociala konstruktioner. Dessutom undersöks det externa perspektivet på affärsmodellen kommuniceras externt till investerare.

Genom att undersöka former för att representera affärsmodellen internt och externt visar Artikel III att affärsmodellen skiljde sig både som mental bild hos personer i organisationen, och när den användes på olika platser i organisationen. I det undersökta fallet formulerades affärsmodellen utifrån en arketyp, det vill säga en grundmodell, kallad "hårdvara och mjukvara". Inspiration till modellen hade hämtats från andra branscher, och den gick ut på att sälja en hårdvaru- och en mjukvarukomponent för att på sikt kunna ta betalt för båda. I användningen av denna affärsmodell skiljde sig beskrivningarna avseende om fokus skulle ligga på att få båda delarna att samspela eller om den ena skulle "täcka upp" för den andra sidan utifall att den inte gick lika bra. De flesta beskrivningarna byggde på samma grundarketyp men utförandet av arketypen skilde sig på de olika nivåerna och i användningen internt och externt. Det förekom alltså flera olika bilder inom ramen för samma arketyp, men trots detta var tolkningarna inte i uppenbar konflikt i med varandra utan de samexisterade på olika nivåer. Artikel III bidrar 
därmed med empiriska exempel till affärsmodellsforskningen på affärsmodellens verkningsförmåga som modell (jfr Baden-Fuller och Morgan, 2010) och som social konstruktion snarare än teoretisk lins. Dessutom lägger artikeln grunden för att diskutera olika behov av läskunnighet för olika roller, eftersom den visar att användningen av (mentala) beror på vilken roll användaren hade i organisationen, och vad syftet med representationen var vid användning på olika nivåer.

\section{Get rhythm!}

Bakgrunden till Artikel IV är en observation som gjordes under arbetet med Artikel II, nämligen att det förekommit många olika kombinationer och sätt att placera ut grafer i årsredovisningen. Artikel II byggde främst på metoden innehållsanalys, det vill säga att räkna på förhand bestämda komponenter för att öka förståelsen av bildanvändning över tid. Att räkna bilder har fördelar eftersom innehållsanalysen innebär att mönster kan kvantifieras och observeras på ett aggregerat plan (Miles, Huberman och Saldaña, 2014). Hur och vad som ska räknas i en rapport är dock inte uppenbart, vilket uppmärksammas av exempelvis Husin m.fl. (2012), som ägnar en hel artikel åt att diskutera hur rapportering av intellektuellt kapital i årsredovisningen kan räknas, däribland bilder och grafer (som de föreslår att räkna som 1 per visuellt element). En svårighet i denna typ av studie är att kunna förklara hur bildanvändningen fungerar, eftersom kvantifieringen utgår från att varje enhet har samma informationsvärde oavsett var de befinner sig i texten, vilket går emot Hellman m.fl. (2017) som föreslår att ordningen på presenterad information kan påverka intrycket. Analyser av grafanvändning i rapporteringslitteraturen - inklusive Artikel II - tar i regel inte hänsyn till annat än antal bilder och deras utformning, samt hur de framställer underliggande data genom sin utformning (t ex Steinbart, 1989; Beattie och Jones, 1997; Burgess m.fl., 2008; Laidroo och Tamme, 2016). Överlag har rapporteringslitteraturen därmed svårt att säga något om grafers roll i att konstruera bilden av organisationen mer än att de är bilder som utgör någon form av visualitet.

Baserat på dessa frågor formulerade jag målet för Artikel IV: att komplettera Artikel II genom att utmana förståelsen av grafer som informationsmässigt likvärdiga oberoende av vad de placeras i årsredovisningen. Med inspiration från musikens notationssystem visualiserade jag sekvenser av grafanvändning $i$ årsredovisningar för att undersöka rytmer, och kunde se att detta innebar ett nytt sätt att läsa dessa texter; till exempel verkade grupperingar av grafer på samma sida förstärka upplevelsen av en sifferlogik, medan ensamma stora grafer lyfte fram specifika budskap i texten. I linje med Meyer m.fl. (2013), som föreslår att integrationen av det visuella i verbala texter ökar, så visar min analys av grafrytmer att grafer kommit att bli mer integrerade i övriga delar, och att grafer har gått från att förekomma separat till att presenteras tillsammans med såväl andra grafer som andra format i "framvagnen" av redovisningen, på engelska: också kallat "accounting narrative" (se t ex Beattie, 2014). Genom den visuella 
analysen synliggjordes mönster, vilka jag tolkar som olika sätt att integrera grafer och andra textformat - det vill säga överlappning av format. Därmed bidrar artikeln till behovet (Meyer m.fl., 2013) av studier av det visuellas samspel med andra textformat. Artikeln bidrar även med ett förslag på metodutveckling till rapporteringslitteraturen genom metaforen musikalisk rytm, vilket kan ses som en möjlighet att öka den visuella läskunnigheten i redovisningsfältet med ett nytt sätt att "se" på det visuella som svar på att fler metoder för att undersöka det visuella efterfrågats (t ex Meyer m.fl., 2013).

Som tillägg till att föreslå en ny visuell metod för att undersöka rytmer kompletterades artikeln med intervjuer med producenter och utvärderare av årsredovisningar för att nyansera bilden av grafanvändning ur perspektivet visualisering som process. I mina intervjuer med framställare beskrevs grafer inte främst som ett neutralt representationsformat utan som ett medvetet val för att lyfta fram aspekter på resultatet som organisationen var speciellt stolt över och ville visa. I likhet med Scheja (2009) (se fotnot 8) visar Artikel IV att rapportframställaren inte behöver vara uppsåtligt felrapporterande, utan det kan snarare röra sig om någon som drar nytta av visuella formats direkthet och funktioner som språk för att förstärka information som bedöms vara viktig, vilket är i linje med idén om det visuella som språk för redovisning.

\section{Do employees dream of digital boards?}

Artikel V bygger på en fallstudie av tre organisationer som använder visualisering som en del i sin leanbaserade styrning. I artikeln undersöks visualisering som process med fokus på hur visualiseringen fungerar som styrparadigm, vilket ofta är fallet i lean (t ex Womack och Jones, 2003; Jaca m.fl., 2014; Bateman, Philip och Warrender, 2016). Artikelns empiriska kontext är ett exempel på mötet mellan visualitet (som system för styrning) och redovisningsinformation, eftersom olika former av styrinformation (visuell, textbaserad och numerisk) måste förhålla sig till leans visualiseringsprinciper såsom att synliggöra och tillgängliggöra information. Ur detta perspektiv utgör Artikel V ett exempel på visuella artefakters användning ur ett brett perspektiv eftersom hela styrlogiken har visualisering som utgångspunkt.

Artikeln fokuserar på artekfaten visualiseringstavlor (eller "pulstavlor", som de ibland kallas i Sverige), vilka ofta används i analog form (det vill säga whiteboards) i den dagliga leanstyrningen genom att medarbetare samlas vid den för att diskutera hur det går i verksamheten och lösa problem. Forskningsproblemet i artikeln är vad som händer när dessa tavlor går från analoga till digitala format, och hur styrningen påverkas av en förändring i visualiseringsfunktionerna. För att analysera detta utgår jag från "affordance theory" för att undersöka styreffekter och möjligheter som beror på visualisering respektive digitalisering. Med inspiration från en artikel som utvecklar affordance-begreppet ur ett visualiseringsperspektiv (Beynon-Davies och Lederman, 2017) föreslår jag 
begreppet representationscykler som modell för två faser i arbetet med att ta fram och använda en (visuell) representation, artikuleringsfasen, där man börjar arbetet med att skapa en gemensam bild (artikulation), och manipuleringsfasen, där man använder artikulationer för att uppnå önskade styreffekter. Jag diskuterar empirin utifrån hur digitalisering och visualisering samspelar i dessa faser, och visar utmaningar och fördelar med digitalisering utifrån växelspelet mellan användare, representation och organisatoriska strukturer.

Artikelns analys visar att visualisering spelar en viktig roll för att skapa en gemensam bild av verksamheten, något som redan var på plats i de undersökta organisationerna då de tidigare implementerat lean och visuell styrning. Artikeln visar att olika roller kan behöva använda visualisering på olika sätt; samma ITsystem låg till grund för alla digitala tavlor i studien, men de utformades och användes olika i de tre fallen (exempelvis som underlag för diskussion, som dokumentation eller som verktyg för beslutsfattande) beroende på användarnas behov. Det fanns samtidigt likheter avseende visualiseringens förutsättningar, vilket kan kopplas till att lean som visuellt styrparadigm skapar förutsättningar för en viss typ av styrning. Jag diskuterar i artikeln hur lean fungerade som en ram för visualiseringsprocessen på ett liknande sätt i alla tre fall eftersom de alla använde en tavla för att visualisera viktig styrinformation i samband med möten. Som en följd fokuserade mötena på den information och de mätetal som tidigare lagts in på tavlan, som därmed fungerade som en agenda för mötet och bestämde vilken information som skulle användas och vilka problem som kunde lösas. Detta kan tolkas som att de sociala strukturerna, artikulerade i tavlorna, hade en viss "disciplinerande" makt över informationsanvändningen eftersom styrningen och medarbetarna måste förhålla sig till de format, strukturer och praktiker som formats i samband med att den visuella artefakten utvecklats utifrån lean.

\section{Artiklarnas bidrag till förståelsen av visualitet i redovisning}

I detta avsnitt diskuterar jag artiklarnas bidrag i relation till varandra och avhandlingen som helhet i syfte att belysa hur delarna bidrar till resultatet. Även om delstudierna till stor del är fristående och vänder sig till olika litteraturdomäner så finns det som ovanstående beskrivningar visar flera sammanflätningar mellan dem. Dessa sammanflätningar har spelat en roll för vilka artiklar som ingår i avhandlingen och på vilket sätt de gemensamt målar upp en förståelse av visualitet i redovisning. Därför avslutar jag nu presentationen av artiklarna med att diskutera hur mina slutsatser växt fram genom ett växelspel mellan artiklar, avhandlingsfråga samt mellan teorier och empirin. Figur 4 illustrerar artiklarna och avhandlingens övergripande tema "visualitet i redovisningen" samt de tre typer av sammanflätningar mellan artiklar och avhandlingstemat som bidragit till slutsatserna: direkta kopplingar, kontextualisering och påverkan på eller från det övergripande temat. Jag beskriver dem efter figuren. 


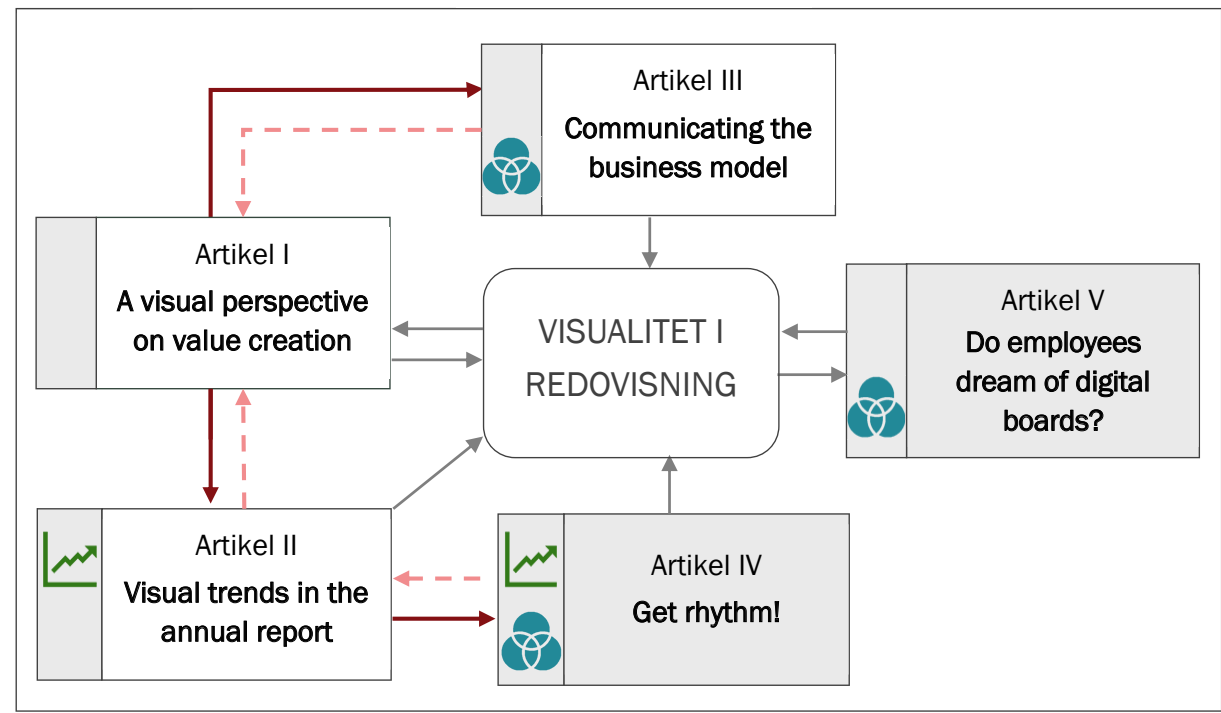

Bidrar till perspektiv

Utvecklingsperspektivet

Överlappningsperspektivet
Typ av sammanflätning

$\longrightarrow$ Direkt inspiration/fortsättning

$----\rightarrow$ Kontextualisering för förståelse av innehållet

Påverkan på, eller från, temat

Figur 4. Sammanflätningar mellan artiklar samt mellan artiklar och det övergripande temat. Vita lådor avser artiklar i licentiatavhandlingen, grå avser tillägg till doktorsavhandlingen.

Direkt påverkan innebär att en observation i en artikel undersökts vidare i en annan artikel, vilket bidrar till en breddning av förståelsen av visualitet $i$ redovisning. Exempelvis var det observationer om den utbredda användningen av diagram i Artikel I som ledde till en önskan att förstå utvecklingen av denna användning över tid, och som därmed ledde till att jag påbörjade arbetet med Artikel II, som har ett longitudinellt perspektiv. I Artikel II kunde jag dra slutsatsen att diagram som resurs ökat i antal och bidrar till att konstruera visuella bilder av konceptuella begrepp såsom strategi och affärsmodeller. Dessa förekom inte i lika stor utsträckning i tidigare årsredovisningar, som istället fokuserade mer på att beskriva händelser under året som gått och de interna produktionsresurserna med hjälp av foton och (delvis) grafer. Dessa lärdomar om diagram som resurser för att konstruera bilden av organisationen på konceptuell basis ökade förståelsen av affärsmodellsdiagrams roll som självrepresentationer i redovisningen, vilket illustreras med en återkopplingspil från Artikel II till Artikel I.

På ett liknande sätt gav observationerna att externrapportering kan stöttas av visuella affärsmodellsdiagram i Artikel I upphov till frågan hur representationer 
formuleras internt och externt, och på vilket sätt affärsmodellen som diskursiv konstruktion rör sig mellan olika nivåer. Detta ledde till Artikel III, som visar att det kan förekomma skillnader i hur bilden av organisationen skapas med affärsmodellsarketyper internt och externt (och på olika nivåer i organisationen). Denna slutsats ledde till en återkoppling tillbaka till Artikel I i form av ökad förståelse av vilken typ av kommunikativ resurs affärsmodellsdiagram kan utgöra, och att affärsmodeller såsom de presenteras externt kan vara ett resultat av en framväxande, och inte alltid entydig, bild av organisationen.

Den tredje och sista pilen med direkt påverkan förekommer mellan Artikel II och Artikel IV. Artikel II började med undersökningen av 70 års bildanvändning i årsredovisningar, där jag även noterade att det förekom olika rytmer i utformningen. För att komplettera förståelsen av visualitetens utveckling ledde denna observation till en djupdykning i rytm-begreppet och bildanvändning $i$ Artikel IV. Resultatet av Artikel IV, däribland att visuella format integrerats mer med varandra och andra textdelar i olika rytmer, ledde till en ökad förståelse av bildanvändning i materialet beskrivet i Artikel II i bemärkelsen att nu kunna "se" att bilder inte enbart skapar mening separat, utan att de också skapar mening tillsammans. Utformningen av kombinationer utgör med andra ord ett sätt att formulera en bild av organisationen i finansiell rapportering. Detta illustreras i Figur 4 med återkopplingspilen från Artikel IV till Artikel II.

Den sista typen av pil är påverkan mellan avhandling och artiklar28. Artiklarna har bidragit till en ökad förståelse av visualitet i redovisningen på olika sätt, i huvudsak till något eller båda av avhandlingens två perspektiv, vilket illustreras med en symbol motsvarande perspektiven bredvid respektive artikel. Pilarnas riktning visar typen av påverkan mellan artiklar och helhetsförståelse. Det första exemplet på detta är Artikel I, som påbörjades med en observation av visualiserade affärsmodeller, vilket blev startpunkten för avhandlingen och dess frågor om visualitet. Ytterligare ett exempel är att de kumulativa insikter om visualitet jag nått efter att jag arbetat med Artikel I-IV ledde till ett behov av att komplettera materialet genom att undersöka visualisering som process - och därmed kunna förstå användandet av visualitet som styrlogik i organisationer. Utifrån detta behov av kompletterande empiri formulerade jag målet med Artikel V, att förstå ett styrsystem som baseras på visualisering och visuella artefakter. Denna artikels bidrag till helhetsförståelsen av visualitet är att visa dess roll som övergripande styrlogik i ekonomistyrningen. Exempelvis visas att användarna inom ramen för den visuella logiken växlade mellan olika format såsom siffror och

\footnotetext{
${ }^{28}$ Här vill jag notera att utformningen av avhandlingen som en sammanflätad helhet inte är det enda sättet att formulera en avhandling. Det vore exempelvis möjligt att dela upp en sammanhängande empiri i olika delkapitel eller -artiklar som visar olika perspektiv på en helhet (se t ex Radits, 2019), eller att inte utgå från helhetsidealet alls, utan att se artikelproduktionen som ett lärandemoment med syftet att presentera ett fåtal högkvalitativa forskningsproduktioner. Men då jag hör till dem som haft sammanflätningsidealet som målbild har jag valt att använda denna approach som utgångspunkt i min avhandling.
} 
bilder utan problem när dessa artikulerats och samlats på visualiseringstavlan. Själva artefakten spelade alltså en roll för att få till konvergens mellan format, men det gjorde även användarnas förmågor, t ex visuell och digital läskunnighet.

För att summera kapitlet så har avhandlingens slutsatser växt fram genom ett växelspel mellan artiklar och det övergripande temat visualitet i redovisning, samt genom påverkan på sekventiell basis mellan artiklarna. Detta kan beskrivas som att avhandlingens slutsatser inte är oberoende av hur avhandlingen som helhet växt fram. Avhandlingen har sedan den första observationen fungerat som en (till en början abstrakt, men över tid alltmer konkret) hållpunkt som fungerat som en röd tråd genom att driva fram fortsatta frågor utifrån avhandlingens övergripande tema. Det är i artiklarna som jag sedan arbetat praktiskt med exempel på visualitet i olika redovisningssammanhang. Jag har sedan återkommit till, och löpande format, helheten, det vill säga avhandlingens slutsatser. Genom detta växelspel växer en förståelse av det visuellas roll i att konstruera bilden av organisationen fram, som jag sammanfattar nedan.

För det första ser vi att alla typer av bilder spelar en allt större roll i redovisningssammanhang då de förekommer i större antal och är mer integrerade med varandra och andra format i årsredovisningen. Detta kan tolkas som att redovisningen i ökande grad inkorporerat visuella resurser för att konstruera bilden av organisationen. Baserat på det undersökta fallet Ericsson är ökningen dock mest tydlig vad gäller diagram, som är den visuella resurs som kommit in senast i årsredovisningen, och som nu förekommer som ett sätt att hantera de ökande kraven på att rapportera mer än siffror, exempelvis avseende intellektuellt kapitel i Storbritannien (t ex ICAEW, 2010; FRC, 2014). Diagram kan kopplas till nya sätt att konstruera bilden av organisationen på ett mer konceptuellt plan, vilket benämns som en amaterialisering av hur bilden av organisationen konstrueras.

För det andra bidrar avhandlingen med exempel på kombinering av visualitet och redovisning ur ett användarperspektiv. I användarsituationen förekom visuella bilder tillsammans med redovisningsinformation sida vid sida för att konstruera en bild av verksamheten på visualiseringstavlan. Detta kan tolkas som att visualitet, förutom att utgöra en form för meningsskapande i organisationer (t ex Gagliardi, 1996; Gallhofer och Haslam, 1996; Meyer m.fl., 2013), också kan påverka verksamheter genom att utgöra en styrlogik som får följder för valet av sätt att representera och använda information. 



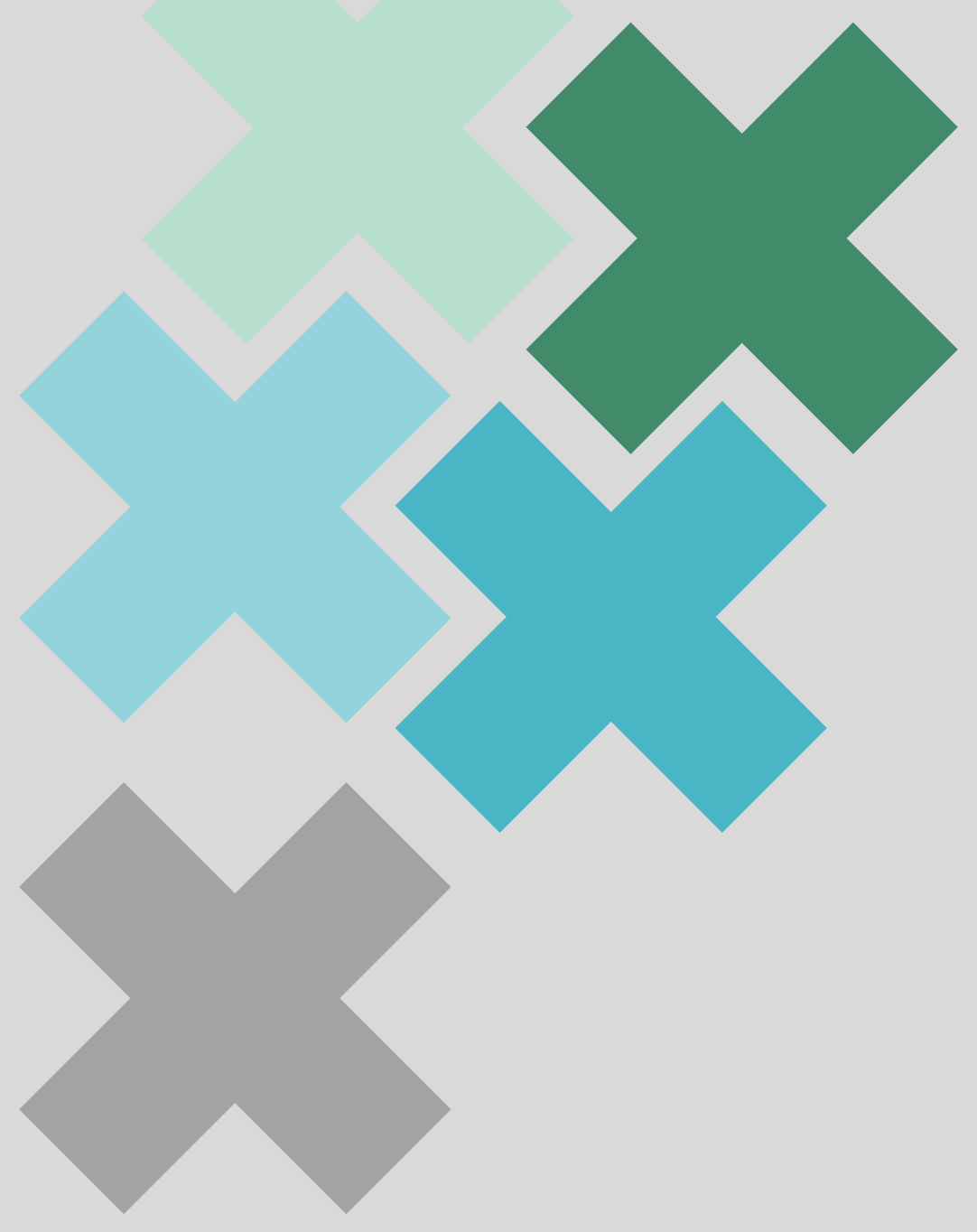

SLUTSATSER OCH BIDRAG 


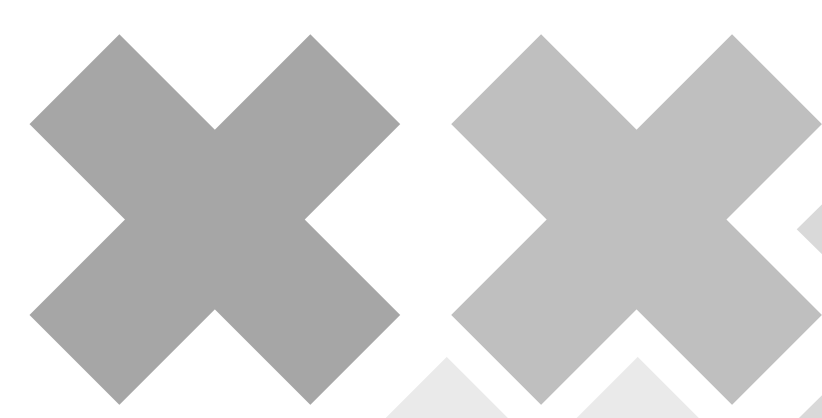

\section{KAPITEL 5}

\section{Slutsatser och bidrag}

Jag har i avhandlingen tagit min utgångspunkt i en pågående utveckling i samhället, ökad visualitet, och undersökt denna utveckling genom att studera hur visuella resurser konstruerar bilden av organisationen. Även om antalet studier som undersöker 'visual management' och 'visual accounting' inom ramen för the visual turn har ökat under de senaste åren noterar Boxenbaum, Jones och Meyers (2018) att det fortfarande finns behov av att öka förståelsen av visualitetens roll i att konstruera bilden av organisationen inom ramen för redovisningen. I linje med detta formulerades syftet med avhandlingen: att föreslå hur visualitet i redovisningen kan förstås.

Inom tolkande studier är en typ av bidrag att problematisera och reflektera om bekanta begrepp och att använda denna reflektion för att uppnå ett frigörande från nuvarande antaganden om världen (t ex Alvesson och Willmott, 1992; Scherer, 2009), för att därigenom bidra till nya tankesätt och sätt att förstå världen (Chia, 2005). Ett bidrag i denna typ av forskning är exempelvis att skapa utrymme för reflektion och förståelse, vilket kan ge upphov till fler frågor snarare än att enbart presentera svar (Bornemark, 2018), vilket är något som genomsyrar denna avhandling i och med att det främsta bidraget är att utöka förståelsen av visualitet i redovisningen genom att utgå från utvecklingsperspektivet och överlappningsperspektivet.

I de följande avsnitten diskuterar jag därför resultaten utifrån dessa två perspektiv. Jag beskriver även hur avhandlingen bidrar till litteraturen samt identifierar förslag på fortsatta studier. Detta följs av avsnittet "praktiska bidrag", där jag beskriver metodmässiga bidrag till utforskning av visualitet i redovisningen, samt till visuell läskunnighet hos praktiker som använder visuell redovisningsinformation. 


\section{Utvecklingsperspektivet}

Denna avhandling visar i linje med ett antal tidigare studier (t ex McKinstry, 1996; Beattie, Dhanani och Jones, 2008; Ditlevsen, 2012b) att mängden bilder i årsredovisningar ökat under 1900-talet. Ett av avhandlingens empiriska bidrag är att ge exempel på att bilderna i ökande grad förhåller sig annorlunda till bilden av organisationen genom att allt mer referera till en icke-materiell och icke-specifik identitet. På 1950-talet användes exempelvis främst dokumentära fotografier för att avbilda händelser under det gångna året, medan diagram och grafer förekom i liten utsträckning. Över tid blev fotografier, diagram och grafer mer ickemateriellt relaterade till organisationen. För denna utveckling använder jag begreppet amaterialisering. När det gäller foton framkommer detta i att de över tid blev mindre förankrade i verksamheten och mer i omvärlden och samtidigt mer fokuserade på önskade, framtida tillstånd snarare än historiska händelser. I diagram visas detta i ett skifte från att använda materiella diagram (främst kartor) till konceptuella diagram, såsom visualiseringar av affärsmodellen. Det visuella har alltså i ökande grad tagit plats som en del av den historia som berättas i det för den finansiella rapporteringen viktiga dokumentet årsredovisningen.

Avhandlingen bidrar med exemplifieringar av denna utveckling genom att diskutera hur valet av utformning utgör olika sätt att konstruera bilden av organisationen. Exempelvis diskuterar jag att olika diagramutformningar (om dessa är medvetna eller omedvetna val hos skaparen kan vara osagt) kan kopplas till olika underliggande logiker avseende synen på affärsmodellen och därmed hur företaget skapar värde. Medan siffror "tvingar fram" kvantifiering, mätning och jämförelser (Graham, 2013), och ord förmedlar budskap linjärt (Meyer m.fl., 2013), så kräver diagram att relationer konstrueras mellan beståndsdelar (t ex Tversky, 1997). Placeringen i diagrammet innebär att komponenterna måste placeras i relation till andra komponenter och att relationer därför oundvikligen konstrueras genom visualiseringen. Artikel I visar att olika konstruktioner av relationer förmedlar olika grundsyn på värdeskapande, och därmed olika sätt att skapa en bild av organisationen.

Diagram är ett område som fått förhållandevis lite uppmärksamhet inom redovisningslitteraturen tidigare (t ex Davison, 2015) men som avhandlingen genom sin utforskning av deras roll i att konstruera bilden av organisationen bidrar till. Idén om den konceptuella bilden av organisationen, som uttrycks i exempelvis affärsmodellsdiagram samt foton som illustrerar en abstrakt idé om organisationen (det vill säga amaterialisering), är ett huvudsakligt empiriskt tillägg till redovisningslitteraturen avseende hur den visuella bilden av organisationen konstrueras i redovisningssammanhang.

För att summera utvecklingsperspektivet så bidrar det med en förståelse av visualitet som ökande i redovisningen, samt att utvecklingen kan förstås i termer av en amaterialisering avseende sättet som det visuella "språket" bidrar till att 
konstruera bilden av organisationen. Framförallt visar jag att visualiteten fyller andra, nya funktioner avseende sättet som bilden av organisationen konstrueras.

Baserat på dessa slutsatser föreslår jag att förståelsen av visualitet utifrån utvecklingsperspektivet medför flera möjligheter till fortsatt utforskning av visualitet i redovisningen. Exempel på områden jag identifierat i avhandlingens artiklar är att använda den visuella logiken som ett sätt att beskriva och illustrera organisationer för att undersöka viktiga mekanismer för värdeskapande (Artikel I), samt att bredda undersökningen av förekomster av amaterialisering till fler företags rapportering och till fler redovisningskontexter (Artikel II).

Vidare föreslår jag att framtida studier fortsätter att undersöka diagram som format för redovisning, vilket hittills är underutforskat inom redovisningsfältet. Ett mönster $i$ avhandlingens material är exempelvis kartors roll $i$ att konstruera bilden av organisationen. Materialet i Artikel I innehåller exempel på att kartor ibland förekom under beteckningen "affärsmodell" hos företag i råvarusektorn (där värdeskapandet i princip följer det fysiska produktionsflödet), men däremot inte lika ofta i andra branscher, som saknar samma koppling mellan organisationens fysiska utformning och förädlingen. Bilden av organisationen är i exemplet kartor i råvarusektorn ikonisk ${ }^{29}$, det vill säga att bilden bygger på likhet med en materiell referenspunkt. De flesta affärsmodeller är dock inte lika tydligt kopplade till en fysisk terräng, vilket leder till ett antagande att dessa främst visar en konceptuellt grundad idé om organisationen. Detta väcker frågor om hur icke-ikoniska visuella diagram bidrar till att konstruera organisationen och dess "terräng", vad terrängen i sådana fall "består" av, och på vilka sätt diagram bidrar till en "karthet" i representationer. Ett exempel på en sådan diskussion presenterades i analysen av "indexikalitet" och "navigerbarhet" (Krämer, 2011) i Exempelruta $1 \mathrm{i}$ Kapitel 2. Där motsvarade diagrammet en "strategisk terräng", som även kopplades till ett antal mätbara nyckeltal genom länkning. Därigenom kom kartan att kopplas till en mätbar terräng och aktiviteter i verksamheten som dessa mätetal hörde till, trots sin o-kartlika visuella utformning. Frågor som denna motsvarar ett behov av fler exempel på hur redovisningsspråket knyter an till det visuella i exempelvis kartor men även diagram i allmänhet. Frågan är intressant med tanke på hur ofta kartan som idé förekommer som metafor för strategier och förändring i den företagsekonomiska diskursen, där begrepp som strategiska riktningar, kompasser och roadmaps är vanliga uttryck för navigationsmetaforen, som ofta kombineras med visualiseringar i olika former.

\footnotetext{
29 I den semiotiska litteraturen används "ikonisk" för att beteckna det av C. S. Peirces tre huvudkategorier av tecken (de övriga två är index och symboler) som bygger på likhet med det som avbildas (Sebeok, 2001) men begreppet kan också nyanseras till ett flertal varianter (Farias och Queiroz, 2006) och typer av likhet (t ex Ditlevsen, 2012b) och anses ha en kulturellt styrd tolkningsdimension (Sebeok, 2001).
} 


\section{Överlappningsperspektivet}

I takt med att visualisering ökar i betydelse i samhället och i redovisningen så är överlappningar mellan dessa "språk" viktiga att förstå. Redovisning har beskrivits som "the language of business" med fokus på en sifferbaserad, kvantifierande logik. Att då föreslå att tillföra visualitet, som ofta kopplas till estetik och andra former av vetande, kan ses som ett långt steg, och som jag visar i Kapitel 2 har detta "steg" tagit åtminstone tre olika riktningar. Jag beskriver i avhandlingen dessa steg som förklaringsmodeller för överlappning mellan visualitet och redovisning. Jag har inte hittat några andra exempel på att denna fråga problematiserats genom jämförelse på ett liknande sätt i tidigare litteratur. Snarare har diskussionen handlat om potentialen att inkorporera den visuella epistemologin i fler områden i organisations- och redovisningsstudier (t ex Gallhofer och Haslam, 1996; Davison och Warren, 2009; Bell och Davison, 2013; Meyer m.fl., 2013; Boxenbaum, Jones och Meyer, 2018) - som jag visar har dock alltså diskussionerna av visualitet utgått från olika förklaringsmodeller.

Avhandlingens slutsats avseende överlappningsperspektivet är att visa att visualiteten tar mer plats i redovisningssammanhang (Artikel II) och att den integreras mer med andra språk för redovisningen (Artikel IV och Artikel V). Med utgångspunkt i den minst utforskade av de tre förklaringsmodellerna som beskrevs i Kapitel 2, konvergensmodellen, diskuterar jag i det följande avsnittet överlappningar mellan visualitet och redovisning. Därmed utökas överlappningsperspektivet genom beskrivningar av visualitet och redovisning som två konvergerande delar. Det kan ses som en fördjupning av tidigare litteratur. Dessutom föreslår jag ett tillägg - alltså en förlängning av tidigare litteratur - till de tre förklaringsmodellerna, modellen "länkning". Jag diskuterar den nedan under rubriken "Länkning som fjärde förklaringsmodell".

\section{Konvergensmodeller för överlappning av visualitet och redovisning}

I Kapitel 2 diskuterade jag två varianter av överlappning som jag tolkade förekomma inom ramen för konvergensmodellen, rumslig och konceptuell konvergens. Rumslig konvergens avser rent platsmässig kombinering av material, även kallat multimodalitet i den semiotiska litteraturen (se t ex Meyer m.fl., 2013; Smith och O'Halloran, 2011). När det gäller denna variant visar avhandlingen att visualiteten tar större rumslig plats i redovisningssammanhang, och att den integreras mer med andra språk för redovisningen, vilket alltså är exempel på ökande rumslig konvergens mellan visualitet och andra sätt att uttrycka redovisning. I nyare årsredovisningar förkommer exempelvis fler kombinationer mellan visuella och andra format för att konstruera en mer visuellt grundad bild av organisationen. Ett exempel är att affärsmodellsdiagram kan spela en roll som självrepresentation (Artikel I) och att visuella format förekommer mer och i större grad integreras i årsredovisningen (Artikel II, IV). Med stöd av utvecklings- 
perspektivet visar jag att denna utveckling skett över tid och att det visuella tillför nya former när det gäller att konstruera bilden av organisationen.

De ovan beskrivna slutsatserna om ökande rumslig konvergens rör framförallt det jag i Kapitel 2 beskriver som undersökningsnivån artefakter (till skillnad från visualisering som process). Men hur är det med visualitet ur ett processperspektiv, som är minst lika relevant är det kommer till den praktiska tillverkningen och skapandet av informationen, det vill säga processperspektivet? Ester Appelgren (2007), som undersökte mediekonvergens i nyhetsbranschen, påpekar där att det finns flera aspekter som kan konvergera när det gäller tendensen att nyhetsmedier likriktas, såsom teknik och utrustning, marknader och tjänster, former för organisering av arbetet kring mediaproduktion och sättet som innehållet konsumeras - alltså olika aspekter som rör processen att skapa och använda artefakter. Som komplement till den rumsliga förståelsen av konvergens från Kapitel 2 så ger jag nedan, med stöd av Appelgrens lista, exempel på konvergenser utifrån processperspektivet, nämligen konvergens hos aktörer som framställer eller använder visuell redovisningsinformation.

Som Hopwood (1996) påpekar har marknadsföringsavdelningar kommit att bli viktigare aktörer när det gäller att ta fram årsredovisningen, som ibland beskrivs som ett dokument som både redogör för företagets tidigare prestationer och visar dess identitet (t ex Beattie m.fl., 2008; Ditlevsen, 2012a). I Artikel IV framkom det i mina intervjuer med framställare av årsredovisningen att aktörer som jobbade såväl externt på kommunikationsbyrå som internt på en kommunikationsavdelning (den "visuella sidan" av årsredovisningen) hade inflytande på utformningen av årsredovisningen, och därmed $i$ att förmedla den visuella bilden av organisationen via årsredovisningen. Det förekom dock samtidigt en uppdelning mellan den mer visuella "framvagnen" och den finansiellt grundade "bakvagnen" i själva årsredovisningsdokumentet i och med att dessa riktar sig till olika målgrupper. Dessutom innebar organisationsstrukturen en påverkan på framställandet av årsredovisningen eftersom olika enheter hade ansvar för sina egna avsnitt: controllers för det finansiella och kommunikatörer respektive extern kommunikationsbyrå för de narrativa och visuella delarna. Det förekom även samarbeten mellan olika enheter för att framställa helheten, och delarna sammanställdes i ett gemensamt dokument.

En annan form av konvergens förekommer på användarsidan avseende hur användarna tillgodoser sitt informationsbehov via visualisering, samt vilka tekniker som stöttar denna process. Till skillnad från aktörsperspektivet med fokus på tillverkarens arbetssätt som beskrivs ovan sker konvergensen här först när innehållet konsumeras av användaren. Som Appelgren (2007) noterar kan detta bygga på att användarna kombinerar och blandar olika medier när de konsumerar innehåll, genom att använda flera källor samtidigt eller växlar mellan dem. Ett perspektiv på detta kan illustreras med visualiseringstavlorna som beskrivs i Artikel $\mathrm{V}$, som kombinerade innehåll från olika källor i användnings- 
situationen och därmed kan ses som en teknik för konvergens ur användarperspektivet. Artikel V visar även att användarna i och med tavlorna kunde växla mellan flera olika format och typer av information för att "se" verksamheten, med följden att det totala intrycket byggde både på visualitet och på (visualiserade) siffror stöttat av en (analog eller digital) teknik.

Tavelanvändarna hade inga uppenbara problem med att växla mellan olika informationsformat på tavlan. Detta talar emot att visualitet och redovisning utgör starkt åtskilda språk, och att användarna - förutsatt att de har visuell och digital läskunnighet - bidrar till hur språken konvergerar i ekonomistyrningen. Här ser vi ett exempel på hur flerspråkighetsmodellen från överlappningsramverket även den kan tolkas som en modell för konvergens om den tillämpas på användarsidan av visualiseringsprocessen. Ur användarens perspektiv kan "flerspråkighet" kunna innebära antingen förmågan att förstå olika typer av format och användningen av dem - det som brukar avses med läskunnighet, exempelvis visuell, finansiell eller digital läskunnighet - eller - med stöd av konvergensperspektivet - förmågan att kombinera olika läskunnigheter i användningssituationen. Beskrivningar av visualiseringstavlornas roll som verktyg för konvergens kan därmed ses som ett bidrag till ekonomistyrningslitteraturen, som med få undantag (t ex Paring, Pezé och Huault, 2017), undersökt denna typ av artefakt och dess roller i organisationers styrning.

Medan ovanstående exempel utifrån förklaringsmodellen separation skulle kunna tolkas som att det visuella gör anspråk på redovisningens kärna så skulle analyser utifrån ett konvergensperspektiv kanske snarare intressera sig för formerna för konvergens och hur detta påverkar redovisningen. Speciellt intressant blir frågan om hur olika roller involverade i att konstruera bilden av organisationen förhåller sig till den visuella grammatikens möjligheter. Fortsatta studier med utgångspunkt i teknik-, innehålls- och aktörskonvergens skulle därför kunna utforska visualitet i redovisning genom att undersöka möten mellan aktörer från visualiseringssidan och redovisningssidan och hur respektive sida påverkar, omformulerar och omstrukturerar redovisningen i visuella termer.

\section{Länkning som fjärde förklaringsmodell för överlappning}

Det andra bidraget avseende förståelsen av visualitet ur överlappningsperspektivet är att en fjärde förklaringsmodell för överlappningar mellan visualitet och redovisning föreslås, som kan benämnas "länkning". Jag föreslår att länkningsmodellen kan kopplas till konceptet boundary objects ${ }^{30}$, som går ut på

\footnotetext{
30 Boundary object är ett teoribegrepp för att beskriva informationsobjekt såsom kartor och anteckningar (Star och Griesemer, 1989) eller managementprinciper såsom kaizen, standardisering och just-in-time eller IT-system (Briers och Chua, 2001), vilka sträcker sig över flera praktik- eller kunskapsdomäner. Begreppet användes först för att beskriva hur vetenskaplig kunskap (i Star och Griesemers fall naturhistoria) kan flyttas (översättas) mellan olika kunskapsdomäner, "sociala världar" om informationen
} 
att länka ihop separata domänområden med hjälp av artefakter och förklaringar. Ett exempel på länkning är den strategiberättelse som beskrivs $i$ fallet $i$ Exempelruta $1 \mathrm{i}$ Kapitel 2. Berättelsen användes vid införandet av en ny strategikarta då den visuella bilden inte var så lätt att förstå, vilket löstes genom att berätta om kopplingar till strategin samt genom att skapa extra illustrationer av vilka olika mätetal som kunde kopplas till de i kartan visualiserade områdena. Med andra ord länkades två separata områden ihop, inte genom konvergens eller integrering eftersom respektive språk behölls som de var och länkades sedan samman.

Även Artikel III innehåller exempel på länkningar. Personer i olika roller på startup-företaget hade olika uppfattningar om affärsmodellen, och den beskrevs på olika sätt internt och externt utifrån samma arketyp. Trots att olika bilder av organisationen konstruerades genom affärsmodellsbegreppet så förekom ingen uppenbar konflikt mellan dessa i praktiken, utan de kunde samexistera på olika nivåer och användas utifrån behov. Länkning kan utifrån dessa exempel ses som samtidig förekomst av olika bilder utifrån samma grundmodell, eller som sammankoppling av olika domäner utan att förändra respektive språk. I kontrast till separationsperspektivet föreslår jag att idén här inte går ut på att separera eller omformulera det visuella, utan snarare att flera domäner kan existera parallellt med länkningar mellan dem.

Tillägget av länkning som förklaringsmodell är intressant eftersom det antyder ett icke-integrerande sätt att kombinera redovisning med visualitet, och att dessa språk alltså inte konvergerar - det finns något redovisningsmässigt och något visuellt. Det är därför värt att fortsätta undersöka överlappningar utifrån länkningsmodellen, exempelvis med stöd av litteraturen om boundary objects, för att se om dessa kan observeras på fler områden avseende visualitet (eller andra format) i redovisningssammanhang. Sådana observationer skulle också kunna innebära en ökad förståelse av områden där visualisering och redovisning inte konvergerar eller integreras. Här vore även litteraturen om kommensurationens ("commensuration") sociologi (Espeland och Stevens, 1998, 2008) tillämparbar för att analysera vilka aspekter och visuella bilder som formuleras i kvantifierbara termer (kommensurabla) och vilka som "motstår" (Davison och Warren, 2009) detta (icke-kommensurabla). Jag föreslår att en sådan analys kan bidra till att med utgångspunkt $\mathrm{i}$ de olika förklaringsmodellerna vidareutveckla överlappningsperspektivet på visualitet i redovisningen.

får hjälp att bibehålla "koherens" över domängränserna, detta är syftet med ett boundary object. Med andra ord är ett boundary object något som binder samman - länkar - domäner. Detta möjliggör kommunikation över domängränser med stöd av objekt eller en idé som personer med olika bakgrund och förståelse kan samlas kring. Ett exempel hämtat från affärsmodellslitteraturen beskrivs av Doganova och Eyquem-Renault (2009), som visar hur ett franskt startupföretags affärsmodell formulerades i olika termer för olika målgrupper ( $\mathrm{ex}$ en visuell och en mer sifferbaserad beskrivning), som band samman intressenterna genom anpassade versioner av samma affärsmodell som rörde sig över aktörsgränserna. 


\section{Praktiska bidrag}

I detta avsnitt diskuterar jag avhandlingens praktiska bidrag. De delas in i två avsnitt, dels ramverk som kan tillämpas vid skapande, användning och granskning av visuella bilder för ökad visuell läskunnighet, dels metodbidrag till fortsatta utforskningar av visualitet i redovisningen.

\section{Ramverk för visuell läskunnighet}

Utvecklingsperspektivet visar att nya format och medier (t ex diagram) löpande börjar användas i redovisningssammanhang. Detta medför nya möjligheter att konstruera den visuella bilden av organisationen - och ett behov att kunna förstå, tolka och använda dessa. I och med visualitetens ökande förekomst och delvis förändrade roller föreslår jag därför att visuell läskunnighet kan vara ett sätt för praktiker att hantera denna utveckling. Avhandlingen bidrar med två ramverk som utvecklar förståelsen av visuella format, affärsmodellstypologin och rytmanalyser, vilka jag beskriver nedan.

Affärsmodellstypologin introducerar begreppet transformationalitet, som används i Artikel I för olika grader av värdeskapande i affärsmodellsdiagram. Detta sammanställs i en typologi med olika sätt att använda visualisering för att representera företagets approach till värdeskapande. I typologin diskuterar jag för- och nackdelar för varje typ av affärsmodellsvisualisering, och föreslår att valet av visualisering påverkar hur affärsmodellen, och därmed företaget, uppfattas när den beskrivs utifrån en viss visuell logik. Det blir därmed viktigt att välja "rätt" bild beroende på önskat budskap, vilket skapare och granskare av bilder bör ta med i beräkningen, exempelvis för att jämföra hur valet av diagramlogik matchar det tänkta budskapet vid användning av en affärsmodellsvisualisering. Det vore även möjligt att utgå från de visuella logikerna i typologin som underlag för diskussion av olika sätt att utforma affärsmodellen. Det andra ramverket om visuella rytmer bygger på en idé om att försöka förstå det visuellas förmåga att skapa mening genom att kombinera visuella format på olika sätt. Genom att tänka på bildanvändning som en sekvens med hjälp av metaforen rytm lyfts möjligheterna att konstruera budskap med olika kombinationer av bild och text. Ett exempel är att en gruppering av grafer föreslås kunna förstärka en finansiell logik medan ensamma stora grafer kan användas för att lyfta fram specifika budskap kopplat till texten; här kan rytm fungera som ett språk för att designa och utvärdera sådana kombinationer.

Ramverken visar hur bilder kan förstås i praktiken. Dock problematiserar Lowe m.fl. (2016) idén om en enda praktik genom att påpeka att "praktiker" inte avser en homogen grupp. I fallet med praktisk redovisning innefattas exempelvis "workers and managers, risk managers and traders, shop floor and CEO" (s. 312), som alla använder information men behöver förhålla sig till det visuella på olika sätt. Med anledning av detta resonemang delar jag i Tabell 4 in ovanstående 
förslag utifrån tre funktioner för bildanvändning (som även användes i min licentiatavhandling): att skapa, använda respektive granska visuella bilder.

Tabell 4. Ramverk för visuell läskunnighet utifrån funktionerna att skapa, använda respektive granska visuella bilder

\begin{tabular}{|c|c|c|c|}
\hline Ramverk & Skapa & Använda & Granska \\
\hline $\begin{array}{l}\text { Affärsmodells- } \\
\text { typologin } \\
\text { Exempel på olika } \\
\text { logiker för hur } \\
\text { värdeskapande } \\
\text { visualiseras i } \\
\text { diagram }\end{array}$ & $\begin{array}{l}\text { Inspiration till att } \\
\text { visualisera den egna } \\
\text { affärsmodellen } \\
\text { Nya sätt att se på } \\
\text { organisationen; } \\
\text { Jämföra avsett } \\
\text { budskap med } \\
\text { diagrammets logik }\end{array}$ & $\begin{array}{l}\text { Analysera hur } \\
\text { företag skapar } \\
\text { värde genom att } \\
\text { rita upp } \\
\text { affärsmodellen }\end{array}$ & $\begin{array}{l}\text { Identifiera } \\
\text { underliggande logiker } \\
\text { i diagram och } \\
\text { utvärdera deras } \\
\text { kommunikativa } \\
\text { funktioner }\end{array}$ \\
\hline $\begin{array}{l}\text { Visuella rytmer } \\
\text { Notationsmetod för } \\
\text { att undersöka } \\
\text { sekvenser och } \\
\text { kombinationer i } \\
\text { visuella material }\end{array}$ & $\begin{array}{l}\text { Skapa effektfull } \\
\text { kommunikation med } \\
\text { stöd av } \\
\text { rytmterminologi för att } \\
\text { se sekvenser }\end{array}$ & $\begin{array}{l}\text { Metod för att } \\
\text { undersöka } \\
\text { kombinationer } \\
\text { av visuella bilder } \\
\text { i texter }\end{array}$ & $\begin{array}{l}\text { Utvärdera hur grafer } \\
\text { kombineras och hur } \\
\text { detta påverkar } \\
\text { budskapet }\end{array}$ \\
\hline
\end{tabular}

Förslaget är att praktiker och forskare tillämpar metoderna som stöd för att förstå, undersöka och granska visualitet på nya sätt jämfört med tidigare, samt för att skapa visuella bilder att använda i redovisningssammanhang, exempelvis för att utveckla bilden av företaget med hjälp av affärsmodellsdiagram.

\section{Tillämpning och utveckling av visuella metoder som metodbidrag}

Ett återkommande tema i litteraturen om visualitet är att det visuella innebär ett nytt sätt att se organisationer (Bell och Davison, 2013) och att det är viktigt att plocka in fler visuella perspektiv (Boxenbaum, Jones och Meyer, 2018) eftersom det kan öka vår förståelse av premisserna för hur organisationer konstrueras som diskursiva objekt med stöd av redovisning, och därmed får kraft att påverka samhällsutvecklingen. En utmaning med nya områden är dock vilka metoder som ska användas för att utforska dem. Meyer m.fl. (2013) lyfter på detta spår fram behovet av att förstå hur det visuella fungerar som resurs och dess relationer till andra språk. De föreslår att tidigare förklaringar, såsom Barthes beskrivning av två sätt (anchorage och relay) att länka bild och text, är föråldrade och att nya metoder därför behövs. I dagsläget finns det med andra ord ett behov av att utveckla och tillämpa fler metoder och infallsvinklar på det visuella som möjliggör förståelse av visualitet.

Avhandlingen som helhet utgör ett metodbidrag i linje med detta behov då jag använder och vidareutvecklar visuella metoder som kan tillämpas praktiskt som analytiska eller praktiska metoder (se Kapitel 2) i den fortsatta utforskningen 
av visualitet i redovisning och management. Jag utför exempelvis visuell analys för att undersöka mönster i affärsmodeller (Artikel I) med stöd av semiotiska teorier. Vidare kan metoderna jag tar upp i avhandlingens metodkapitel, visuell juxtaposering och visuell innehållsanalys, även i fortsättningen användas för att belysa likheter och skillnader mellan visuella bilder, och deras retoriska och diskursiva funktioner. Dessutom utvecklar jag genom rytmramverket i Artikel IV en ny visuell metod, som bidrar till att nya sätt att undersöka visualitet i finansiell rapportering. Det föreslås i artikeln att ramverket kan användas för att undersöka, och nyansera förståelsen av, grafer och andra typer av visuella format $\mathrm{i}$ årsredovisningar. Jag öppnar därmed, i enlighet med den tolkande ansatsen, upp fler sätt att förstå grafer och andra visualiseringar i redovisningen.

Genom att visa hur metoderna kan användas, och vilka resultat de kan leda till, bidrar jag till behovet av fler visuella metoder, och jag hoppas att jag i och med detta visat potentialen i att fortsätta utforska de visuella dimensionerna i redovisningen, i organisationer och i samhället i stort. 


\section{KÄLLFÖRTECKNING}

Agrawala, M., Li, W. och Berthouzoz, F. (2011) "Design Principles for Visual Communication", Communications of the ACM, 54(4), s. 60-69.

Albinsson, A. (2016) "De va svinhögt typ 250 kilo": Förskolebarns mätande av längd, volym och tid i legoleken, Licentiatavhandling. Linköping Studies in Pedagogic Practices nr 27. Linköpings universitet, Linköping.

Alvesson, M. (2011) Interpreting Interviews. London: Sage.

Alvesson, M. och Willmott, H. (red.) (1992) "Introduction", i Critical Management Studies. London: Sage.

Amernic, J. och Craig, R. (2009) "Understanding accounting through conceptual metaphor: ACCOUNTING IS AN INSTRUMENT?", Critical Perspectives on Accounting, 20(8), s. 875-883.

Anderson, C. J. och Imperia, G. (1992) "The Corporate Annual Report: A Photo Analysis of Male and Female Portrayals", The Journal of Business Communication, 29(2), s. 113-129.

Andrew, J. (2011) "Accounting and the construction of the 'cost effective' prison", Journal of Australian Political Economy, s. 194-212.

Appelgren, E. (2007) Media Convergence and Digital News Services - adding value for producers and consumers. Doktorsavhandling. Medieteknik och grafisk produktion, Kungliga tekniska högskolan.

Arjaliès, D.-L. och Bansal, P. (2018) "Beyond numbers: How investment managers accommodate societal issues in financial decisions", Organization Studies, 39(5-6), s. 691-719.

Arksey, H. och Knight, P. (1999) Interviewing for Social Scientists. London: Sage.

Bačić, D. och Fadlalla, A. (2016) "Business information visualization intellectual contributions: An integrative framework of visualization capabilities and dimensions of visual intelligence", Decision Support Systems, 89, s. 77-86.

Baden-Fuller, C. och Morgan, M. S. (2010) "Business Models as Models", Long Range Planning, 43(2-3), s. 156-171.

Ballantyne, A. G. (2018) Exploring the Role of Visualization in Climate Change Communication: an Audience Perspective. Doktorsavhandling. Linköping Studies in Arts and Sciences nr. 744. Linköpings universitet.

Barthes, R. (1957/2009) Mythologies. London: Vintage.

Barthes, R. (1964/1977) "Rhetoric of the Image", i Image Music Text. London: Fontana Press, s. 32-51.

Barthes, R. (1968/1977) "The Death of the Author", i Image Music Text. London: Fontana Press, s. 142-148.

Barthes, R. (1970/1977) "The Third Meaning", i Image Music Text. London: Fontana Press, s. 52-68.

Barthes, R. (1980/2010) Camera Lucida: Reflections on Photography. Översatt av R. Howard. New York: Hill and Wang. 
Bateman, N., Philp, L. och Warrender, H. (2016) "Visual management and shop floor teams: development, implementation and use", International Journal of Production Research, 54(24), s. 7345-7358.

Baudrillard, J. (1981) Simulacra and Simulation. Översatt av S. F. Glaser. Ann Arbor: University of Michigan Press.

Beattie, V. A. (2014) "Accounting narratives and the narrative turn in accounting research: Issues, theory, methodology, methods and a research framework", The British Accounting Review, 46(2), s. 111-134.

Beattie, V. A., Dhanani, A. och Jones, M. J. (2008) "Investigating Presentational Change in U.K. Annual Reports: A Longitudinal Perspective", Journal of Business Communication, 45(2), s. 181-222.

Beattie, V. A. och Jones, M. J. (1997) "A Comparative Study of the Use of Financial Graphs in the Corporate Annual Reports of Major U.S. and U.K. Companies", Journal of International Financial Management \& Accounting, 8(1), s. 33-68.

Bell, E. och Davison, J. (2013) "Visual Management Studies: Empirical and Theoretical Approaches", International Journal of Management Reviews, 15(2), s. $167-184$.

Berger, J., m.fl. (1972) Ways of Seeing. London: Penguin Books.

Berger, P. L. och Luckmann, T. (1966) The Social Construction of Reality: A Treatise in the Sociology of Knowledge. London: Penguin Books.

Bergström, G. och Boréus, K. (2018) "Samhällsvetenskaplig text- och diskursanalys", i Textens mening och makt: Metodbok i samhällsvetenskaplig text- och diskursanalys. 4:e uppl. Lund: Studentlitteratur, s. 17-45.

Beynon-Davies, P. och Lederman, R. (2017) "Making sense of visual management through affordance theory", Production Planning \& Control, 28(2), s. 142-157.

Bini, L., Dainelli, F. och Giunta, F. (2016) "Business model disclosure in the Strategic Report: Entangling intellectual capital in value creation process", Journal of Intellectual Capital, 17(1), s. 83-102.

Blackwell, A. F. och Engelhardt, Y. (2002) "A Meta-Taxonomy for Diagram Research", i Olivier, P., Anderson, M., och Meyer, B. (red.) Diagrammatic Representation and Reasoning. London: Springer.

Boréus, K. och Kohl, S. (2018) "Innehållsanalys", i Boréus, K. och Bergström, G. (red.) Textens mening och makt: Metodbok i samhällsvetenskaplig text- och diskursanalys. 4:e uppl. Lund: Studentlitteratur, s. 49-89.

Bornemark, J. (2018) Det omätbaras renässans: En uppgörelse med pedanternas världsherravälde. Stockholm: Volante.

Boxenbaum, E., Jones, C. och Meyer, R. E. (2018) "Towards an articulation of the material and visual turn in organization studies", Organization Studies, 39(56), s. 597-616.

Breitbarth, T., Harris, P. och Insch, A. (2010) "Pictures at an exhibition revisited: reflections on a typology of images used in the construction of corporate social responsibility and sustainability in non-financial corporate reporting", Journal of Public Affairs, 10(4), s. 238-257.

Brennan, N. M., Guillamon-Saorin, E. och Pierce, A. (2009) "Impression management: Developing and illustrating a scheme of a methodological note", Accounting, Auditing \& Accountability Journal, 22(5), s. 789-832. 
Briers, M. och Chua, W. F. (2001) "The role of actor-networks and boundary objects in management accounting change: a field study of an implementation of activity based costing", Accounting, 26(3), s. 237-269.

Brown, J. (2010) "Accounting and visual cultural studies: potentialities, challenges and prospects", Accounting, Auditing \& Accountability Journal, 23(4), s. 482-505.

Burchell, S. m.fl. (1980) "The Roles of Accounting in Organizations and Society", Accounting, Organizations and Society, 5(1), s. 5-21.

Burgess, D. O. m.fl. (2008) "Does Graph Design Matter To CPAs And Financial Statement Readers?", Journal of Business \& Economics Research, 6(5), s. 111-124.

Börjesson, M. och Palmblad, E. (2007) Diskursanalys i praktiken. Malmö: Liber.

Campbell, D., McPhail, K. och Slack, R. (2009) "Face work in annual reports: A study of the management of encounter through annual reports, informed by Levinas and Bauman", Accounting, Auditing \& Accountability Journal, 22(6), s. 907-932.

Card, S. K., Mackinlay, J. D. och Shneiderman, B. (1999) Readings in Information Visualization: Using Vision to Think. San Francisco: Morgan Kaufmann Publishers.

Cardinaels, E. (2008) "The interplay between cost accounting knowledge and presentation formats in cost-based decision-making", Accounting, Organizations and Society, 33(6), s. 582-602.

Cheng, M. M. och Humphreys, K. A. (2012) "The Differential Improvement Effects of the Strategy Map and Scorecard Perspectives on Managers' Strategic Judgments", The Accounting Review, 87(3), s. 899-924.

Chia, R. (2005) "Organization Theory as a Postmodern Science", i Knudsen och Tsoukas (red.) The Oxford Handbook of Organization Theory. Oxford: Oxford University Press, s. 113-140.

Chiapello, E. och Baker, C. R. (2011) "The introduction of French theory into English language accounting research", Accounting, Auditing \& Accountability Journal, 24(2), s. 140-160.

Cooper, C. (2013) "A critical perspective", i Jack, L., Davison, J., och Craig, R. (red.) The Routledge Companion to Accounting Communication. London \& New York: Routledge, s. 242-253.

Cooper, D. J. och Sherer, M. J. (1984) "The value of the corporate accounting reports: Arguments for a political economy of accounting", Accounting, Organizations and Society, 9(3), s. 207-232.

Courtis, J. K. (1997) "Corporate Annual Report Graphical Communication in Hong Kong: Effective or Misleading?", Journal of Business Communication, 34(3), s. 269-288.

Culler, J. (1983) Barthes. London: Fontana.

Davison, J. (2008) "Rhetoric, repetition, reporting and the "dot.com" era: words, pictures, intangibles", Accounting, Auditing \& Accountability Journal, 21(6), s. 791-826.

Davison, J. (2010) "[In]visible [in]tangibles: Visual portraits of the business élite", Accounting, Organizations and Society, 35(2), s. 165-183.

Davison, J. (2011) "Barthesian perspectives on accounting communication and visual images of professional accountancy", Accounting, Auditing \& Accountability Journal, 24(2), s. 250-283. 
Davison, J. (2013) "Visual perspectives", i Jack, L., Davison, J., och Craig, R. (red.) The Routledge Companion to Accounting Communication. London \& New York: Routledge, s. 58-75.

Davison, J. (2014) "Visual rhetoric and the case of intellectual capital", Accounting, Organizations and Society, 39(1), s. 20-37.

Davison, J. (2015) "Visualising accounting: an interdisciplinary review and synthesis", Accounting and Business Research, 45(2), s. 121-165.

Davison, J., McLean, C. och Warren, S. (2012) "Exploring the visual in organizations and management", Qualitative Research in Organizations and Management: An International Journal, 7(1), s. 5-15.

Davison, J. och Warren, S. (2009) "Imag[in]ing accounting and accountability", Accounting, Auditing \& Accountability Journal, 22(6), s. 845-857.

Deegan, C. och Unerman, J. (2005) Financial Accounting Theory. Maidenhead: McGraw Hill.

Dickson, G. W., DeSanctis, G. och McBride, D. J. (1986) "Understanding The Effectiveness of Computer Graphics for Decision Support: A Cumulative Experimental Approach", Communications of the ACM, 29(1), s. 40-47.

Ditlevsen, M. G. (2012a) "Revealing corporate identities in annual reports", Corporate Communications: An International Journal, 17(3), s. 379-403.

Ditlevsen, M. G. (2012b) "Telling the Story of Danisco's Annual Reports (1935 Through 2007-2008) From a Communicative Perspective", Journal of Business and Technical Communication, 26(1), s. 92-115.

Doganova, L. och Eyquem-Renault, M. (2009) "What do business models do? Innovation devices in technology entrepreneurship", Research Policy, 38(10), s. $1559-1570$.

Doumont, J.-L. (2002) "Verbal Versus Visual: A Word Is Worth a Thousand Pictures, Too", Technical Communication, 49(2), s. 219-224.

Dragga, S. och Voss, D. (2001) "Cruel Pies: The Inhumanity of Technical Illustrations", Technical Communication, 48(3), s. 265-274.

Duff, A. (2011) "Big four accounting firms' annual reviews: A photo analysis of gender and race portrayals", Critical Perspectives on Accounting, 22(1), s. 20-38.

Ehrnberger, K. (2017) Tillblivelser: En trasslig berättelse om design som normkritisk praktik. Doktorsavhandling. Institutionen för maskinkonstruktion, Kungliga tekniska högskolan.

Emmison, M. (2016) "Visual Inquiry: Issues and Developments", i Silverman, D. (red.) Qualitative Methods. 4:e uppl. Thousand Oaks: Sage, s. 297-310.

Eppler, M. J. (2006) "A comparison between concept maps, mind maps, conceptual diagrams, and visual metaphors as complementary tools for knowledge construction and sharing", Information Visualization, 5(3), s. 202-210.

Eppler, M. J. och Platts, K. W. (2009) "Visual Strategizing: The Systematic Use of Visualization in the Strategic-Planning Process", Long Range Planning, 42(1), S. $42-74$.

Eriksson, E. (2017) Patterns of corporate visual self-representation in accounting narratives. Licentiatavhandling. Linköping Studies in Science and Technology nr 1792. Linköpings universitet, Linköping.

Espeland, W. N. och Stevens, M. L. (1998) "Commensuration as a Social Process", Annual Review of Sociology, 24, s. 313-353. 
Espeland, W. N. och Stevens, M. L. (2008) "A Sociology of Quantification", European Journal of Sociology, 49(3), s. 401-436.

Falk, T. m.fl. (2016) "Att beskriva organisationers strategi som en karta", i Nilsson, F., Petri, C.-J., och Westelius, A. (red.) Strategisk ekonomistyrning: med dialog $i$ fokus. Lund: Studentlitteratur.

Falschlunger, L. M. m.fl. (2015) "Impression management in annual reports of the largest European companies: A longitudinal study on graphical representations", Journal of Applied Accounting Research, 16(3), s. 383-399.

Farias, P. och Queiroz, J. (2006) "Images, diagrams, and metaphors: Hypoicons in the context of Peirce's sixty-six fold classification of signs", Semiotica, 1(4), s. 1-22.

Flyvbjerg, B. (2006) "Five Misunderstandings About Case-Study Research", Qualitative Inquiry, 12(2), s. 219-245.

Føllesdal, D., Walløe, L. och Elster, J. (2001) Argumentationsteori, språk och vetenskapsfilosofi. 3:e uppl. Översatt av M. Söderlind. Stockholm: Thales.

Fourcade, M. (2011) "Cents and Sensibility: Economic Valuation and the Nature of 'Nature'", American Journal of Sociology, 116(6), s. 1721-1777.

FRC (2014) "Guidance on the Strategic Report". London: Financial Reporting Council.

Gagliardi, P. (1996) "Exploring the Aesthetic Side of Organizational Life", i Clegg, Hardy och Nord (red.) Handbook of organization studies. Thousand Oaks: Sage, s. 565-580.

Gallhofer, S. och Haslam, J. (1996) "Accounting/art and the emancipatory project: some reflections", Accounting, Auditing \& Accountability Journal, 9(5), s. 23-44.

Gibson, J. J. (2015) The Ecological Approach to Visual Perception (Classic Edition). New York: Psychology Press.

Graham, C. (2013) "Teaching accounting as a language", Critical Perspectives on Accounting, 24(2), s. 120-126.

Graves, O. F., Flesher, D. L. och Jordan, R. E. (1996) "Pictures and the Bottom Line: The Television Epistemology of U.S. Annual Reports", Accounting, Organizations and Society, 21(1), s. 57-88.

Guillet de Monthoux, P. (2004) "Handlingens hermeneutik", i Gustavsson, B. (red.) Kunskapande metoder. 3:e uppl. Lund: Studentlitteratur, s. 95-114.

Guthey, E. och Jackson, B. (2005) "CEO Portraits and the Authenticity Paradox", Journal of Management Studies, 42(5), s. 1057-1082.

Hacking, I. (2005) Social konstruktion av vad? Översatt av B. Hansson. Stockholm: Thales.

Hanner, P. V. A. (1953) Årsredovisningen i praktiken. Stockholm: Företagsekonomiska Forskningsinstitutet vid Handelshögskolan i Stockholm.

Hauge, A. M. (2018) "Situated valuations: Affordances of management technologies in organizations", Scandinavian Journal of Management, 34(3), s. $245-255$.

Heiser, J. och Tversky, B. (2006) "Arrows in Comprehending and Producing Mechanical Diagrams", Cognitive Science, 30(3), s. 581-592.

Hellmann, A., Yeow, C. och De Mello, L. (2017) "The influence of textual presentation order and graphical presentation on the judgements of nonprofessional investors", Accounting and Business Research, 47(4), s. 455-470. 
Hines, R. D. (1988) "Financial Accounting: In Communicating Reality, We Construct Reality", Accounting, Organizations and Society, 13(3), s. 251-261. Hitchings, J. och Taylor, L. (2013) "A Big Four practitioner view", i Jack, L., Davison, J., och Craig, R. (red.) The Routledge Companion to Accounting Communication. London \& New York: Routledge, s. 213-227.

Hodge, R. och Kress, G. (1988) Social Semiotics. Ithaca: Cornell University Press. Hopwood, A. G. (1996) "Introduction", Accounting, Organizations and Society, 21(1), s. 55-56.

Hrasky, S. (2012) "Visual disclosure strategies adopted by more and less sustainability-driven companies", Accounting Forum, 36(3), s. 154-165.

Hultin, L. och Mähring, M. (2014) "Visualizing institutional logics in sociomaterial practices", Information and Organization, 24(3), s. 129-155.

Husin, N. M., Cooper, K. och Olesen, K. (2012) "Analysis of intellectual capital disclosure - an illustrative example", Journal of Intellectual Capital, 13(2), s. $196-220$.

ICAEW (2010) Business Models in Accounting: The Theory of the Firm and Financial Reporting. The Institute of Chartered Accountants in England and Wales. Tillgänglig vid: www.icaew.com/technical/financial-reporting.

Islam, S. (2018) "A practitioner's guide to the design of strategy map frameworks", Pacific Accounting Review, 30(3), s. 334-351.

Jaca, C. m.fl. (2014) "Do companies with greater deployment of participation systems use Visual Management more extensively? An exploratory study", International Journal of Production Research, 52(6), s. 1755-1770.

Janvrin, D. J., Raschke, R. L. och Dilla, W. N. (2014) "Making sense of complex data using interactive data visualization", Journal of Accounting Education, 32(4), s. 31-48.

Jack, L., Davison, J. och Craig, R. (red.) (2013) "The Power of Accounting Communication", i The Routledge Companion to Accounting Communication. London \& New York: Routledge, s. 3-6.

Justesen, L. och Mouritsen, J. (2009) "The triple visual: Translations between photographs, 3-D visualizations and calculations", Accounting, Auditing \& Accountability Journal, 22(6), s. 973-990.

Kamla, R. och Roberts, C. (2013) "The global and the local: Arabian Gulf States and imagery in annual reports", Accounting, Auditing \& Accountability Journal, 23(4), s. 449-481.

Kaplan, R. S. och Norton, D. P. (1992) "The Balanced Scorecard: Measures That Drive Performance", Harvard Business Review, 70(1), s. 71-79.

Kaplan, R. S. och Norton, D. P. (1996/2007) "Using the Balanced Scorecard as a Strategic Management System", Harvard Business Review, 85(7/8), s. 150161.

Kaplan, R. S. och Norton, D. P. (2000) "Having Trouble with Your Strategy? Then Map It", Harvard Business Review, 78(September-October), s. 167-176.

Kaplan, R. S. och Norton, D. P. (2004) "The strategy map: guide to aligning intangible assets", Strategy \& Leadership, 32(5), s. 10-17.

Kazmierczak, E. T. (2001) "A semiotic perspective on aesthetic preference, visual literacy, and information design", Information Design Journal, 10(2), s. 176187. 
Klein, H. K. och Myers, M. D. (1999) "A Set of Principles for Conducting and Evaluating Interpretive Field Studies in Information Systems", MIS Quarterly, 23(1), s. 67-93.

Krämer, S. (2011) "The Mind's Eye: Visualizing the Non-visual and the Epistemology of the Line", i Heinrich, R. m.fl. (red.) Image and Imaging in Philosophy and the Arts, Vol. 2. Frankfurt: Ontos Verlag, s. 275-293.

Kress, G. och van Leeuwen, T. (2006) Reading Images: The Grammar of Visual Design. 2:a uppl. London \& New York: Routledge.

Laidroo, L. och Tamme, N. (2016) "Graphs in Annual Reports of Banks: Trustworthy or Not?", i Bilgin, M. m.fl. (red.) Business Challenges in the Changing Economic Landscape. Cham: Springer International, s. 147-166.

Larkin, J. H. och Simon, H. A. (1987) "Why a Diagram is (Sometimes) Worth Ten Thousand Words", Cognitive Science, 11(1), s. 65-99.

Latour, B. (1987) Science in Action. Cambridge, Massachusetts: Harvard University Press.

Lavoie, D. (1987) "The Accounting of Interpretations and the Interpretations of Accounts: The Communicative Function of 'The Language of Business'", Accounting, Organizations and Society, 12(6), s. 579-604.

Ledin, P. och Machin, D. (2016) "The evolution of performance management discourse in corporate strategy diagrams for public institutions", Discourse, Context and Media, 13(B), s. 122-131.

van Leeuwen, T. (2005) Introducing Social Semiotics. London: Routledge.

Lima, M. (2011) Visual Complexity: Mapping Patterns of Information. New York: Princeton Architectural Press.

Lowe, A. D., De Loo, I. och Nama, Y. (2016) "Cutting the Gordian knot [?]: a response to Lukka and Vinnari (2014)", Accounting, Auditing \& Accountability Journal, 29(2), s. 305-316.

Lowe, D. J., Carmona-Moreno, S. och Reckers, P. M. J. (2011) "The influence of strategy map communications and individual differences on multidimensional performance evaluations", Accounting and Business Research, 41(4), s. 375391.

Lukka, K. och Vinnari, E. (2014) "Domain theory and method theory in management accounting research", Accounting, Auditing \& Accountability Journal, 27(8), s. 1308-1338.

Lukka, K. och Vinnari, E. (2016) "Domain theory and method theory revisited: a reply to Lowe, De Loo and Nama", Accounting, Auditing \& Accountability Journal, 29(2), s. 317-322.

Macintosh, N. B. m.fl. (2000) "Accounting as simulacrum and hyperreality: perspectives on income and capital", Accounting, Organizations and Society, 25, s. $13-50$.

Magretta, J. (2002) "Why Business Models Matter", Harvard Business Review, 80(5), s. 86-92.

Mather, P., Ramsay, A. och Serrey, A. (1996) "The Use and Representational Faithfulness of Graphs in Annual Report", Australian Accounting Review, 6(2), s. 56-63.

McKinstry, S. (1996) "Designing the annual reports of Burton plc from 1930 to 1994", Accounting, Organizations and Society, 21(1), s. 89-111. 
Meyer, R. E., Höllerer, M. A., Jancsary D. och van Leeuwen, T. (2013) "The Visual Dimension in Organizing, Organization, and Organization Research: Core Ideas, Current Developments, and Promising Avenues", Academy of Management Annals, 7(1), s. 489-555.

Miles, M. B., Huberman, A. M. och Saldaña, J. (2014) Qualitative Data Analysis: A Methods Sourcebook. 3:e uppl. Los Angeles: Sage.

Miller, P. och O'Leary, T. (1994) "Governing the calculable person", i Hopwood, A. G. och Miller, P. (red.) Accounting as social and institutional practice. Cambridge: Cambridge University Press, s. 98-115.

Morgan, G. (1999) Organisationsmetaforer]. Översatt av B. Nilsson. Lund: Studentlitteratur.

Möslein, K. M. (2000) Bilder in Organisationen: Wandel, Wissen und Visualiserung. Wiesbaden: Gabler-DUV.

Nilsson, F. och Stockenstrand, A.-K. (2015) Financial Accounting and Management Control: The Tensions and Conflicts Between Uniformity and Uniqueness. Heidelberg: Springer.

Overud, J. (2019) "Memory-Making in Kiruna - Representations of Colonial Pioneerism in the Transformation of a Scandinavian Mining Town", Culture Unbound, 11(1), s. 104-123.

Paring, G., Pezé, S. och Huault, I. (2017) "Welcome to the whiteboard, the new member of the team': Identity regulation as a sociomaterial process", Organization, 24(6), s. 844-865.

Petri, C.-J. och Olve, N.-G. (2014) Strategibaserad styrning: så använder du strategikartor och styrkort för att nå organisationens mål. Stockholm: Liber.

Preston, A. M., Wright, C. och Young, J. J. (1996) "Imag[in]ing Annual Reports", Accounting, Organizations and Society, 21(1), s. 113-137.

Prior, L. (2016) "Using Documents in Social Research", i Silverman, D. (red.) Qualitative Methods. 4:e uppl. Thousand Oaks: Sage, s. 171-185.

Purchase, H. C. (2014) "Twelve years of diagrams research", Journal of Visual Language and Computing, 25(2), s. 57-75.

Qu, S. Q. och Cooper, D. J. (2011) "The role of inscriptions in producing a balanced scorecard", Accounting, Organizations and Society, 36(6), s. 344-362.

Quattrone, P. (2009) "Books to be practiced: Memory, the power of the visual, and the success of accounting", Accounting, Organizations and Society, 34(1), s. $85-118$.

Quattrone, P. (2016) "Management accounting goes digital: Will the move make it wiser?", Management Accounting Research, 31, s. 118-122.

Radits, M. (2019) A Business Ecology Perspective on Community-Driven Open Source: The Case of the Free and Open Source Content Management System Joomla. Doktorsavhandling. Linköping Studies in Science and Technology, nr 1937 Linköpings universitet.

Ray, J. L. och Smith, A. D. (2012) "Using Photographs to Research Organizations: Evidence, Considerations, and Application in a Field Study", Organizational Research Methods, 15(2), s. 288-315.

Rose, G. (2001) Visual methodologies: An Introduction to the Interpretation of Visual Materials. Thousand Oaks: Sage. 
Scheja, M. (2009) Börsbolags redovisning av alternativa resultatbegrepp: En studie om hur, och varför, bolag noterade på Stockholmsbörsen redovisar NonGAAP Measures. Doktorsavhandling. Linköping Studies in Science and Technology nr. 1258. Linköpings universitet.

Scherer, A. G. (2009) "Critical Theory and its Contribution to Critical Management Studies", i Alvesson, M., Bridgman, T., och Willmott, H. (red.) The Oxford Handbook of Critical Management Studies. Oxford: Oxford University Press, s. 29-51.

Sebeok, T. A. (2001) Signs: An Introduction to Semiotics. 2:a uppl. Toronto: University of Toronto Press.

Shannon, C. E. och Weaver, W. (1949/1964) The Mathematical Theory of Communication. Champaign: The University of Illinois Press.

Shneiderman, B. och Lima, M. (2014) Book of Trees. Hudson: Princeton Architectural Press.

Sibbet, D. (2008) "Visual Intelligence: Using the Deep Patterns of Visual Language to Build Cognitive Skills", Theory Into Practice, 47(2), s. 118-127.

Smith, B. A. och O'Halloran, K. (red.) (2011) "Multimodal Studies", i Multimodal Semiotics: Functional Analysis in Contexts of Education. Routledge, s. 1-14.

So, S. och Smith, M. (2002) "Colour graphics and task complexity in multivariate decision making", Accounting, Auditing \& Accountability Journal, 15(4), s. 565-593.

Staffansson Pauli, K. (2016) "Representations of gender in annual reports in the real estate industry in Sweden", Property Management, 34(1), s. 5-17.

Star, S. L. och Griesemer, J. R. (1989) "Institutional Ecology, 'Translations' and Boundary Objects: Amateurs and Professionals in Berkeley's Museum of Vertebrate Zoology", Social Studies of Science, 19(3), s. 387-420.

Steinbart, P. J. (1989) "The Auditor's Responsibility for the Accuracy of Graphs in Annual Reports: Some Evidence of the Need for Additional Guidance", Accounting Horizons, 3(3), s. 60-70.

Strong, D. M. m.fl. (2014) "A Theory of Organization-EHR Affordance", Journal of the Association for Information Systems, 15(2), s. 53-85.

Sundström, A. (2015) Representing Performance | Performing Representation: Ontology in accounting practice. Doktorsavhandling. Stockholms universitet.

Suwa, M. och Tversky, B. (1997) "What do architects and students perceive in their design sketches? A protocol analysis", Design Studies, 18(4), s. 385-403.

Suzuki, T. (2003) "The accounting figuration of business statistics as a foundation for the spread of economic ideas", Accounting, Organizations and Society, 28(1), s. 65-95.

Taipaleenmäki, J. och Ikäheimo, S. (2013) "On the convergence of management accounting and financial accounting - the role of information technology in accounting change", International Journal of Accounting Information Systems, 14(4), s. 321-348.

Täuscher, K. och Abdelkafi, N. (2017) "Visual tools for business model innovation: Recommendations from a cognitive perspective", Creativity and Innovation Management, 26(2), s. 160-174.

Tebeaux, E. (2000) "Visual texts: Format and the Evolution of English Accounting Texts 1100-1700", Journal of Technical Writing and Communication, 30(4), s. 307-341. 
Teece, D. J. (2010) "Business Models, Business Strategy and Innovation", Long Range Planning, 43(2-3), s. 172-194.

Toraldo, M. L., Islam, G. och Mangia, G. (2018) "Modes of Knowing: Video Research and the Problem of Elusive Knowledges", Organizational Research Method, 21(2), s. 438-465.

Tracy, S. J. och Redden, S. M. (2016) "Markers, Metaphors, and Meaning: Drawings as a Visual and Creative Qualitative Research Methodology in Organizations", i Kramer, R. M. och Elsbach K. D. (red.) Handbook of Qualitative Organizational Research. New York: Taylor and Francis, s. 238-248.

Tufte, E. R. (1990) Envisioning Information. Cheshire: Graphics Press.

Tversky, B. (1997) "Cognitive Principles of Graphic Displays", AAAl Technical Report FS-97-03, s. 116-124.

Tversky, B. (2011) "Visualizing Thought", Topics in Cognitive Science, 3(3), s. 499-535.

Valsiner, J. (2000) "Data as representations: contextualizing qualitative and quantitative research strategies", Social Science Information, 39(1), s. 99-113.

Warren, S. (2009) "Visual Methods in Organizational Research", i Buchanan, D. A. och Bryman, A. (red.) The Sage Handbook of Organizational Research Methods. London: Sage, s. 567-582.

Winther Jørgensen, M. W. och Phillips, L. (2000) Diskursanalys som teori och metod. Översatt av S.-E. Torhell. Lund: Studentlitteratur.

Womack, J. P. och Jones, D. T. (2003) Lean Thinking: Banish Waste and Create Wealth in Your Corporation. London: Simon \& Schuster.

Yates, J. och Orlikowski, W. J. (1992) "Genres of Organizational Communication: A Structurational Approach to Studying Communication and Media", Academy of Management Review, 17(2), s. 299-326.

Zammuto, R. F. m.fl. (2007) "Information Technology and the Changing Fabric of Organization", Organization Science, 18(5), s. 749-762. 


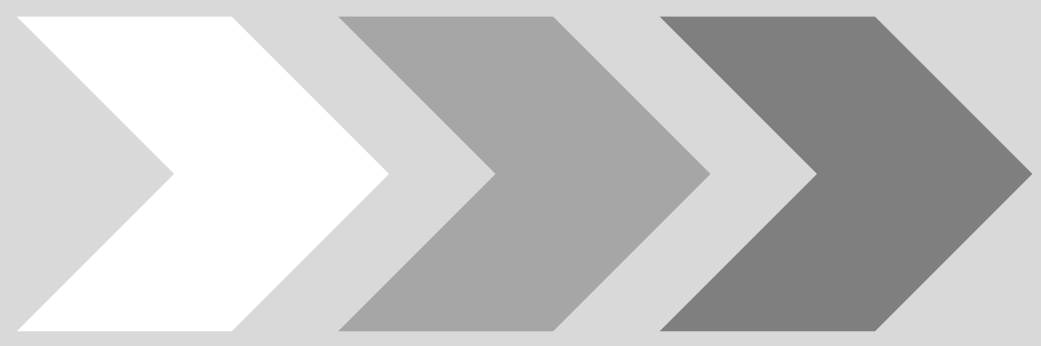

BILAGOR 



\section{Artiklar}

The papers associated with this thesis have been removed for copyright reasons. For more details about these see:

http://urn.kb.se/resolve?urn=urn:nbn:se:liu:diva-165208 



\section{THESES IN \\ ECONOMIC INFORMATION SYSTEMS}

\section{DOCTORAL THESES}

1. Savén, Bengt, 1995, Verksamhetsmodeller för beslutsstöd och lärande - En studie av produktionssimulering vid Asea/ABB 1968-1993. Doktorsavhandling 371, IDAEIS, Universitetet och Tekniska Högskolan i Linköping.

2. Villegas, Jaime, 1996, Simulation Supported Industrial Training from an Organizational Learning Perspective - Development and Evaluation of the SSIT Method. Doktorsavhandling 429, IDA-EIS, Universitetet och Tekniska Högskolan i Linköping.

3. Nilsson, Fredrik, 1997, Strategi och ekonomisk styrning - En studie av hur ekonomiska styrsystem utformas och används efter företagsförvärv. Doktorsavhandling 475, IDA-EIS, Universitetet och Tekniska Högskolan i Linköping.

4. Moberg, Anna, 1997, Närhet och distans - Studier av kommunikationsmönster $i$ satellitkontor och flexibla kontor. Doktorsavhandlaing 512, IDA-EIS, Universitetet och Tekniska Högskolan i Linköping.

5. Lindström, Jörgen, 1999, Does Distance Matter? On Geographical Dispersion in Organisations. Doktorsavhandling 567, IDA-EIS, Universitetet och Tekniska Högskolan i Linköping.

6. Tjäder, Jimmy, 2000, Systemimplementering $i$ praktiken - En studie av logiker $i$ fyra projekt. Doktorsavhandling 618, IDA-EIS, Universitetet och Tekniska Högskolan i Linköping.

7. Petri, Carl-Johan, 2001, Organizational Information Provision - Managing Mandatory and Discretionary Use of Information Technology. Doktorsavhandling 720, IDA-EIS, Universitetet och Tekniska Högskolan i Linköping.

8. Gäre, Klas, 2003, Tre perspektiv på förväntningar och förändringar $i$ samband med införande av informationssystem. Doktorsavhandling 808, IDA-EIS, Universitetet och Tekniska Högskolan i Linköping.

9. Skåmedal, Jo, 2004, Telecommuting's Implications on Travel and Travel Patterns. Doktorsavhandling 869, IDA-EIS, Universitetet och Tekniska Högskolan i Linköping.

10. Askenäs, Linda, 2004, The Roles of IT - Studies of Organising when Implementing and Using Enterprise Systems. Doktors-avhandling 870, IDA-EIS, Universitetet och Tekniska Högskolan i Linköping. 
11. Wang, Zhiping, 2004, Capacity-Constrained Production-Inventory Systems Modelling and Analysis in both a Traditional and an E-Business Context. Doktorsavhandling 889, IDA-EIS, Universitetet och Tekniska Högskolan i Linköping.

12. Kald, Magnus, 2004, In the Borderland between Strategy and Management Control - Theoretical Frameworks and Empirical Evidence. Doktorsavhandling 910, IDA-EIS, Universitetet och Tekniska Högskolan i Linköping.

13. Cäker, Mikael, 2005, Management Accounting as Constructing and Opposing Customer Focus - Three Case Studies on Management Accounting and Customer Relations. Doktorsavhandling 933, IDA-EIS, Universitetet och Tekniska Högskolan i Linköping.

14. Keller, Christina, 2007, Virtual Learning Environments in Higher Education - A Study of User Acceptance. Doktors-avhandling 1114, IEI-EIS, Universitetet och Tekniska Högskolan i Linköping.

15. Cöster, Mathias, 2007, The Digital Transformation of the Swedish Graphic Industry. Doktorsavhandling 1126, IEI-EIS, Universitetet och Tekniska Högskolan i Linköping.

16. Ahlström, Petter, 2008, Strategier och styrsystem för seniorboendemarknaden. Doktorsavhandling 1188, IEI-EIS, Universitetet och Tekniska Högskolan i Linköping.

17. Scheja, Mikael, 2009, Börsbolags redovisning av alternativa resultatbegrepp - En studie om hur, och varför, bolag noterade på Stockholmsbörsen redovisar 'NonGAAP measures'. Doktorsavhandling 1258, IEI-EIS, Universitetet och Tekniska Högskolan i Linköping.

18. Nilsson, Erik B., 2010, Strategi, styrning och konkurrenskraft - En longitudinell studie av Saab AB. Doktorsavhandling 1318, IEI-EIS, Universitetet och Tekniska Högskolan i Linköping.

19. Imre, Özgün, 2018, Adopting information systems - Perspectives from small organizations. Doktorsavhandling 1895, IEI-EIS, Universitetet och Tekniska Högskolan i Linköping.

20. Odar, Susanne, 2019, Managementinitiativ, mening och verksamhetsresultat - En retrospektiv studie av en teknikintensiv verksamhet. Doktorsavhandling 1970, IEIEIS, Universitetet och Tekniska Högskolan i Linköping.

21. Radits, Markus, 2019, A Business Ecology Perspective on Community-Driven Open Source: The Case of the Free and Open Source Content Management System Joomla. Doktorsavhandling 1937, IEI-EIS, Universitetet och Tekniska Högskolan i Linköping.

22. Havemo, Emelie, 2020. Den visuella bilden av organisationen: perspektiv på visualitet $i$ redovisningen. Doktorsavhandling 2075, IEI-EIS, Universitetet och Tekniska Högskolan i Linköping. 


\section{LICENTIATE THESES}

1. Larsson, Rolf, 1992, Aktivitetsbaserad kalkylering i ett nytt ekonomisystem. Licentiatavhandling 298, IDA-EIS, Universitetet och Tekniska Högskolan i Linköping.

2. Noghabai, Mehran, 1993, Värdering av strategiska datorinvesteringar-Med ett ledningsperspektiv på FMS- och KIS-investeringar. Licentiatavhandling 371, IDA-EIS, Universitetet och Tekniska Högskolan i Linköping.

3. Moberg, Anna, 1993, Satellitkontor - En studie av kommunikationsmönster vid arbete på distans. Licentiatavhandling 406, IDA-EIS, Universitetet och Tekniska Högskolan i Linköping.

4. Carlsson, Peter, 1994, Separation av företagsledning och finansiering Fallstudier av företagsledarutköp ur ett agentteoretiskt perspektiv. Licentiatavhandling 414, IDA-EIS, Universitetet och Tekniska Högskolan i Linköping.

5. Sjöström, Camilla, 1994, Revision och lagreglering - Ett historiskt perspektiv. Licentiatavhandling 417, IDA-EIS, Universitetet och Tekniska Högskolan i Linköping.

6. Poignant, Lars, 1994, Informationsteknologi och företagsetablering-Effekter på produktivitet och region. Licentiatavhandling 441, IDA-EIS, Universitetet och Tekniska Högskolan i Linköping.

7. Lind, Jonas, 1994, Creditor-Firm Relations: An Interdisciplinary Analysis. Licentiatavhandling 451, IDA-EIS, Universitetet och Tekniska Högskolan i Linköping.

8. Nilsson, Fredrik, 1994, Strategi och ekonomisk styrning - En studie av Sandviks förvärv av Bahco Verktyg. Licentiatavhandling 463, IDA-EIS, Universitetet och Tekniska Högskolan i Linköping.

9. Lagerström, Bo, 1995, Successiv resultatavräkning av pågående arbeten Fallstudier i tre byggföretag. Licentiatavhandling 476, IDA-EIS, Universitetet och Tekniska Högskolan i Linköping.

10. Andersson, Jörgen, 1995, Bilder av småföretagares ekonomistyrning. Licentiatavhandling 522, IDA-EIS, Universitetet och Tekniska Högskolan i Linköping.

11. Larsen, Kristina, 1996, Förutsättningar och begränsningar för arbete på distans - Erfarenheter från fyra svenska företag. Licentiatavhandling 550, IDA-EIS, Universitetet och Tekniska Högskolan i Linköping.

12. Lindström, Jörgen, 1996, Chefers användning av kommunikationsteknik. Licentiatavhandling 587, IDA-EIS, Universitetet och Tekniska Högskolan i Linköping.

13. Larsson, Annika, 1996, Ekonomisk styrning och organisatorisk passion - Ett interaktivt perspektiv. Licentiatavhandling 595, IDA-EIS, Universitetet och Tekniska Högskolan i Linköping. 
14. Ollinen, Jan, 1997, Det flexibla kontorets utveckling på Digital - Ett stöd för multiflex? Licentiatavhandling 623, IDA-EIS, Universitetet och Tekniska Högskolan i Linköping.

15. Zetterlund, Per-Ove, 1998, Normering av svensk redovisning - En studie av tillkomsten av Redovisningsrådets rekommendation om koncernredovisning, RR01:91. Licentiatavhandling 668, IDA-EIS, Universitetet och Tekniska Högskolan i Linköping.

16. Tjäder, Jimmy, 1998, Projektledaren \& planen - En studie av projektledning $i$ tre installations- och systemutvecklingsprojekt. Licentiatavhandling 675, IDAEIS, Universitetet och Tekniska Högskolan i Linköping.

17. Wennestam, Christina, 1998, Information om immateriella resurser Investeringar $i$ forskning och utveckling samt i personal inom skogsindustrin. Licentiatavhandling 712, IDA-EIS, Universitetet och Tekniska Högskolan i Linköping.

18. Westin, Carl-Johan, 1998, Informationsförsörjning: En fråga om ansvar Aktiviteter och uppdrag $i$ fem stora svenska organisationers operativa informationsförsörjning. Licentiatavhandling 730, IDA-EIS, Universitetet och Tekniska Högskolan i Linköping.

19. Jansson, Åse, 1998, Miljöhänsyn - En del i företags styrning. Licentiatavhandling 731, IDA-EIS, Universitetet och Tekniska Högskolan i Linköping.

20. Bäckström, Anders, 1998, Värdeskapande kreditgivning - Kreditriskhantering ur ett agentteoretiskt perspektiv. Licentiatavhandling 734, IDA-EIS, Universitetet och Tekniska Högskolan i Linköping.

21. Ferntoft, Anders, 1999, Elektronisk affärskommunikation - Kontaktkostnader och kontaktprocesser mellan kunder och leverantörer på producentmarknader. Licentiatavhandling 751, IDA-EIS, Universitetet och Tekniska Högskolan i Linköping.

22. Alvehus, Johan, 1999, Mötets metaforer - En studie av berättelser om möten. Licentiatavhandling 753, IDA-EIS, Universitetet och Tekniska Högskolan i Linköping.

23. Skåmedal, Jo, 1999, Arbete på distans och arbetsformens påverkan på resor och resemönster. Licentiatavhandling 752, IDA-EIS, Universitetet och Tekniska Högskolan i Linköping.

24. Gäre, Klas, 1999, Verksamhetsförändringar $i$ samband med IS-införande. Licentiatavhandling 791, IDA-EIS, Universitetet och Tekniska Högskolan i Linköping.

25. Björkegren, Charlotte, 1999, Learning for the Next Project - Bearers and Barriers in Knowledge Transfer within an Organisation. Licentiatavhandling 787, IDA-EIS, Universitetet och Tekniska Högskolan i Linköping.

26. Askenäs, Linda, 2000, Affärssystemet - En studie om teknikens aktiva och passiva roll $i$ en organisation. Licentiatavhandling 808, IDA-EIS, Universitetet och Tekniska Högskolan i Linköping. 
27. Nilsson, Håkan, 2000, Informationsteknik som drivkraft i granskningsprocessen - En studie av fyra revisionsbyråer. Licentiatavhandling 788, IDA-EIS, Universitetet och Tekniska Högskolan i Linköping.

28. Kald, Magnus, 2000, The Role of Management Control Systems in Strategic Business Units. Licentiatavhandling 842, IDA-EIS, Universitetet och Tekniska Högskolan i Linköping.

29. Cäker, Mikael, 2000, Vad kostar kunden? Modeller för intern redovisning. Licentiatavhandling 844, IDA-EIS, Universitetet och Tekniska Högskolan i Linköping.

30. Lindahl, Magnus, 2000, Bankens villkor i låneavtal vid kreditgivning till högt belånade företagsförvärv - En studie ur ett agentteoretiskt perspektiv. Licentiatavhandling 754, IDA-EIS, Universitetet och Tekniska Högskolan i Linköping.

31. Bergum, Svein, 2000, Managerial Communication in Telework. Licentiatavhandling 807, IDA-EIS, Universitetet och Tekniska Högskolan i Linköping.

32. Svarén, Stefan, 2001, Styrning av investeringar i divisionaliserade företag - Ett koncernperspektiv. Licentiatavhandling 894, IDA-EIS, Universitetet och Tekniska Högskolan i Linköping.

33. Sandell, Niklas, 2001, Redovisning i skuggan av en bankkris - Värdering av fastigheter. Licentiatavhandling 915, IDA-EIS, Universitetet och Tekniska Högskolan i Linköping.

34. Odar, Susanne, 2002, IT som stöd för strategiska beslut, en studie av datorimplementerade modeller av verksamhet som stöd för beslut om anskaffning av JAS 1982. Licentiatavhandling 916, IDA-EIS, Universitetet och Tekniska Högskolan i Linköping.

35. Hansson, Emma, 2001, Optionsprogram för anställda - En studie av svenska börsbolag. Licentiatavhandling 917, IDA-EIS, Universitetet och Tekniska Högskolan i Linköping.

36. Sevenius, Robert, 2002, On the Instruments of Governance - A Law \& Economics Study of Capital Instruments in Limited Liability Companies. Licentiatavhandling 956, IDA-EIS, Universitetet och Tekniska Högskolan i Linköping.

37. Berglund, Fredrika, 2002, Management Control and Strategy - A Case Study of Pharmaceutical Drug Development. Licentiatavhandling 958, IDA-EIS, Universitetet och Tekniska Högskolan i Linköping.

38. Nilsson, Peter, 2003, Svenska bankers redovisningsval vid reservering för befarade kreditförluster - En studie vid införande av nya redovisningsregler. Licentiatavhandling 1033, IDA-EIS, Universitetet och Tekniska Högskolan i Linköping.

39. Stoltz, Charlotte, 2004, Calling for Call Centres - A Study of Call Centre Locations in a Swedish Rural Region. Licentiatavhandling 1084, IDA-EIS, Universitetet och Tekniska Högskolan i Linköping. 
40. Sällberg, Henrik, 2004, On the Value of Customer Loyalty Programs - A Study of Point Programs and Switching Costs. Licentiatavhandling 1116, IDA-EIS, Universitetet och Tekniska Högskolan i Linköping.

41. Vascós Palacios, Fidel, 2005, On the Information Exchange between Physicians and Social Insurance Officers in the Sick Leave Process - An Activity Theoretical Perspective. Licentiatavhandling 1165, IDA-EIS, Universitetet och Tekniska Högskolan i Linköping.

42. Keller, Christina, 2005, Virtual Learning Environments in Higher Education - A Study of Students' Acceptance of Educational Technology. Licentiatavhandling 1167, IDA-EIS, Universitetet och Tekniska Högskolan i Linköping.

43. Ahlström, Petter, 2005, Affärsstrategier för seniorbostadsmarknaden. Licentiatavhandling 1172, IDA-EIS, Universitetet och Tekniska Högskolan i Linköping.

44. Cöster, Mathias, 2005, Beyond IT and Productivity - How Digitization Transformed the Graphic Industry. Licentiatavhandling 1183, IDA-EIS, Universitetet och Tekniska Högskolan i Linköping.

45. Horzella, Åsa, 2005, Beyond IT and Productivity - Effects of Digitized Information Flows in Grocery Distribution. Licentiatavhandling 1184, IDA-EIS, Universitetet och Tekniska Högskolan i Linköping.

46. Kollberg, Maria, 2005, Beyond IT and Productivity - Effects of Digitized Information Flows in the Logging Industry. Licentiatavhandling 1185, IDA-EIS, Universitetet och Tekniska Högskolan i Linköping.

47. Käll, Andreas, 2005, Översättningar av en managementmodell - En studie av införandet av Balanced Scorecard i ett landsting. Licentiatavhandling 1209, IDAEIS, Universitetet och Tekniska Högskolan i Linköping.

48. Mihailescu, Daniella, 2006, Implementation Methodology in Action - A Study of an Enterprise Systems Implementation Methodology. Licentiatavhandling 1233, IDA-EIS, Universitetet och Tekniska Högskolan i Linköping.

49. Park-Westman, Misook, 2006, Managing Competence Development Programs in a Cross-cultural Organisation - What are the Barriers and Enablers? Licentiatavhandling 1263, IDA-EIS, Universitetet och Tekniska Högskolan i Linköping.

50. Flodström, Raquel, 2006, A Framework for the Strategic Management of Information Technology. Licentiatavhandling 1272, IDA-EIS, Universitetet och Tekniska Högskolan i Linköping.

51. Fryk, Pontus, 2007, Beyond IT and Productivity - Effects of Digitized Information Flows in Health Care. Licentiatavhandling 1328, IEI-EIS, Universitetet och Tekniska Högskolan i Linköping.

52. Lundmark, Erik, 2008, Organisational Adoption of Innovations - Management Practices and IT. Licentiatavhandling 1352, IEI-EIS, Universitetet och Tekniska Högskolan i Linköping. 
53. Anjou, Annette, 2008, Scanias framgång - Betydelsen av strategisk kongruens och integrerad styrning. Licentiatavhandling 1364, IEI-EIS, Universitetet och Tekniska Högskolan i Linköping.

54. Fagerberg, Jesper, 2008, Occupational Fraud-Auditors' Perceptions of Red Flags and Internal Control. Licentiatavhandling 1369, IEI-EIS, Universitetet och Tekniska Högskolan i Linköping.

55. Arwinge, Olof, 2010, Internal Control - A Study of the Concept and Themes of Internal Control. Licentiatavhandling 1431, IEI-EIS, Universitetet och Tekniska Högskolan i Linköping.

56. Svensson, Martin, 2010, Routines for Engagement-Emotions and Routines when Communicating through ICTs. Licentiatavhandling 1444, IEI-EIS, Universitetet och Tekniska Högskolan i Linköping.

57. Gullberg, Cecilia, 2011, Puzzle or Mosaic? On Managerial Information Patterns. Licentiatavhandling 1483, IEI-EIS, Universitetet och Tekniska Högskolan i Linköping.

58. Styf, Elisabeth, 2011, Styrelsens ansvar för den interna koden. Licentiatavhandling 1491, IEI-EIS, Universitetet och Tekniska Högskolan i Linköping.

59. Granath, Malin, 2012, Kan professioner organiseras fram? - En fallstudie av den kommunala energi- och klimatrådgivningen. Licentiatavhandling 1519, IEI-EIS, Universitetet och Tekniska Högskolan i Linköping.

60. Eriksson, Emelie, 2017, Patterns of corporate visual self-representations in accounting narratives. Licentiatavhandling 1792, IEI-EIS, Universitetet och Tekniska Högskolan i Linköping.

61. Lindeberg, Fredrik, 2019, Coordinating the Internet, Licentiatavhandling 1862, IEI-EIS, Universitetet och Tekniska Högskolan i Linköping. 



\section{The Swedish Research School of Management and Information Technology MIT}

The Swedish Research School of Management and Information Technology (MIT) is one of 16 national research schools supported by the Swedish Government. MIT is jointly operated by the following institutions: Blekinge Institute of Technology, Chalmers University of Technology, University of Gothenburg, Jönköping International Business School, Karlstad University, Linköping University, Linnaeus University Växjö, Lund University, Mälardalen University College, Stockholm University, Umeå University, Örebro University, and Uppsala University, host to the research school. At the Swedish Research School of Management and Information Technology (MIT), research is conducted, and doctoral education provided, in three fields: management information systems, business administration, and informatics.

\section{DISSERTATIONS FROM THE SWEDISH RESEARCH SCHOOL OF MANAGEMENT AND INFORMATION TECHNOLOGY}

\section{Doctoral theses (2003- )}

1. Baraldi, Enrico (2003), When Information Technology Faces Resource Interaction: Using IT Tools to Handle Products at IKEA and Edsbyn. Department of Business Studies, Uppsala University, Doctoral Thesis No. 105.

2. Wang, Zhiping (2004), Capacity-Constrained Production-Inventory Systems: Modelling and Analysis in both a Traditional and an E-Business Context. IDA-EIS, Linköpings universitet och Tekniska Högskolan i Linköping, Dissertation No. 889

3. Ekman, Peter (2006), Enterprise Systems \& Business Relationships: The Utilization of IT in the Business with Customers and Suppliers. School of Business, Mälardalen University, Doctoral Dissertation No 29.

4. Lindh, Cecilia (2006), Business Relationships and Integration of Information Technology. School of Business, Mälardalen University, Doctoral Dissertation No 28.

5. Frimanson, Lars (2006), Management Accounting and Business Relationships from a Supplier Perspective. Department of Business Studies, Uppsala University, Doctoral Thesis No. 119.

6. Johansson, Niklas (2007), Self-Service Recovery. Information Systems, Faculty of Economic Sciences, Communication and IT, Karlstad University, Dissertation KUS 2006:68.

7. Sonesson, Olle (2007), Tjänsteutveckling med personal medverkan: En studie av banktjänster. Företagsekonomi, Fakulteten för ekonomi, kommunikation och IT, Karlstads universitet, Doktorsavhandling, Karlstad University Studies 2007:9. 
8. Maaninen-Olsson, Eva (2007), Projekt $i$ tid och rum: Kunskapsintegrering mellan projektet och dess historiska och organisatoriska kontext. Företagsekonomiska institutionen, Uppsala universitet, Doctoral Thesis No. 126.

9. Keller, Christina (2007), Virtual learning environments in higher education: A study of user acceptance. Linköping Studies in Science and Technology, Dissertation No. 1114.

10. Abelli, Björn (2007), On Stage! Playwriting, Directing and Enacting the Informing Processes. School of Business, Mälardalen University, Doctoral Dissertation No. 46.

11. Cöster, Mathias (2007), The Digital Transformation of the Swedish Graphic Industry. Linköping Studies in Science and Technology, Linköping University, Dissertation No. 1126.

12. Dahlin, Peter (2007), Turbulence in Business Networks: A Longitudinal Study of Mergers, Acquisitions and Bankruptcies Involving Swedish IT-companies. School of Business, Mälardalen University, Doctoral Thesis No. 53.

13. Myreteg, Gunilla (2007), Förändringens vindar: En studie om aktörsgrupper och konsten att välja och införa ett affärssystem. Företagsekonomiska institutionen, Uppsala universitet, Doctoral Thesis No. 131.

14. Hrastinski, Stefan (2007), Participating in Synchronous Online Education. School of Economics and Management, Lund University, Lund Studies in Informatics No. 6.

15. Granebring, Annika (2007), Service-Oriented Architecture: An Innovation Process Perspective. School of Business, Mälardalen University, Doctoral Thesis No. 51.

16. Lövstål, Eva (2008), Management Control Systems in Entrepreneurial Organizations: A Balancing Challenge. Jönköping International Business School, Jönköping University, JIBS Dissertation Series No. 045.

17. Hansson, Magnus (2008), On Closedowns: Towards a Pattern of Explanation to the Closedown Effect. Örebro University School of Business, Örebro University, Doctoral Thesis No. 1.

18. Fridriksson, Helgi-Valur (2008), Learning processes in an inter-organizational context: A study of krAft project. Jönköping International Business School, Jönköping University, JIBS Dissertation Series No. 046.

19. Selander, Lisen (2008), Call Me Call Me for some Overtime: On Organizational Consequences of System Changes. Institute of Economic Research, Lund Studies in Economics and Management No. 99.

20. Henningsson, Stefan (2008), Managing Information Systems Integration in Corporate Mergers \& Acquisitions. Institute of Economic Research, Lund Studies in Economics and Management No. 101.

21. Ahlström, Petter (2008), Strategier och styrsystem för seniorboende-marknaden. IEI-EIS, Linköping universitetet och Tekniska Högskolan i Linköping, Doktorsavhandling, Nr. 1188.

22. Sörhammar, David (2008), Consumer-firm business relationship and network: The case of "Store" versus Internet. Department of Business Studies, Uppsala University, Doctoral Thesis No. 137. 
23. Caesarius, Leon Michael (2008), In Search of Known Unknowns: An Empirical Investigation of the Peripety of a Knowledge Management System. Department of Business Studies, Uppsala University, Doctoral Thesis No. 139.

24. Cederström, Carl (2009), The Other Side of Technology: Lacan and the Desire for the Purity of Non-Being. Institute of Economic Research, Lund University, Doctoral Thesis, ISBN: 9185113-37-9.

25. Fryk, Pontus, (2009), Modern Perspectives on the Digital Economy: With Insights from the Health Care Sector. Department of Business Studies, Uppsala University, Doctoral Thesis No. 145.

26. Wingkvist, Anna (2009), Understanding Scalability and Sustainability in Mobile Learning: A Systems Development Framework. School of Mathematics and Systems Engineering, Växjö University, Acta Wexionesia, No. 192, ISBN: 978-91-7636-687-5.

27. Sällberg, Henrik (2010), Customer Rewards Programs: Designing Incentives for Repeated Purchase. Blekinge Institute of Technology, School of Management, Doctoral Dissertation Series No. 2010:01.

28. Verma, Sanjay (2010), New Product Newness and Benefits: A Study of Software Products from the Firms' Perspective. Mälardalen University Press, Doctoral Thesis.

29. Iveroth, Einar (2010), Leading IT-Enabled Change Inside Ericsson: A Transformation Into a Global Network of Shared Service Centres. Department of Business Studies, Uppsala University, Doctoral Thesis No. 146.

30. Nilsson, Erik (2010), Strategi, styrning och konkurrenskraft: En longitudinell studie av Saab AB. IEI-EIS, Linköpings universitet och Tekniska Högskolan i Linköping, Doktorsavhandling, Nr. 1318.

31. Sjöström, Jonas (2010), Designing Information Systems: A pragmatic account. Department of Informatics and Media, Uppsala University, Doctoral Thesis.

32. Numminen, Emil (2010), On the Economic Return of a Software Investment: Managing Cost, Benefit and Uncertainty. Blekinge Institute of Technology, School of Management, Doctoral Thesis.

33. Frisk, Elisabeth (2011), Evaluating as Designing: Towards a Balanced IT Investment Approach. IT University, Göteborg, Doctoral Thesis.

34. Karlsudd, Peter (2011), Support for Learning: Possibilities and Obstacles in Learning Applications. Mälardalen University, Doctoral Thesis.

35. Wicander, Gudrun (2011), Mobile Supported e-Government Systems: Analysis of the Education Management Information System (EMIS) in Tanzania. Karlstad University, Doctoral Thesis. Karlstad University Studies 2011:49.

36. Åkesson, Maria (2011), Role Constellations in Value Co-Creation: A Study of Resource Integration in an e-Government Context. Karlstad University, Doctoral Thesis. Karlstad University Studies 2011:36. 
37. Nfuka, Edephonce N. (2012), IT Governance in Tanzanian Public Sector Organisations. Department of Computer and Systems Sciences, Stockholm University, Doctoral Thesis.

38. Larsson, Anders Olof (2012), Doing Things in Relation to Machines: Studies on Online Interactivity. Department of Informatics and Media, Uppsala University, Doctoral Thesis.

39. Andersson, Bo (2012), Harnessing Handheld Computing: Framework, Toolkit and Design Propositions. Lund University, Doctoral Thesis.

40. Erixon, Cecilia (2012), Information System Providers and Business Relationships: A Study on the Impact of Connections. Mälardalen University, Doctoral Thesis.

41. Svensson, Martin (2012), Routes, Routines and Emotions in Decision Making of Emergency Call Takers. Blekinge Institute of Technology, Doctoral Dissertation Series No. 2012:04.

42. Svensson, Ann (2012), Kunskapsintegrering med informationssystem I professionsorienterade praktiker. Institutionen för tillämpad IT, Göteborgs universitet, Doktorsavhandling.

43. Pareigis, Jörg (2012), Customer Experiences of Resource Integration: Reframing Servicescapes Using Scripts and Practices. Karlstad University, Doctoral Thesis. Karlstad University Studies 2012:38.

44. Röndell, Jimmie (2012), From Marketing to, to Marketing with Consumers. Department of Business Studies, Uppsala University, Doctoral Thesis No. 155.

45. Lippert, Marcus (2013), Communities in the Digital Age: Towards a Theoretical Model of Communities of Practice and Information Technology. Department of Business Studies, Uppsala University, Doctoral Thesis No. 156.

46. Netz, Joakim (2013), Diffusa spänningar eller spännande tillväxt? Företagsledning i tider av snabb förändring. Mälardalens högskola, Doktorsavhandling nr 135.

47. Thorén, Claes (2013), Print or Perish? A Study of Inertia in a Regional Newspaper Industry. Karlstad University, Doctoral Thesis. Karlstad University Studies 2014:10 (Ny uppl.).

Stockhult, Helén (2013), Medarbetare $i$ dialog: en studie om viljan att göra mer än det formellt förväntade. Örebro universitet, Örebro Studies in Business Dissertations, 4.

48. Mihailescu, Daniela (2013), Explaining the Use of Implementation Methodology in Enterprise Systems Implementation Context: A Critical Realist Perspective. Lund University, Doctoral Thesis.

49. Ghazawneh, Ahmad (2012), Towards a Boundary Resources Theory of Software Platforms. Jönköping International Business School, Doctoral Thesis.

50. Shams, Poja (2013), What Does it Take to Get your Attention? The Influence of In-Store and Out-of-Store Factors on Visual Attention and Decision Making for Fast-Moving Consumer Goods. Karlstad University, Doctoral Thesis. Karlstad University Studies 2013:5.

51. Osowski, Dariusz (2013), From Illusiveness to Genuineness: Routines, Trading Zones, Tools and Emotions in Sales Work. Department of Business Studies, Uppsala University, Doctoral Thesis No. 160. 
52. Höglund, Linda (2013), Discursive Practises in Strategic Entrepreneurship: Discourses and Repertoires in Two Firms. Örebro University, Doctoral Thesis.

53. Persson Ridell, Oscar (2013), Who is the Active Consumer? Insight into Contemporary Innovation and Marketing Practices. Department of Business Studies, Uppsala University, Doctoral Thesis.

54. Kask, Johan (2013), On business relationships as Darwinian systems: An exploration into how Darwinian systems thinking can support business relationship research. Örebro University, Doctoral Thesis.

55. Paulsson, Wipawee Victoria (2013), The Complementary Use of IS Technologies to Support Flexibility and Integration Needs in Budgeting. Lund University, Doctoral Thesis.

56. Kajtazi, Miranda (2013), Assessing Escalation of Commitment as an Antecedent of Noncompliance with Information Security Policy. Linnaeus University, Doctoral Thesis.

57. Hasche, Nina (2013), Value Co-Creating Processes in International Business Relationships: Three empirical stories of co-operation between Chinese customers and Swedish suppliers. Örebro University, Doctoral Thesis.

58. Pierce, Paul (2013), Using Alliances to Increase ICT Capabilities. Lund University, Doctoral Thesis.

59. Mansour, Osama (2013), The Bureaucracy of Social Media: An Empirical Account in Organizations. Linnaeus University, Doctoral Thesis.

60. Osmonalieva, Zarina (2013), Factors Determining Exploitation of Innovative Venture Ideas: A study of nascent entrepreneurs in an advisory system. Mälardalen University, Doctoral Thesis.

61. Holmberg, Nicklas (2014), The Purity of Separation of Concerns: The Service Oriented Business Process - a Design Approach for Business Agility. Lund University, Doctoral Thesis.

62. Poth, Susanna (2014), Competitive Advantage in the Service Industry. The Importance of Strategic Congruence, Integrated Control and Coherent Organisational Structure: A Longitudinal Case Study of an Insurance Company. Department of Business Studies, Uppsala University, Doctoral Thesis.

63. Safari, Aswo (2014), Consumer Foreign Online Purchasing: Uncertainty in the ConsumerRetailer Relationship. Department of Business Studies, Uppsala University, Doctoral Thesis.

64. Sandberg, Johan (2014), Digital Capability: Investigating Coevolution of IT and Business Strategies. Umeå University, Doctoral Thesis.

65. Eklinder Frick, Jens (2014), Sowing Seeds for Innovation: The Impact of Social Capital in Regional Strategic Networks. Mälardalen University, Doctoral Thesis.

66. Löfberg, Nina (2014), Service Orientation in Manufacturing Firms: Understanding Challenges with Service Business Logic. Karlstad University, Doctoral Thesis. Karlstad University Studies 2014:30. 
67. Gullberg, Cecilia (2014), Roles of Accounting Information in Managerial Work. Department of Business Studies, Uppsala University, Doctoral Thesis No. 171.

68. Bergkvist, Linda (2014), Towards a Framework for Relational-Oriented Management of Information Systems Outsourcing: Key Conditions Connected to Actors, Relationships and Process. Karlstad University, Doctoral Thesis. Karlstad University Studies 2014:31.

69. Tavassoli, Sam (2014), Determinants and Effects of Innovation: Context Matters. Blekinge Institute of Technology, Doctoral Thesis No. 2014:10.

70. Högström, Claes (2014), Fit In to Stand Out: An Experience Perspective on Value Creation. Karlstad University, Doctoral Thesis. Karlstad University Studies 2014:44.

71. Jansson, Tomas (2015), Agila projektledningsmetoder och motivation. Karlstads universitet, Doctoral Thesis. Karlstad University Studies 2015:9.

72. Ryzhkova, Natalia (2015), Web-Enabled Customer Involvement: A Firms' Perspective. Blekinge Institute of Technology, Doctoral Thesis.

73. Sundberg, Klas (2015), Strategisk utveckling och ekonomistyrning: Ett livscykelperspektiv. Företagsekonomiska institutionen, Uppsala universitet, Doctoral Thesis No. 173.

74. Nylén, Daniel (2015), Digital Innovation and Changing Identities: Investigating Organizational Implications of Digitalization. Umeå University, Doctoral Thesis.

75. Chowdhury, Soumitra (2015), Service Logic in Digitalized Product Platforms: A Study of Digital Service Innovation in the Vehicle Industry. Gothenburg University, Doctoral Thesis.

76. Jogmark, Marina (2015), Den regionala transformationsprocessens sociala dimension. Karlskrona 1989-2002. Blekinge Tekniska Högskola, Doctoral Thesis.

77. Sundström, Angelina (2015), Old Swedish Business in New International Clothes: Case Studies on the Management of Strategic Resources in Foreign-Acquired Swedish R\&D Firms. Mälardalen University, Doctoral Thesis.

78. Öbrand, Lars (2015), Information Infrastructure Risk: Perspectives, Practices \& Technologies. Umeå University, Doctoral Thesis.

79. Brozović, Danilo (2016), Service Provider Flexibility: A Strategic Perspective. Stockholm University, Doctoral Thesis.

80. Siegert, Steffi (2016), Enacting Boundaries through Social Technologies: A Dance between Work and Private Life. Stockholm University, Doctoral Thesis.

81. Linton, Gabriel (2016), Entrepreneurial Orientation: Reflections from a Contingency Perspective. Örebro University, Doctoral Thesis.

82. Akram, Asif (2016), Value Network Transformation: Digital Service Innovation in the Vehicle Industry. Department of Applied Information Technology, Chalmers University of Technology and University of Gothenburg, Doctoral Thesis. 
83. Hadjikhani, Annoch (2016), Executive Expectation in the Internationalization Process of Banks: The Study of Two Swedish Banks Foreign Activities. Department of Business Studies, Uppsala University, Doctoral Thesis No. 177.

84. El-Mekawy, Mohamed (2016), From Theory to Practice of Business-IT Alignment: Barriers, an Evaluation Framework and Relationships with Organizational Culture. DSV, Stockholm University, Doctoral Thesis.

85. Salavati, Sadaf (2016), Use of Digital Technologies in Education: The Complexity of Teachers' Everyday Practice. Linnaeus University, Doctoral Thesis.

86. Pashkevich, Natallia (2016), Information Worker Productivity Enabled by IT System Usage: A Complementary-Based Approach. Stockholm Business School, Stockholm University, Doctoral Thesis.

87. Stone, Trudy-Ann (2016), Firms in Global Value Chains. Blekinge Institute of Technology (BTH), Doctoral Thesis.

88. Saarikko, Ted (2016), An Inquiry into the Nature and Causes of Digital Platforms. Umeå University, Doctoral Thesis.

89. Tona, Olgerta (2017), The Journey of Mobile Business Intelligence: From Vision to Use. Lund University, Doctoral Thesis.

90. Fredin, Sabrina (2017), History and Geography Matter: The Cultural Dimension of Entrepreneurship. Blekinge Institute of Technology, Doctoral Thesis.

91. Giovacchini, Elia (2017), Weaving the Symbiotic Relationship: A Longitudinal Study of a Firm-Sponsored Open Source Community Relationship Maintenance. Stockholm Business School, Stockholm University, Doctoral Thesis.

92. Gillmore, Edward (2017), Four Essays on Subsidiary Evolution: Exploring the Antecedents, Contexts and Outcomes of Mandate Loss. School of Business, Mälardalen University, Doctoral Thesis.

93. Crawford, Jason (2017), Regulation's Influence on Risk Management and Management Control Systems in Banks. Department of Business Studies, Uppsala University, Doctoral Thesis.

94. Von Schantz, Hanna (2017), Well, that makes sense! Investigating opportunity development in a technology start-up. Stockholm Business School, Stockholm University, Doctoral Thesis.

95. Wass, Sofie (2017), The Importance of eHealth Innovations: Lessons about Patient Accessible Information. Jönköping International Business School, Doctoral Thesis.

96. Imre, Özgün (2018), Adopting Information Systems: Perspectives from Small Organizations. Department of Management and Engineering (IEI), Linköping University, Doctoral Thesis.

97. Lövgren, Daniel (2017), Dancing Together Alone: Inconsistencies and Contradictions of Strategic Communication in Swedish Universities. Informatics and Media, Uppsala University, Doctoral Thesis. 
98. Charitsis, Vasileios (2018), Self-Tracking, Datafication and the Biopolitical Prosumption of Life. Karlstad University, Doctoral Thesis.

99. Lammi, Inti (2018), A Practice Theory in Practice: Analytical Consequences in the Study of Organization and Socio-Technical Change. Department of Business Studies, Uppsala University, Doctoral Thesis.

100. Leite, Emilene (2018), Complexity in the 'Extended' Business Network: A study of Business, Social and Political Relationships in Smart City Solutions. Department of Business Studies, Uppsala University, Doctoral Thesis.

101. Aasi, Parisa (2018), Information Technology Governance: The Role of Organizational Culture and Structure. Department of Computer and Systems Sciences, Stockholm University, Doctoral Thesis.

102. Servadio, Luigi (2018), Customer Rituals: Ethnographic Explorations of Wine Rituals with Families and Friends. Stockholm Business School, Stockholm University, Doctoral Thesis.

103. Ahlgren, Kajsa (2018), Travelling Business Models: On Adapting Business Models to New Contexts. Design Sciences, Faculty of Engineering, Lund University, Doctoral Thesis.

104. Markowski, Peter (2018), Collaboration Routines: A Study of Interdisciplinary Healthcare. Stockholm Business School, Stockholm University, Doctoral Thesis.

105.Zaffar, Fahd Omair (2018), The Value of Social Media: What Social Networking Sites Afford Organizations. Division of Informatics, Department of Applied Information Technology, University of Gothenburg, Doctoral Thesis.

106. Stendahl, Emma (2018), Headquarters Involvement in Managing Subsidiaries. Stockholm Business School, Stockholm University, Doctoral Thesis.

107. Fischer, Christian (2018), Business Intelligence through a Sociomaterial Lens: The Imbrication of People and Technology in a Sales Process. Department of Business Studies, Uppsala University, Doctoral Thesis.

108. Lagin, Madelen (2018), The Price We Pay: The Autonomy of Store Managers in Making Price Decisions. Department of Business Studies, Örebro University, Doctoral Thesis.

109. Odar, Susanne (2019), Managementinitiativ, mening och verksamhetsresultat: En retrospektiv studie av en teknikintensiv verksamhet. Department of Management and Engineering (IEI), Linköping University, Linköping Studies in Science and Technology, Doctoral Thesis.

110. Radits, Markus (2019), A Business Ecology Perspective on Community-Driven Open Source: The Case of the Free and Open Source Content Management System Joomla. Department of Management and Engineering (IEI), Linköping University, Linköping Studies in Science and Technology, Doctoral Thesis No. 1937.

111. Skog, Daniel A. (2019), The Dynamics of Digital Transformation: The Role of Digital Innovation, Ecosystems and Logics in Fundamental Organizational Change. Umeå University, Doctoral Thesis. 
112. Ek, Peter (2019), Managing Digital Open Innovation with User Communities: A Study of Community Sensing and Product Openness Capabilities in the Video Game Industry. Department of Business Studies, Uppsala University, Doctoral Thesis No. 199

113. Muhic, Mirella (2019), Transition to Cloud sourcing - Innovation and competitive advantage. Design Sciences, Faculty of Engineering, Lund University, Doctoral Thesis.

114. Mankevich, Vasili (2019), Digital Innovation Management: Investigating Digital Trace Data in Online Communities. Umeå University, Doctoral Thesis.

115. Vink, Josina (2019), In/visible - Conceptualizing Service Ecosystem Design. Karlstad University, Doctoral Thesis.

116. Bäckström, Izabelle (2019), Mirror, mirror on the wall, who's the innovator after all? An explorative study of a management-initiated employee innovation process.

Department of Design Sciences, Faculty of Engineering, Lund University, Doctoral Thesis No. 116.

117. Bani-Hani, Imad (2020), Self-Service Business Analytics and the Path to Insights: Integrating Resources for Generating Insights, Department of Informatics, School of Economics and Management, Lund University.

118. Kashyap, Shruti Rangan (2020), Monsoon Paper Dragons: Transparency, Accountability, Risk, and Compliance in Banking Regulation and Practice, Department of Business Studies, Uppsala University, Doctoral Thesis.

119. Havemo, Emelie (2020), Den visuella bilden av organisationen: Perspektiv på visualitet $i$ accounting, Linköping Studies in Science and Technology, Doktorsavhandling nr. 2075. Institutionen för ekonomisk och industriell utveckling, Linköpings universitet. 


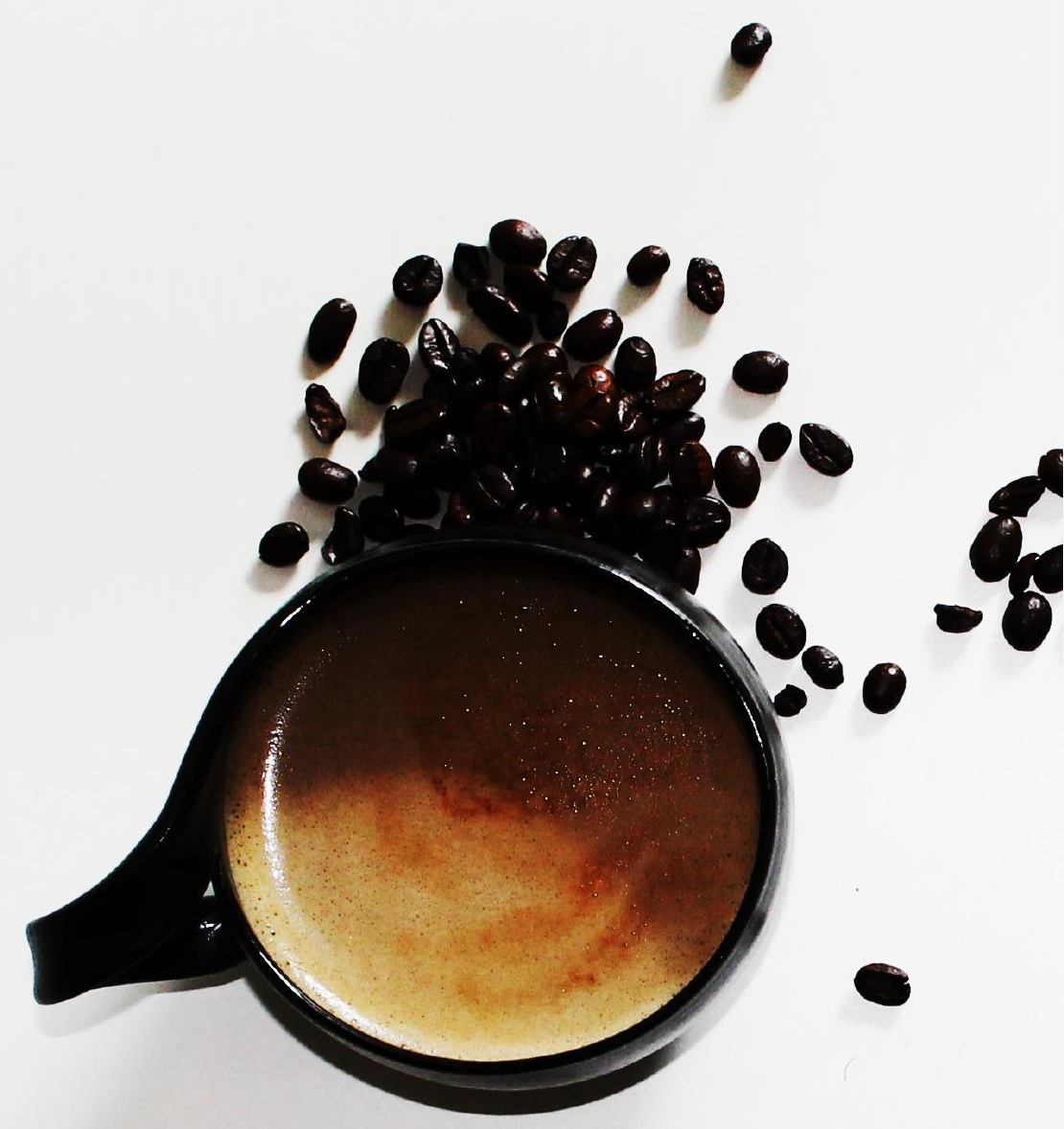

\section{TEKNISKA FAKULTETEN}

Linköping Studies in Science and Technology,

Avhandling Nr. 2075

Institutionen för ekonomisk och industriell utveckling

Linköpings universitet

58183 Linköping

www.liu.se

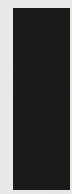

